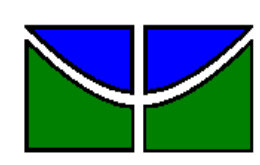

Universidade de Brasília

Faculdade de Economia, Administração e Contabilidade - FACE Programa de Pós-Graduação em Administração - PPGA

Relações entre Compartilhamento de Conhecimento Organizacional e Ações de Gestão de Conhecimento na Administração Direta Federal.

Fábio Ferreira Silva

Brasília - DF 
Universidade de Brasília

Faculdade de Economia, Administração e Contabilidade - FACE

Programa de Pós-Graduação em Administração - PPGA

Fábio Ferreira Silva

Relações entre Compartilhamento de Conhecimento

Organizacional e Ações de Gestão de Conhecimento na Administração Direta Federal.

Dissertação apresentada ao Programa de Pós-Graduação em Administração da Universidade de Brasília (PPGA/UnB), como requisito parcial à obtenção do título de Mestre em Administração.

Professora Orientadora: Prof. Dra. Catarina Cecília Odelius

Brasília - DF 
Fábio Ferreira Silva

\section{Relações entre Compartilhamento de Conhecimento Organizacional e Ações de Gestão de Conhecimento na Administração Direta Federal.}

Esta dissertação foi examinada pela seguinte banca examinadora:

Professora Dra. CATARINA CECÍLIA ODELIUS

Universidade de Brasília (UnB)

Professor Dr. ANTÔNIO ISIDRO DA SILVA FILHO

Universidade de Brasília (UnB)

Professora Dra. HELGA CRISTINA HEDLER

Universidade Católica de Brasília (UCB)

Brasília - DF 
Dedicatória

Dedico este trabalho aos meus amados filhos, Guilherme e Beatriz. 


\section{Agradecimentos}

Em primeiro lugar agradeço à minha esposa, Juliana Costa. Compor uma família com uma pessoa que cria diversos objetivos durante a vida nunca não é uma tarefa fácil: voos, mudança, viagens, filhos e Mestrado. Os últimos anos foram movimentados, mas sem você não teria sido possível, nem tão pouco teria feito qualquer sentido. Suas ideias, críticas e posicionamentos sempre foram bem vindos. Seu amor, atenção e compreensão estarão sempre refletidos nessas páginas.

Agradeço aos meus filhos, Guilherme e Beatriz. Um Homem que estabelece como objetivo exercer a paternidade em sua completude carrega consigo muitos afazeres e, raramente, dispõe de tempo para realizar todas as suas tarefas. Mas esse tipo de gente só é feliz assim: cercado dos filhos e das atividades que levam alegria e ludicidade às crianças. Por isso agradeço aos meus filhos por terem sido minha fonte de inspiração e pelas demonstrações de carinho durante essa jornada. A maneira simples de enxergar a vida e o sorriso de vocês torna qualquer missão mais fácil.

A toda minha família meus sinceros agradecimentos. Nicinha, minha irmã, muito obrigado pelo seu amor, compreensão e apoio incondicionais. Hoje nossa família é maior, de forma que sempre lembro com muito carinho do convívio com Carlos José, meu cunhado, e meus sobrinhos, Taís e Bernardo. Sempre soube que poderia contar com vocês.

Minha avó, meus tios e primos. Todos foram fundamentais para a minha formação desde que as dificuldades se apresentaram quando ainda era menino.

Aos meus amigos mais próximos, meu muito obrigado! Destaco a atuação da minha amiga Mariana Tunala por ocasião da coleta de dados nos diversos Ministérios que compuseram a amostra. Mais do que o fato de ter me ajudado, guardarei as lembranças da sua compreensão e preocupação com as causas do próximo.

Contudo, se chego ao final desse trabalho foi por que fui carregado nos ombros de gigantes. Agradeço aos companheiros da Comissão Coordenadora do Programa Aeronave de Combate (COPAC), em especial os amigos Júlio Tavares, Anderson Moreira e Otília Madalena, pela compreensão, incentivo e apoio, desde os meus primeiros passos naquela Comissão.

Aos meus Professores do PPGA, os meus mais profundos agradecimentos. Cultivei grandes momentos e ensinamentos com todos os Professores que tive na vida. Na UnB não foi diferente. Muitas foram as conversas e reflexões que surgiram da simples convivência com os Professores 
Tomas de Aquino, Carlos Denner, Pedro Menezes, Gisela Demo e Francisco Coelho. Muito obrigado por me ajudarem a enxergar os aspectos organizacionais de forma simples e lúcida. Aos Professores Isidro, da UnB, Mírian Oliveira, da PUC-RS, e Helga Hedler, da UCB, meus agradecimentos pela boa vontade e precisão na atuação como avaliadores do meu trabalho. As considerações e sugestões sobre o meu trabalho foram essenciais para que a investigação se tornasse mais consistentes em relação aos aspectos teóricos e metodológicos admitidos. Muito obrigado!

Aos meus colegas do PPGA, mestrandos e doutorandos, reservo um carinho especial pela excelente convivência e companheirismo. Sem qualquer dúvida, as melhores aulas que presenciei foram conduzidas por vocês. Aulas de perseverança, vontade, bom humor e principalmente esperança. Estaremos sempre ligados de alguma forma.

Com se pudesse personificar um prédio ou uma estrutura material, registro os meus agradecimentos à escola pública. Tive o privilégio de estudar em escolas municipais, estaduais e federais (civis e militares) e sempre encontrei ambientes com todas as dificuldades que permeiam as organizações públicas, mas sem nunca faltar comprometimento, vontade e interesse de professores e alunos, em uma atmosfera que dificilmente não produz grandes resultados.

À minha Professora e Orientadora, Catarina Odelius, qualquer tipo de agradecimento não será o suficiente. O que um Professor faz pelo seu aluno muitas vezes não é passível de mensuração. Mais do que corrigir textos, ajudar na organização de pensamentos perdidos e indicar leituras, um Orientador abraça a ideia do seu aluno, auxiliando-o na procura de um caminho viável para a condução da pesquisa. Nossas conversas e discussões fizeram com que eu me tornasse uma pessoa ainda mais reflexiva, crítica e atenta aos meandros organizacionais. Lembrar-me-ei de forma especial do seu zelo e dedicação nesses anos que convivemos na UnB. Muito obrigado por tentar extrair o melhor de mim nos diversos trabalhos que fizemos juntos!

Por fim, de forma emocionada, agradeço aos meus pais, Genário e Eunice. As suas histórias de superação e perseverança na vida sempre se fizeram presentes em minha trajetória. Os comportamentos e exemplos como administradores públicos e cidadãos estão presentes em minha maneira de analisar os fenômenos sociais deste trabalho, bem como estarão em diversos outros questionamentos que ainda virão. Nunca me senti sozinho em minhas madrugas. De corpo presente, ou não, senti que estavam presentes de alguma forma. Muito obrigado! 


\section{Epígrafe}

"Há uma força motriz mais poderosa que o vapor, a eletricidade e a energia atômica: a vontade".

Albert Einstein 


\section{SUMÁRIO}

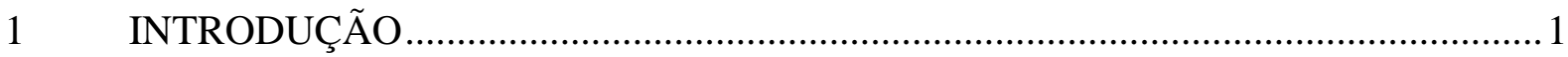

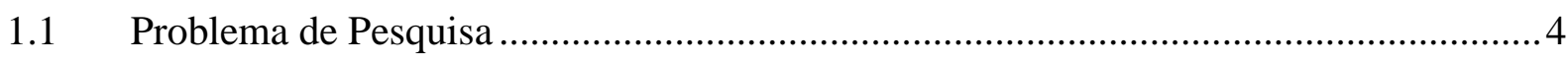

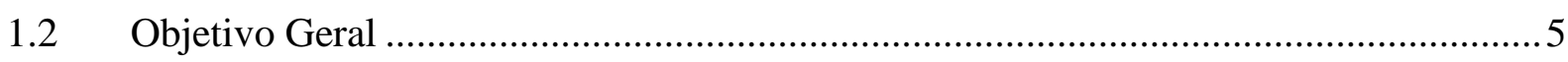

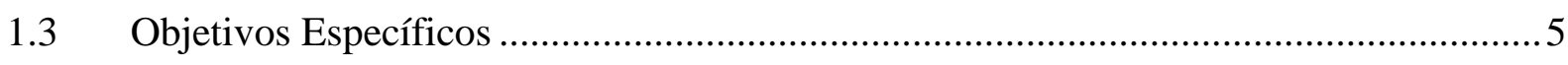

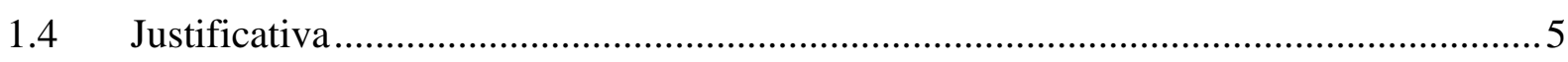

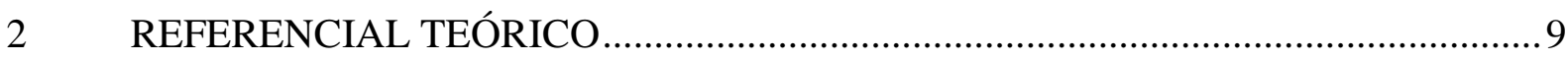

2.1 Conhecimento Organizacional: Evolução de Reflexões .........................................

2.2 Gestão do Conhecimento Organizacional..............................................................14

2.3 Compartilhamento do Conhecimento Organizacional ............................................. 21

2.4 Mecanismos de Aprendizagem e Compartilhamento do Conhecimento.......................41

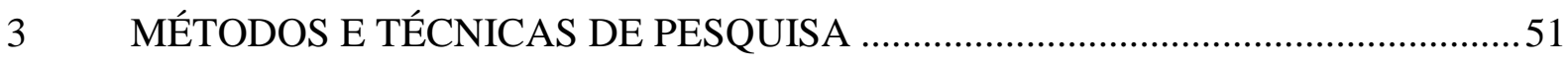

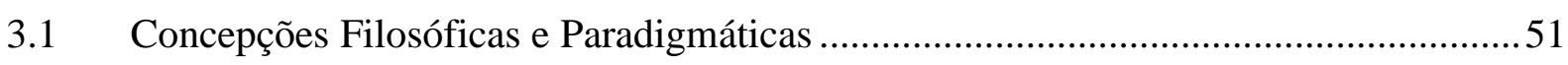

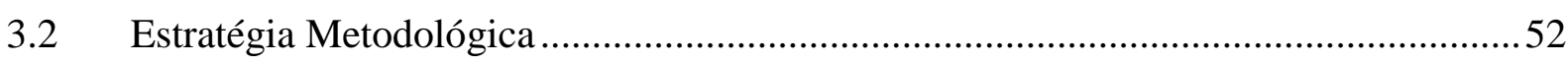

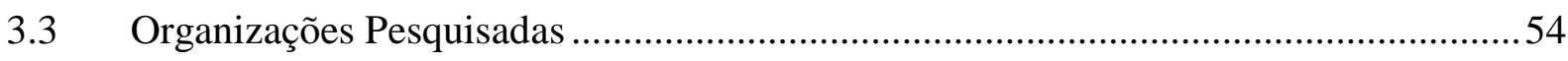

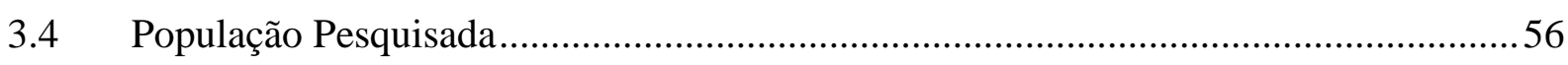

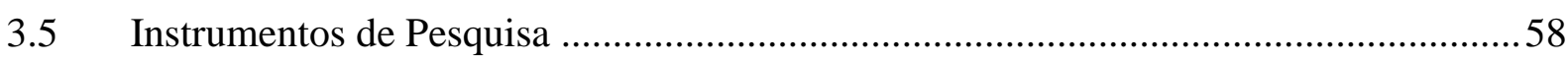

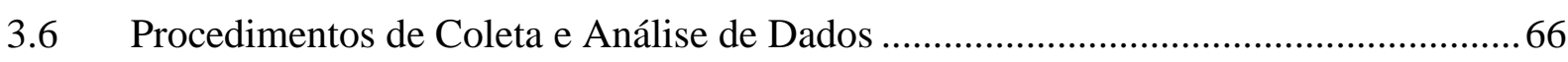

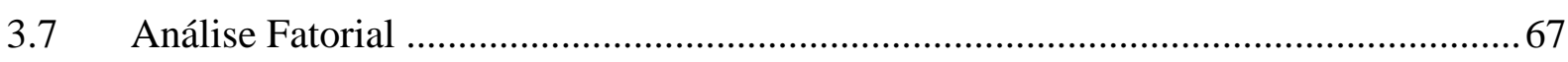

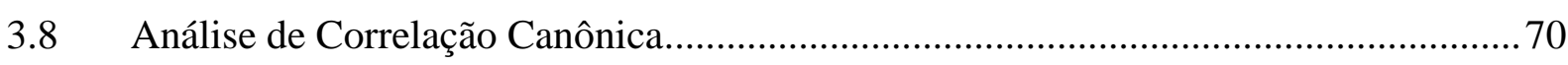

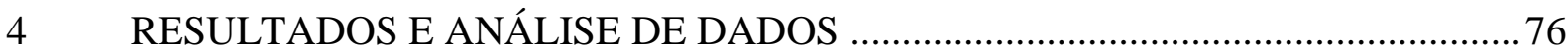

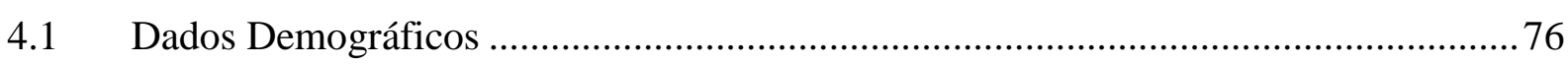

4.2 Escala de Mecanismos de Aprendizagem …...................................................... 78

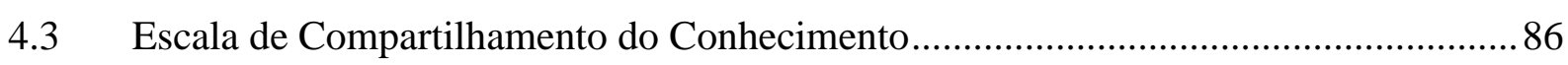

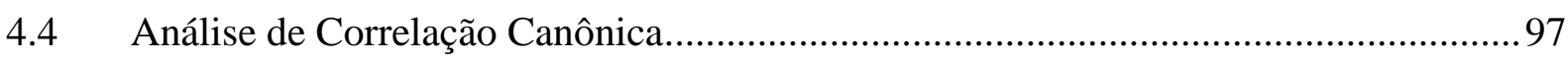

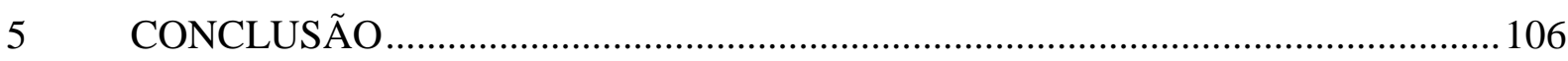

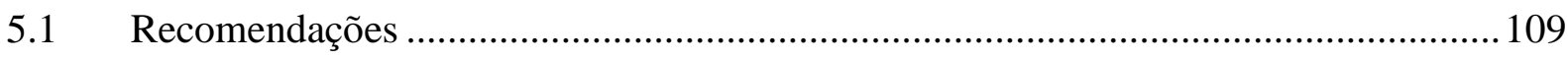

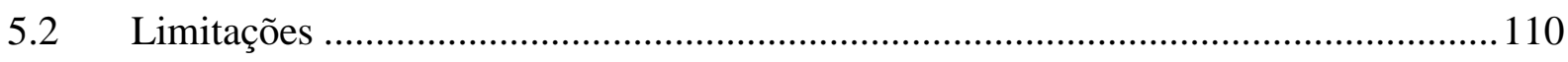

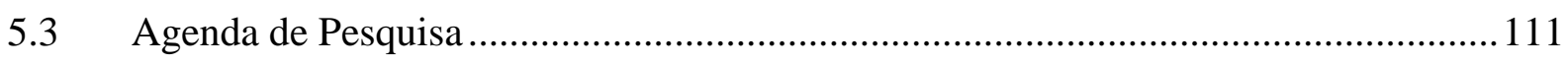

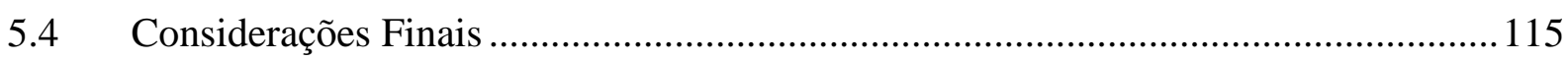

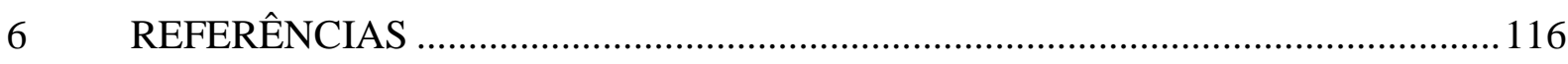

$7 \quad$ ANEXOS 


\section{Lista de Tabelas}

Tabela 1. Revisão conceitual 20

Tabela 2. Periódicos de Administração utilizados na pesquisa ...................................................21

Tabela 3. Demais periódicos utilizados na pesquisa ..............................................................22

Tabela 4. Síntese dos antecedentes do compartilhamento do conhecimento .............................29

Tabela 5. Síntese das capacidades de conhecimento organizacional ........................................ 44

Tabela 6. Síntese da população e da amostra pesquisada.......................................................57

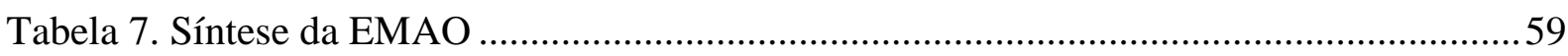

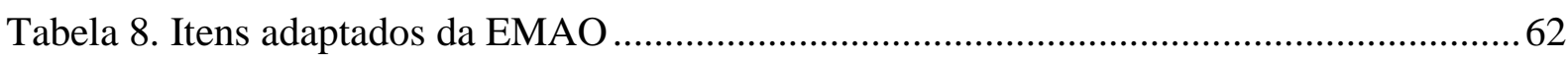

Tabela 9. Definições constitutiva e operacional sobre compartilhamento do conhecimento...64

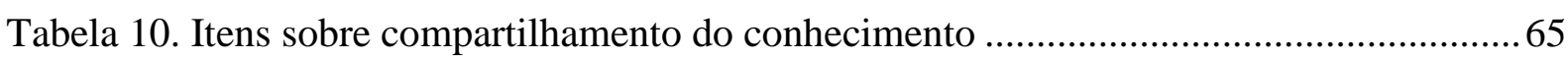

Tabela 11. Dados quanto ao sexo e idade da amostra pesquisada.............................................76

Tabela 12. Dados quanto ao nível de escolaridade e tempo na função ......................................77

Tabela 13. Fatorabilidade da escala de Mecanismos de Aprendizagem ...................................78

Tabela 14. Síntese da análise dos componentes principais da escala de Mecanismos de

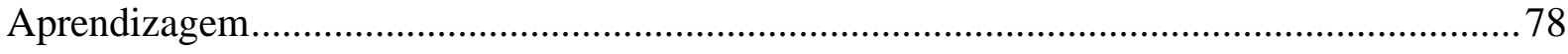

Tabela 15. Síntese do fator Mecanismos de Aquisiçao Interna.................................................. 81

Tabela 16. Síntese do fator Mecanismos de Codificação e Controle ............................................ 83

Tabela 17. Síntese do fator Mecanismos de Aquisição Externa................................................... 84

Tabela 18. Matriz de correlação de fator da escala de Mecanismos de Aprendizagem ............ 85

Tabela 19. Fatorabilidade da escala de Compartilhamento do Conhecimento............................87

Tabela 20. Síntese da análise dos componentes principais da escala de Compartilhamento do

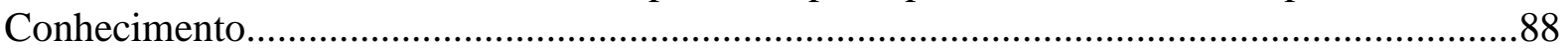

Tabela 21. Síntese do fator Absorção do Conhecimento........................................................... 89

Tabela 22. Síntese do fator Acesso ao Conehcimento.............................................................90

Tabela 23. Síntese do fator Interações Pessoais ....................................................................90

Tabela 24. Matriz de correlação de fator da escala de Compartilhamento do Conhecimento .96

Tabela 25. Teste multivariado de significância para as funções canônicas................................97

Tabela 26. Correlações canônicas e autovalores das funções canônicas.....................................98

Tabela 27. Teste multivariado de significância para as funções canônicas..................................98

Tabela 28. Correlações canônicas e autovalores da função canônica ........................................98

Tabela 29. Pesos canônicos padronizados das variáveis dependentes para a primeira função

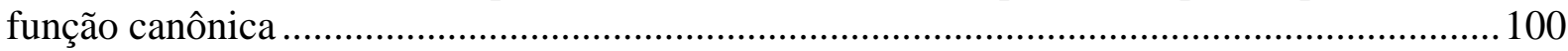

Tabela 30. Pesos canônicos padronizados das variáveis independentes para a primeira função função canônica

Tabela 31. Correlações entre variáveis dependentes e o grupo de variáveis canônicas "compartilhamento do conhecimento" - Primeira função canônica 
Tabela 32. Correlações entre variáveis independentes e o grupo de variáveis canônicas "mecanismos de aprendizagem" - Primeira função canônica ................................................ 102

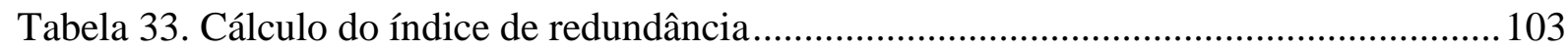




\section{Lista de Figuras}

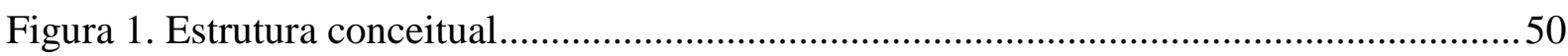

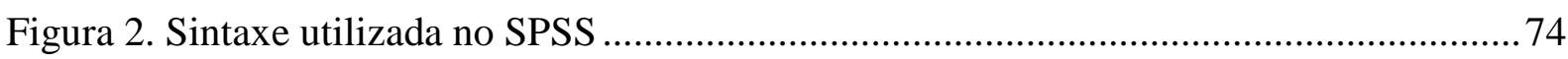

Figura 3. Gráfico scree plot da escala de Mecanismos de Aprendizagem .............................. 79

Figura 4. Gráfico scree plot da escala de Compartilhamento do Conhecimento .....................87

Figura 5. Esquema de correlação entre as variáveis "mecanismos de aprendizagem" e compartilhamento do conhecimento" 


\section{RESUMO}

O compartilhamento do conhecimento no ambiente organizacional é reconhecido pela comunidade acadêmica como sendo influenciado pelas ações de gestão de conhecimento, ou como também são denominadas, os mecanismos de aprendizagem. A existência de tal premissa ampara o objetivo deste estudo, qual seja identificar empiricamente a influência de mecanismos de aprendizagem proporcionados por organizações sobre o compartilhamento do conhecimento no ambiente organizacional. Para o alcance do objetivo foi desenvolvido um estudo de natureza quantitativa, no qual foi investigada uma amostra de 268 indivíduos de organizações civis e militares da Administração Direta Federal. O questionário utilizado nesta investigação foi composto pela Escala de Mecanismo de Aprendizagem em Organizações (EMAO), a qual foi adaptada por ocasião do presente estudo, além de uma escala sobre o compartilhamento do conhecimento, a qual foi desenvolvida no âmbito desta investigação. Após a realização da análise fatorial para ambas as escalas, procedeu-se uma análise de correlação canônica entre o grupo de variáveis associadas aos mecanismos de aprendizagem (variáveis independentes) e o grupo de variáveis sobre compartilhamento do conhecimento (variáveis dependentes). Os resultados encontrados na análise de correlação canônica indicam que os mecanismos de aprendizagem são responsáveis por explicar $35 \%$ da variância $\left(R^{2}=0,352\right)$ do grupo de variáveis sobre compartilhamento do conhecimento. Após a análise dos dados, conclui-se que as principais contribuições desta investigação foram (a) mensurar a intensidade da relação existente entre os mecanismos de aprendizagem e o compartilhamento do conhecimento e (b) testar o efeito preditivo dos mecanismos de aprendizagem sobre o compartilhamento do conhecimento.

Palavras-chave: Compartilhamento do Conhecimento; Gestão do Conhecimento; Mecanismos de Aprendizagem. 


\section{ABSTRACT}

The knowledge sharing in the organizational environment is recognized by the academic community as being influenced by knowledge management actions, or as they are also called, learning mechanisms. This premise supports the objective of this study, that is, empirically identify the influence between learning mechanisms provided by organizations for knowledge sharing over knowledge sharing in the organizational environment. To reach this goal it was developed a quantitative study in which were investigated a sample of 268 individuals from civil and military organizations in the Brazilian Federal Administration. The questionnaire used was composed of the Measurement Scale of Organizational, which was adapted during the present study, and a measurement scale of knowledge sharing, which was developed in this investigation. Upon completion of the factor analysis on both scales, it was proceeded a canonical correlation analysis between the group of variables associated to learning mechanisms (independent variables) and the group of knowledge sharing variables (dependent variables). The results found in the canonical correlation analysis indicate that learning mechanisms are responsible for explaining $35 \%$ of the variance $\left(R^{2}=0,352\right)$ for the group of knowledge sharing variables. After analyzing the data, it is concluded that the main contributions of this research were (a) measure the intensity of the relationship between the learning mechanisms and knowledge sharing and (b) testing the predictive effect of learning mechanisms over knowledge sharing.

Keywords: Knowledge Sharing; Knowledge Management; Learning Mechanisms. 


\section{INTRODUÇÃO}

A tarefa de desvendar os fenômenos que ocorrem no dinâmico contexto organizacional emerge como um grande desafio aos pesquisadores. A análise das múltiplas variáveis que coexistem no ambiente das organizações aponta um caminho viável para a compreensão da ação dos atores em seu ambiente de trabalho e na forma como esses mesmos atores negociam com as suas tensões no cotidiano organizacional (Hatch, 1997).

Senge (1993) defende que o debate a respeito das questões organizacionais tenha o conhecimento como protagonista, relegando a segundo plano outros aspectos do contexto organizacional, tais como a produção e o trabalho. Enquanto isso, Stewart (1998) emerge com o termo "capital intelectual", no qual o conhecimento desempenha o papel de principal ativo disponível nas organizações com vistas à obtenção e manutenção da vantagem competitiva.

Spender (1996) afirma que a mudança presenciada no campo organizacional proporcionou a transição da era industrial para a era da informação, na qual não há mais lugar para a concepção do gerente como criador das regras, pois detém o conhecimento, enquanto o empregado apenas segue suas determinações. Sob uma nova perspectiva, é necessário que a organização seja considerada como um emaranhado de subgrupos, nos quais o conhecimento é criado e compartilhado, surgindo individualmente ou em equipes, perpassando por todos os níveis da organização.

De forma convergente aos autores acima, Davenport e Prusak (1998), Dean e Gottschalk (2007) e Argote e Miron-Spektor (2011) continuam a valorizar o papel do conhecimento para a organização, no entanto, ressaltam que o conhecimento organizacional é constituído por uma mistura constante de experiências, valores e informações contextualizadas, que ao serem mesclados com a interpretação, julgamento e criatividade do sujeito, proporcionam a manifestação de mudanças cognitivas ou comportamentais, que podem abranger componentes 
tácitos e explícitos enraizados em uma variedade de repositórios, incluindo os próprios indivíduos, às rotinas e diversos outros sistemas de memória organizacional.

Contudo, Davenport e Prusak (1998) e He, Baruch e Lin (2014) ressaltam que a grande disponibilidade do conhecimento organizacional não garante a sua utilização pela organização. A maneira como muitas organizações se encontram dispersas e arranjadas proporcionam uma grande chance para que os conhecimentos necessários para a realização das atividades não sejam percebidos e identificados pelos indivíduos.

Amparados nas considerações de Spender (1996) e Davenport e Prusak (1998), autores como Bartol e Srivastava (2002), Ipe (2003), Tonet e Paz (2006), Yi (2009), Oliveira, Caldeira e Romão (2012), Faoro e Oliveira (2014) e Ramayah, Yeap e Ignatius (2014) ressaltam que o compartilhamento do conhecimento deve estar localizado no centro da discussão que envolve a compreensão da gestão do conhecimento como ação organizacional que proporciona a utilização do conhecimento em prol dos objetivos organizacionais.

A partir do contexto de tais discussões, percebe-se um incremento do debate em torno das nuances ambientais que afetam o conhecimento organizacional, tendo-se como premissa que a organização é um sistema aberto que interage com o ambiente, ao mesmo tempo em que sofre influência deste no desenvolvimento de processos de aprendizagem organizacional (Sirmon, Hitt, \& Ireland, 2007).

Alavi e Leidner (2001), Sabherwal e Becerra-Fernandez (2003), Oliveira et al. (2012), Amayah (2013), Ragab e Arisha (2013) e Faoro e Oliveira (2014) pontuam que as ações de gestão de conhecimento envolvem a identificação, criação, aquisição, compartilhamento e atualização do conhecimento, tornando-o disponível para a organização, no momento em este for necessário e requisitado. As ponderações desses autores ratificam a importância de que o estabelecimento de procedimentos e rotinas administrativas que propiciem o compartilhamento 
e fluxo de conhecimento se constitui em um antecedente essencial para que a organização crie um ambiente propício e facilitador para o compartilhamento do conhecimento.

O debate produzido por tais autores encontra respaldo nas pesquisas de Lipshitz e Popper (1996), Lipshitz, Popper e Friedman (2002), López, Léon e Ordás (2005) e Isidro-Filho (2009) e Pokharel e Choi (2015) nas quais os autores defendem que para que haja o compartilhamento do conhecimento é essencial que sejam fomentadas algumas situações rotineiras de aprendizagem. Essas situações de aprendizagem são denominadas pelos autores como mecanismos de aprendizagem, os quais são definidos como sendo os arranjos e procedimentos institucionalizados utilizados pela organização para coletar, analisar, armazenar, disseminar e utilizar conhecimentos essenciais para seu desempenho e de seus membros (IsidroFilho, 2009).

Ao aproximarem os conceitos de gestão de conhecimento e mecanismos de aprendizagem, Lipshitz e Popper (1996), Lipshitz et al. (2002), López et al. (2005) e IsidroFilho (2009) reafirmam a importância de que o processo de compartilhamento de conhecimento seja fomentado por um conjunto de ações amparadas no suporte proporcionado pela alta administração aos indivíduos.

Debruçados nesse pressuposto, administradores, pesquisadores e consultores têm se perguntado como desenhar mecanismos e ações de gestão de conhecimento que maximizem a produtividade (Wiig \& Jooste, 2003; Pokharel \& Choi, 2015), a agilidade e o trâmite dos ativos intelectuais da organização (Teece, Pisano, \& Shuen, 1998; Wee \& Chua, 2013; Panahi, Watson \& Partridge, 2013), ressaltando a existência de uma discussão atual e relevante para a compreensão de tais ações gerenciais no contexto dos Estudos Organizacionais.

O presente estudo está dividido em seções que aprofundam os aspectos contextualizados nesta introdução. Posteriormente será abordado o referencial teórico que contempla algumas reflexões sobre o conhecimento organizacional, a gestão do conhecimento, o compartilhamento 
do conhecimento e a relação das ações de gestão de conhecimento (mecanismos de aprendizagem) com o compartilhamento do conhecimento. Após isso são apresentados os procedimentos metodológicos que amparam a condução da pesquisa e a análise de dados realizada. Por fim serão abordadas algumas conclusões, limitações e uma proposta de agenda de pesquisa.

Todavia, o desencadeamento das seções citadas acima é precedido pela delimitação do problema de pesquisa, os objetivos a serem atingidos e as justificativas, conforme será tratado a seguir.

\subsection{Problema de Pesquisa}

Conforme contextualizado até aqui, o ambiente organizacional é permeado por questões relacionadas às iniciativas das organizações em influenciar as interações dos indivíduos no ambiente organizacional.

Todavia permanece a lacuna de pesquisa a respeito de teste empírico sobre a hipótese de que os mecanismos de aprendizagem influenciam o compartilhamento do conhecimento, levando-se em consideração a intensidade dessa relação e o fator preditivo dos mecanismos de aprendizagem sobre o compartilhamento do conhecimento.

A partir desta perspectiva, e levando-se em consideração as iniciativas da organização em implantar ações de gestão, emerge a pergunta central desta pesquisa: levando-se em consideração o contexto de organizações da Administração Pública Direta Federal, qual a influência de mecanismos de aprendizagem proporcionados pelas organizações sobre o compartilhamento do conhecimento no ambiente organizacional? 


\subsection{Objetivo Geral}

Em consonância com a pergunta de pesquisa apresentada, o objetivo geral da pesquisa consiste em identificar empiricamente a influência de mecanismos de aprendizagem proporcionados por organizações sobre o compartilhamento do conhecimento no ambiente organizacional.

\subsection{Objetivos Específicos}

Os objetivos específicos que auxiliarão na condução e análise do ambiente a ser investigado são os seguintes:

1. Adaptar uma escala psicométrica para mensurar o construto mecanismos de aprendizagem.

2. Elaborar uma escala psicométrica para mensurar o construto compartilhamento do conhecimento.

3. Mensurar a intensidade da relação de mecanismos de aprendizagem sobre o compartilhamento do conhecimento.

4. Testar o efeito preditivo dos mecanismos de aprendizagem sobre o compartilhamento do conhecimento.

\subsection{Justificativa}

A condução de uma pesquisa no setor público, analisando aspectos do processo de compartilhamento do conhecimento e da influência das condições proporcionada pela própria organização para a sua gestão, tem a sua origem em justificativas acadêmicas, organizacionais e sociais. 
No que diz respeito à justificativa acadêmica, Tsoukas (2009) destaca a importância de que seja aprofundada a análise dos aspectos do contexto organizacional que proporcionam ao indivíduo o afastamento momentâneo de suas crenças, possibilitando a absorção de outros conceitos frutos das interações vividas no ambiente social.

De forma convergente, Gherardi (2009) ressalta a importância de que a investigação sobre a relação existente entre as ações organizacionais e o compartilhamento do conhecimento seja analisada com maior profundidade. Gherardi (2009) enfatiza que muitas vezes essas ações estão imbricadas na organização de forma tácita, acarretando na dificuldade do indivíduo em se aproximar dessas iniciativas organizacionais, sugerindo que sejam criadas condições favoráveis pela organização para a sua proliferação no ambiente de trabalho (Nonaka \& von Krogh, 2009).

Huber (2001), Bose (2004), Alvarenga Neto e Choo (2010) reafirmam a relação existente entre as condições propiciadas pelas organizações para as interações entre os indivíduos e o compartilhamento do conhecimento, destacando a possibilidade de que futuras pesquisas se aprofundem nas possíveis relações entre o compartilhamento do conhecimento e as ações de gestão do conhecimento promovidas pela organização, tais como tecnologias e processos de trabalho, os quais podem proporcionar o estabelecimento de redes de pessoas nas quais o conhecimento é compartilhado.

Desta forma, sob a perspectiva acadêmica, a presente pesquisa se ampara na lacuna existente na exploração da intensidade da relação entre as condições proporcionadas pela organização para o compartilhamento do conhecimento e o compartilhamento do conhecimento constituído nesse mesmo ambiente.

Do ponto de vista organizacional, Malecki (2010) resgata acadêmicos como Foray (2004) para contestar a perspectiva imprecisa que concebe apenas as organizações com um consolidado setor de Pesquisas e Desenvolvimento (P\&D), além de alguns setores industriais, 
como ambientes com potencial para criar e compartilhar novos conhecimentos. Ao sustentar esta crítica, o autor afirma que o conhecimento não é estático, nem tão pouco está concentrado em organizações de quaisquer tipos, pois o conhecimento está espalhado e é onipresente no contexto de todas as organizações. Embasado nessa afirmação, Malecki (2010) destaca a possibilidade de que os estudos sobre o tema sejam direcionados para o âmbito da administração pública.

Ainda no âmbito organizacional, Evans e Alleyne (2009) ressaltam a importância de que seja aprofundada a análise sobre a influência que fatores do contexto organizacional podem exercer sobre a interação dos indivíduos.

Em face do que foi exposto em relação a recomendações de autores para estudos a serem realizados e os objetivos desta dissertação acredita-se que este estudo contribuirá para a análise e a compreensão do impacto que diferentes ações de gestão de conhecimento podem causar no compartilhamento do conhecimento entre os sujeitos, proporcionando subsídios para a melhor tomada de decisão no ambiente organizacional.

Ainda sob o aspecto organizacional, o presente estudo fomentará o repensar da influência que ações de gestão de conhecimento implantadas pela organização podem exercer no intercambio de conhecimento fruto das interações sociais dos indivíduos, nas maneiras formais e informais de contato com o conhecimento e no acesso aos repositórios físicos e virtuais da organização.

Sob a perspectiva social, Batista (2012) e Riege e Lindsay (2006) evidenciam o importante papel fomentador desempenhado pelo governo em relação ao desenvolvimento de ações revestidas de eficiência, transparência e constante coordenação entre os diversos órgãos governamentais. A necessidade de tornar público os resultados obtidos, e toda a dinâmica processual concebida para a realização da atividade pública, implicam às organizações uma responsabilidade social capaz de alterar a maneira como é visto e tratado o processo de 
conhecimento organizacional, conferindo, enfim, o seu devido valor estratégico para a organização e para toda a sociedade (Riege \& Lindsay, 2006).

Por fim, a condução de tal investigação no ambiente público proporciona uma oportunidade singular de analisar as ações tomadas no ambiente de organizações que, por sua constituição precípua, existem para prestar os melhores serviços para a sociedade. Analisar a maneira como o conhecimento é compartilhado e gerido representa um esforço no sentido de desenvolver conhecimento que poderá influenciar positivamente a eficiência dos serviços públicos prestados aos cidadãos (Wiig, 2002). 


\section{REFERENCIAL TEÓRICO}

Nesta seção será abordado o arcabouço teórico que contextualiza a evolução da discussão em torno da importância das ações de gestão do conhecimento e os aspectos que permeiam o compartilhamento do conhecimento organizacional.

Inicialmente será resgatado o diálogo travado por acadêmicos, por meio de produções teóricas e empíricas em torno do conhecimento organizacional, as quais ajudaram na consolidação do debate em torno da variável no âmbito acadêmico.

Após a análise dessas produções, tratar-se-ão, em seções específicas, das ações de gestão de conhecimento, do processo de compartilhamento do conhecimento e da relação entre as ações de gestão do conhecimento e o compartilhamento do conhecimento organizacional, levando-se em consideração a vasta produção científica presenciada na literatura.

\subsection{Conhecimento Organizacional: Evolução de Reflexões}

Em 1959, na obra "The Theory of the Growth of the Firm”, Penrose afirma que a organização deve ser estudada como um dinâmico processo em que se busca a melhor utilização e interação dos recursos disponíveis. O autor argumenta que a organização é um “apanhado de recursos", e que o seu crescimento está diretamente relacionado com a forma como se lida com o desenvolvimento de ideias, experiências e conhecimentos produzidos pelos seus integrantes e colaboradores.

Posteriormente, na obra "The Tacit Dimension", Polanyi (1962), aborda a discussão em torno da geração do conhecimento organizacional, sugerindo que o conhecimento é composto a partir da combinação de ingredientes tácitos e explícitos, sendo que a característica intangível do primeiro o credencia como de difícil identificação e compartilhamento. 
O autor sugere que os sujeitos possuem uma capacidade muito maior de saber realizar atividades do que propriamente explicar a maneira como tais ações são executadas e conduzidas. Esta dialética entre o saber fazer e a articulação e externalização desse conhecimento confere ao aspecto tácito uma dificuldade maior de transmissão, tendo em vista a sua associação às habilidades desenvolvidas e às experiências pessoais dos indivíduos.

Ainda nos anos de 1960, o filósofo e sociólogo Mead (1967) deu contornos psicológicos ao modo de ver o fenômeno da criação do conhecimento. Segundo sua perspectiva, a criação do significado possui estreita relação com os processos sociais, sendo ambos provenientes das interações existentes entre os indivíduos. Sob esta ótica, o conhecimento emerge da comunicação oral e gestual que ocorre em um contexto no qual é proporcionada a ocorrência de tais ações.

Posteriormente, Williamson (1975) enfatiza que a criação do conhecimento é influenciada pelas limitações racionais que envolvem os aspectos neurofisiológicos e de linguagem. Segundo o autor, se por um lado há de se considerar as limitações de cada indivíduo em processar, armazenar e retransmitir as informações, por outro, a linguagem utilizada possui limitações no que diz respeito à capacidade de proporcionar a articulação das sensações dos sujeitos por meio da utilização de números, gráficos e quaisquer outros instrumentos que os façam serem entendidos por outros interlocutores.

As considerações de Polanyi (1962), Mead (1967) e Williamson (1975), ganham novo direcionamento no campo científico da Administração por meio do trabalho de Nelson e Winter (1982). Ao proporem a discussão acerca do modus operandi das organizações, tais autores credenciam as rotinas organizacionais como o material genético da organização, estando calcadas na estrutura burocrática assumida, e implicitamente nos aspectos culturais intrínsecos a cada organização. 
Sob a mesma tônica, autores como Teece (1982) elevam o conhecimento ao status de recurso de extrema importância para as organizações. Ao questionar a abordagem realizada pelas teorias neoclássicas, o autor reivindica para o conhecimento o protagonismo de fator que viabiliza a compreensão das nuances intramuros da firma. De forma convergente, argumentações sobre a teoria da firma baseada em recursos ratificam a posição do conhecimento como ativo que simboliza a vantagem de uma organização frente às demais de seu ambiente (Reed \& DeFillipi, 1990; Barney, 1991).

Porter e Millar (1985) incrementam a análise do fenômeno ao argumentar que as companhias não possuem alternativas senão aprender a tratar as informações e conhecimentos gerados no âmbito organizacional, de forma que o conhecimento produzido seja revertido em diminuição de custos e fomente a diferenciação frente às demais organizações do setor.

Desde então, um grande esforço tem sido demandado com o objetivo de que sejam descortinadas as condições propícias para que as organizações identifiquem as fontes de vantagem competitiva, ao mesmo tempo em que tais fontes possam ser combinadas, implantadas e protegidas (Prahalad \& Hamel, 1990).

As considerações encontradas em tais trabalhos residem na ascensão do conhecimento como recurso de características raras, difícil de ser copiado e extremamente valioso, as quais pregam que a fonte de vantagem competitiva da firma emerge do conhecimento específico e intangível que possui, ou seja, o poder da organização em gerar conhecimento consiste na sua capacidade de articular o conhecimento existente na própria organização (Spender, 1996).

Dentro do contexto dessa discussão, surgem teorias e explicações dos fenômenos que permeiam o conhecimento organizacional.

Nonaka (1994) propõe uma estrutura em que são detalhadas as formas de conversão entre conhecimento tácito e explícito, por meio do processo SECI (Socialização, Externalização, Conversão e Internalização). Posteriormente, Nonaka e Takeuchi (1995) 
inserem este processo de conversão na análise das fases de criação do conhecimento, denominando-as de compartilhamento do conhecimento tácito, criação dos conceitos, justificação dos conceitos, construção de um arquétipo e, por fim, a difusão do conhecimento. Esta última fase caracteriza a transferência do conhecimento do indivíduo para outros níveis da organização, tipificando o aspecto de transição do indivíduo para o nível organizacional, como se o conhecimento fosse criado "organizacionalmente".

Zander e Kogut (1995) acrescentam que a dicotomia existente entre o conhecimento tácito e explícito é baseada na habilidade e nas formas de os conhecimentos serem codificados e transmitidos: quando o conhecimento é possível de ser codificado, a sua transmissão e assimilação são facilitadas. Sendo assim, a padronização de procedimentos facilitaria a transmissão de conhecimentos em sua forma explícita.

Em meio à profusão de publicações que se sucedeu, percebe-se uma tendência cada vez maior no tratamento estratégico do conhecimento (Peteraf, 1993; Oliveira, 1999). Autores como, Ndlela e du Toit (2001), Kim, Yu e Lee (2003) e Tseng (2008), são incisivos ao abordar a importância de que as atividades de aquisição, compartilhamento e retenção de conhecimento sejam planejadas com base em estágios que permitam a melhor concepção e aplicação de ações que permitam gerenciar o conhecimento organizacional.

Os autores destacam ser necessário que a organização se questione quanto ao impacto que tais ações de gestão podem causar no valor do produto ou serviço fruto da sua atividade, quão raro e singular é o modelo de gestão adotado pela organização, em que intensidade o projeto de gestão é difícil de ser imitado por outra organização do meio e, por fim, a necessidade de que sejam disponibilizados sistemas que suportem as práticas do modelo de gestão (Ndlela \& du Toit, 2001; Kim et al., 2003; Tseng, 2008).

Ndlela e du Toit (2001), Kim et al. (2003) e Tseng (2008) defendem o planejamento de uma estratégia de gestão de conhecimento como sendo o processo pelo qual a organização 
promove a análise de suas fraquezas, pontos fortes e oportunidades de gestão de conhecimento que auxiliarão na consecução de seus objetivos. O planejamento da estratégia de gestão de conhecimento destacado pelos autores pode ser dividido em fases, conforme os estágios descritos a seguir.

Primeiro é necessário que a organização analise a sua orientação para a gestão do conhecimento, no que diz respeito a como as lideranças existentes compreendem tal atividade e como aspectos da cultura organizacional coexistem com essa iniciativa. Em um segundo momento é necessário que sejam avaliadas as condições estratégicas externas à organização tais como dificuldades e oportunidades, ou seja, a organização deve perseguir a leitura do ambiente interno e externo na qual esteja inserida (Ndlela \& du Toit, 2001; Kim et al., 2003; Tseng, 2008).

O terceiro passo consiste na formulação de uma estratégia que seja afeita às condições diagnosticadas anteriormente, na qual é primordial que a organização esteja atenta para a exposição clara dos seus objetivos, assim como deve primar para que os indivíduos estejam alocados em funções compatíveis com o seu conhecimento. Em seguida, é necessário que seja desenvolvido um plano que estabeleça as ações que proporcionem a aquisição, criação, compartilhamento e retenção do conhecimento importante para a organização, para que, finalmente, seja implantada e avaliada a estratégia de gestão de conhecimento adotada (Ndlela \& du Toit, 2001; Kim et al., 2003; Tseng, 2008).

Com a intenção de aprofundar a análise em um dos estágios de elaboração do plano de gestão de conhecimento, houve uma série de trabalhos direcionados para a análise das ações de gestão de conhecimento.

Probst, Raub e Romhardt (2002) e Heisig (2009) se unem na defesa de que sejam detalhadas as ações de gestão de conhecimento com base em modelos que contemplem essas 
atividades, proporcionando com que sejam mais bem pensadas as atividades afetas à implantação das ações de gestão do conhecimento organizacional.

Nesta perspectiva, Becerra-Fernadez (2000) discorre sobre algumas definições e importância dos Knowledge Management Systems (Sistemas de Gestão de Conhecimento). O autor argumenta que tais sistemas existem para que o conhecimento importante para a organização seja adquirido, compartilhado, e gerenciado pelos sujeitos e pelos sistemas disponíveis. Ao enfatizar os aspectos da gestão de conhecimento a serem adotados pela organização, o autor sugere que além de o sistema de gestão ser utilizado como um repositório, este pode viabilizar o mapeamento das competências e conhecimentos existentes dentro da organização.

As considerações realizadas por todos esses autores apresentam uma evolução, na qual o conhecimento organizacional ascende da condição de ativo importante da organização à protagonista do ambiente organizacional, sugerindo que sejam pensadas as formas como esse conhecimento transita entre os indivíduos no ambiente organizacional, bem como nas possibilidades de ações que facilitem a tramitação desse mesmo conhecimento, conforme será abordado nas seções a seguir.

\subsection{Gestão do Conhecimento Organizacional}

A seção anterior tratou do debate travado pela comunidade acadêmica em torno das formas de se analisar o conhecimento organizacional. Contudo, tendo em vista a amplidão do tema, esta seção tem o objetivo de detalhar e definir os atributos associados às ações de gestão de conhecimento, destacando a iniciativa de alguns autores em tentar analisar as particularidades e influência dessas ações de gestão dentro do contexto organizacional. 
Sob o contexto dessa discussão, Choo (2003) afirma que gestão do conhecimento se constitui na elaboração da estratégia organizacional, no que diz respeito à estrutura, processos e sistemas, com o objetivo de que se tenha acesso ao conhecimento necessário para a consecução dos objetivos da organização.

Probst et al. (2002) entendem gestão de conhecimento como uma estrutura montada para auxiliar os administradores no tratamento do conhecimento, estimulando ações e práticas que viabilizem o reconhecimento de ativos intelectuais, ao mesmo tempo em que proporciona soluções pontuais para os problemas organizacionais.

Xavier, Oliveira e Teixeira (2012) e Hartung e Oliveira (2013) afirmam que a gestão de conhecimento representa uma forma de as organizações identificarem os conhecimentos necessários para que seja possível aumentar a produtividade e a eficiência em longo prazo. Complementarmente, os autores definem gestão do conhecimento como sendo o processo no qual a organização cria, captura, adquire, compartilha e utiliza o conhecimento que sustente obtenção dos objetivos organizacionais.

A confluência das abordagens propostas por Choo (2003), Probst et al. (2002), Xavier et al. (2012) e Hartung e Oliveira (2013) permite estabelecer as fases da gestão de conhecimento como sendo identificação, criação, compartilhamento, utilização e armazenamento do conhecimento, as quais serão tratadas a seguir.

A identificação diz respeito ao processo em que a organização busca o mapeamento dos principais conhecimentos necessários para a consecução dos seus objetivos, bem como são apontados os "vazios" de conhecimento que precisam ser preenchidos (Batista, 2012). Probst et al. (2002) e Choo (2003) acrescentam que esta fase de identificação deve abranger tanto o ambiente interno quanto o externo da organização.

A criação do conhecimento diz respeito ao processo em que novos conhecimentos são produzidos como fruto da interação entre os sujeitos, transcendendo do nível do indivíduo à 
mais alta esfera organizacional (Nonaka, 1994; Nonaka \& Takeuchi, 1995). Aliado a esta perspectiva, Probst et al. (2002) e Batista (2012) pontuam que a administração deve conjugar todos os esforços para que se desenvolvam as capacidades necessárias à organização.

O compartilhamento do conhecimento diz respeito ao processo em que ocorre o compartilhamento de informações, ideias, sugestões e experiências entre indivíduos (Bartol \& Srivastava, 2002). Szulanski (2000) acrescenta que o compartilhamento do conhecimento pode ser influenciado por fatores específicos, tais como a habilidade em transferir e receber conhecimento da fonte emissora e do receptor, a complexidade do conhecimento a ser transmitido e o contexto em que o fenômeno ocorre, aspectos estes que influenciam diretamente na assimilação do conhecimento compartilhado pelo destinatário ou receptor da mensagem (Tonet \& Paz, 2006).

Probst et al. (2002) e Hartung e Oliveira (2013) acrescentam que o compartilhamento viabiliza que as experiências vividas pelo indivíduo se convertam em conhecimentos disponíveis para outros ambientes da organização.

A utilização diz respeito à fase em que o conhecimento é aplicado em consonância com os objetivos da organização (Xavier et al., 2012; Hartung \& Oliveira, 2013). Ou seja, como consequência das fases de criação e de compartilhamento, espera-se que o conhecimento seja utilizado nos processos, produtos e serviços, a serem realizados pela organização (Batista, 2012).

Por fim, a fase de armazenamento do conhecimento tem o objetivo de preservar o conhecimento no ambiente intramuros da organização (Nonaka, 1994). Probst et al. (2002) ratificam que o conhecimento organizacional não está disponível a qualquer momento, e que a retenção dos conhecimentos necessários para as atividades organizacionais requer ações de gestão (Xavier et al., 2012; Hartung \& Oliveira, 2013). 
De forma convergente a este debate conceitual, Terra (2001) analisa a possível relação existente entre a efetividade da gestão de conhecimento e os resultados atingidos pelas organizações. As considerações colocadas pelo autor apontam para o estágio de implantação de ações de gestão de conhecimento, como será analisado a seguir.

Com a argumentação de que a principal vantagem das organizações reside no conhecimento tácito dos seus indivíduos, Terra (2001) pontua que a gestão de conhecimento implica na adoção de ações gerenciais que conciliem esforços nos planos organizacional/individual e estratégico/operacional, sugerindo que tais atividades de gestão possibilitem o compartilhamento de conhecimento na organização (Amayah, 2013; Ragab \& Arisha, 2013).

Com base em uma revisão bibliográfica, o autor seleciona sete dimensões que devem ser consideradas ao se analisar a adoção de ações de gestão associadas ao conhecimento organizacional: alta administração, cultura organizacional, estrutura organizacional, política de administração de recursos humanos, sistemas de informação, mensuração de resultados e aprendizagem com o ambiente.

Especificamente em relação à alta administração, Terra (2001) afirma que a organização deve delinear ações que estejam em convergência com as estratégias, metas e objetivos da organização, de modo que os esforços empregados pelos indivíduos estejam direcionados para os campos de conhecimento de interesse organizacionais.

Em relação às demais dimensões, Terra (2001) pontua que deve ser cultivada uma cultura organizacional favorável à criação de um ambiente propício à inovação, experimentação, aprendizagem e tolerância ao erro. No que diz respeito à estrutura organizacional, o autor afirma a importância de que sejam admitidos desenhos organizacionais menos hierárquico-burocratizados e mais afeitos às constantes mudanças e desafios. 
A política de recursos humanos é abordada com a percepção da necessidade de aquisição de conhecimento, bem como a difusão e o armazenamento do conhecimento em organizações. O autor aborda tais políticas com ênfase no desenvolvimento de ações que atraiam e mantenha as pessoas na organização, no estímulo de comportamentos que favoreçam os processos individuais e coletivos de criação e compartilhamento de conhecimento, além de tratar a possibilidade de recompensas remuneratórias associadas à aquisição de competências individuais.

Em relação aos sistemas de informação, o autor enfatiza a necessidade de que sejam analisadas as tecnologias disponíveis que possam impulsionar o processo de compartilhamento do conhecimento, ainda que ressalte a importância do contato pessoal, da manutenção de um ambiente de confiança, transparência e colaboração, com vistas à eficiência do processo como um todo.

No que diz respeito à mensuração de resultados, Terra (2001) ratifica a importância de que todo o processo de gestão de conhecimento seja analisado em função da comunicação estabelecida em toda a organização. Finalmente, o aprendizado com o ambiente diz respeito ao relacionamento estabelecido com outras organizações, representadas na figura de clientes, fornecedores, órgãos públicos e quaisquer outros.

Complementarmente ao trabalho de Terra (2001), Heizig (2009) externa a existência de quatro dimensões que são relevantes para o processo de implantação da gestão de conhecimento, sendo as seguintes: dimensão humana, na qual são abordados aspectos culturais, de liderança e de relacionamento entre as próprias pessoas; dimensão organizacional, onde emergem aspectos estruturais e processuais da organização; dimensão tecnológica, na qual são tratados os meios tecnológicos disponíveis para a implantação da gestão; e a dimensão dos processos, na qual são abordados os aspectos de estratégias e controle utilizados pela organização. 
Em outra corrente de pesquisas, autores como Lipshitz e Popper (1996), Lipshitz et al. (2002), López et al. (2005), Isidro-Filho (2009) e Pokharel e Choi (2015) propõem a conciliação entre as ações de gestão de conhecimento e os mecanismos de aprendizagem.

Lipshitz et al. (2002) pontua que o ato de aprender na organização requer a existência dos mecanismos de aprendizagem, os quais são considerados como a "faceta estrutural" da organização, na qual são constituídos os subsistemas em que os indivíduos interagem entre si com o propósito de compartilhar conhecimento e experiências e, consequentemente, aprender no ambiente de trabalho (Lipshitz \& Popper, 1996; Lipshitz et al., 2002).

Tais autores acrescentam que os mecanismos de aprendizagem podem se apresentar de forma integrada, na qual o indivíduo que processa a informação é o mesmo que aplica esse novo conhecimento, ou ainda de maneira não integrada, na qual a compreensão do conhecimento ocorre em indivíduos diferentes daqueles que realizaram as ações. Sob essa perspectiva os mecanismos de aprendizagem apresentam o dualismo, no qual o processo de aprendizagem ocorre de maneira conjunta com a execução da tarefa, ou sob outro prisma, o processo de aprendizagem pode ocorrer em locais diferentes do qual a tarefa foi realizada, tendo em vista o processo de reflexão do indivíduo ou de outros sujeitos que tenham acompanhado o desenrolar das ações (Lipshitz \& Popper, 1996; Lipshitz et al., 2002).

Sob o contexto dessa discussão López et al. (2005) e Isidro-Filho (2009) aproximam o conceito de mecanismos de aprendizagem ao de gestão de conhecimento, ressaltando que ambas as ações são caracterizadas pelo estabelecimento de arranjos e procedimentos institucionalizados, os quais permitem coletar, analisar, armazenar e utilizar conhecimentos e informações para o desempenho das atividades organizacionais. Ou seja, a abordagem realizada por Lipshitz e Popper (1996), Lipshitz et al. (2002), López et al. (2005), Isidro-Filho (2009) e Pokharel e Choi (2015) conclui que as ações de gestão de conhecimento podem ser entendidas 
como os mecanismos de aprendizagem, tendo em vista que ambas têm o objetivo de proporcionar a gestão do ativo "conhecimento" dentro do ambiente organizacional.

O debate apresentado nesta seção em torno das ações de gestão de conhecimento, além da sua conciliação e convergência com os mecanismos de aprendizagem, proporciona que sejam consolidados os principais conceitos tratados, conforme a Tabela 1.

Tabela 1

\section{Revisão Conceitual}

\begin{tabular}{cl}
\hline & É a estrutura montada para auxiliar os administradores no tratamento de ativos \\
& intelectuais, estimulando ações e comportamentos que viabilizem o \\
& reconhecimento do conhecimento necessário à organização, proporcionando \\
Gestão de & que este conhecimento seja adquirido, criado, compartilhado e utilizado para a \\
Conhecimento & consecução dos objetivos da organização (Lipshitz \& Popper, 1996; Lipshitz et \\
& al., 2002; Probst et al., 2002; Choo, 2003; Isidro-Filho, 2009; Xavier et al., \\
& 2012; Hartung \& Oliveira, 2013).
\end{tabular}
2012; Hartung \& Oliveira, 2013).

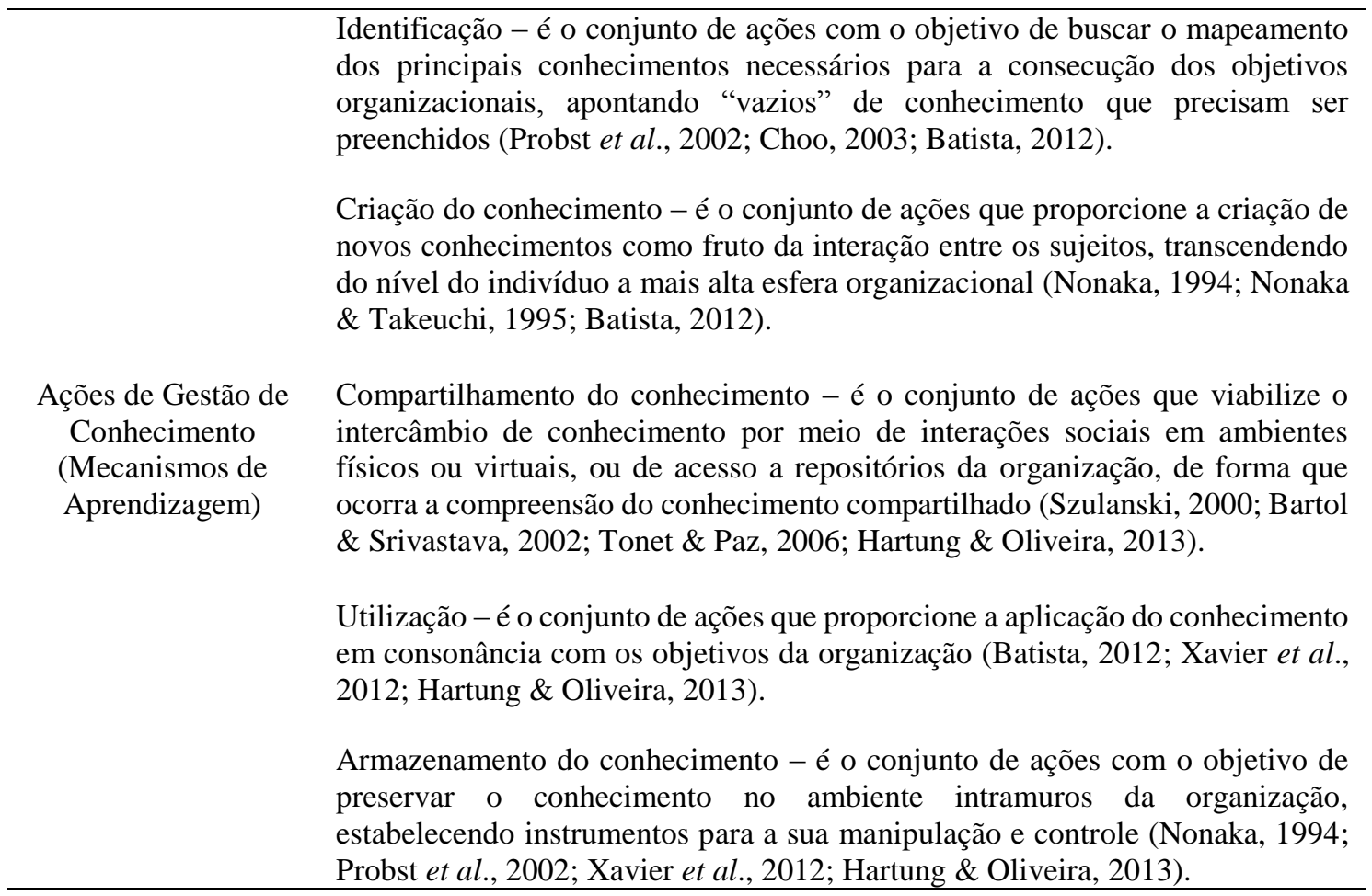

Nota. Fonte: Elaborado pelo autor.

Após a contextualização da conciliação entre as definições de mecanismos de aprendizagem e gestão de conhecimento, as seções futuras abordarão de forma mais específica as particularidades do compartilhamento do conhecimento no ambiente organizacional. 


\subsection{Compartilhamento do conhecimento organizacional}

Ainda que o tema compartilhamento do conhecimento tenha sido abordado na seção anterior, pretende-se aprofundar os debates sobre esse construto, além de detalhar algumas de suas relações com outras variáveis do ambiente organizacional.

Vale destacar que a composição do referencial teórico deste tópico atendeu a alguns critérios para delimitação dos artigos a serem utilizados, os quais serão abordados seguir.

Inicialmente foram analisados os periódicos nacionais da área de Administração, Ciências Contábeis e Turismo, em um lapso temporal de cinco anos, compreendendo o período de 2010 a 2014, que estivessem classificados de A1 a B2, de acordo com a avaliação do Sistema WebQualis, ano-base 2011, do sítio eletrônico da CAPES.

Após isso, levando-se em consideração os periódicos que estivessem ligados pontualmente à área de Administração, foi realizada uma pesquisa de modo a identificar as linhas editorias que pudessem abordar a temática afeta ao compartilhamento do conhecimento organizacional. Como produto desta análise, inicialmente o escopo da investigação foi condensado na pesquisa em 45 periódicos, conforme a Tabela 2.

Tabela 2

Periódicos de Administração utilizados na pesquisa.

\begin{tabular}{ccc}
\hline ISSN & Periódico & Qualis \\
\hline $1807-7692$ & BAR. Brazilian Administration Review & A2 \\
$1808-2386$ & BBR. Brazilian Business Review (English Edition. Online) & A2 \\
$0104-530 X$ & Gestão \& Produção (UFSCAR. Impresso) & A2 \\
$1984-9230$ & Organizações \& Sociedade (Online) & A2 \\
$1982-7849$ & RAC. Revista de Administração Contemporânea (Online) & A2 \\
$2178-938 X$ & RAE - Revista de Administração de Empresas & A2 \\
$1984-6142$ & Revista de Administração (São Paulo. Online) & A2 \\
$0034-7612$ & Revista de Administração Pública (Impresso) & A2 \\
$1679-3951$ & Cadernos EBAPE.BR (FGV) & B1 \\
$1678-4855$ & Desenvolvimento em questão (Unijuí) & B1 \\
$0873-7444$ & Economia Global e Gestão & B1 \\
$1984-6975$ & Faces: Revista de Administração (Belo Horizonte. Online) & B1 \\
$2176-5308$ & Gestão \& Regionalidade (Online) & B1 \\
$1517-3879$ & Organizações Rurais e Agroindustriais (UFLA) & B1
\end{tabular}


1809-2039

1678-6971

1413-2311

1983-0807

1809-239X

$1679-5350$

2175-8077

1982-6486

1807-1775

1677-2067

0103-9989

1980-6302

1984-8196

1984-3925

1678-2089

2177-6652

1980-0193

$1679-5830$

1984-6983

$1678-6483$

1983-8484

1677-7387

2177-8736

2177-5184

1983-716X

$1677-2504$

1983-4659

2176-0756

1676-1901

1983-6635

1980-5160
RAI: Revista de Administração e Inovação

RAM. Revista de Administração Mackenzie (Online)

REAd. Revista Eletrônica de Administração (Porto Alegre. Online)

Revista Brasileira de Gestão de Negócios (Online)

Revista Brasileira de Gestão e Desenvolvimento Regional

Revista de Administração da Unimep

Revista de Ciências da Administração

Revista de Contabilidade e Organizações

Revista de Gestão da Tecnologia e Sistemas de Informação (Online)

Revista Portuguesa e Brasileira de Gestão (Rio de Janeiro)

Revista USP

Análise (PUCRS. Online)

Base (São Leopoldo. Online)

Contabilidade, Gestão e Governança

Contextus (Fortaleza)

Gestão \& Tecnologia

Perspectivas Contemporâneas

Pesquisa \& Desenvolvimento Engenharia de Produção

Pretexto (Belo Horizonte. Online)

RACE: Revista de Administração, Contabilidade e Economia

REBRAE. Revista Brasileira de Estratégia (Impresso)

RECADM: Revista Eletrônica de Ciência Administrativa

REGE. Revista de Gestão

REMark. Revista Brasileira de Marketing

Revista Alcance (Online)

Revista Brasileira de Inovação

Revista de Administração da UFSM

Revista Iberoamericana de Estratégia

Revista Produção Online

RGO. Revista Gestão Organizacional (Online)

S \& G. Sistemas \& Gestão

Nota. Fonte: CAPES (2011) - Área Administração, Ciências Contábeis e Turismo.

Ainda em relação à amostra de periódicos, ressalta-se que, por ser o campo da Administração multidisciplinar, optou-se por realizar uma busca adicional por artigos na base da CAPES, SciELO (Scientific Eletronic Library Online) e Spell (Scientific Periodical Eletronic Library), com o objetivo de maximizar a busca por periódicos que contemplassem o tema da pesquisa. Como consequência dessa nova busca, foram selecionados mais seis periódicos afetos ao objeto dessa investigação, sendo os mesmos listados na Tabela 3.

Tabela 3

Demais periódicos utilizados na pesquisa

\begin{tabular}{ccc}
\hline ISSN & Periódico & Qualis da Área Original \\
\hline $1809-4783$ & Informação \& Sociedade: Estudos & A1
\end{tabular}


1413-9936

0103-3786

$1518-8353$

$1807-8893$

2236-417X

0103-6513
Perspectiva da Ciência da Informação

Transinformação

Ciência da Informação

Em Questão

Perspectiva em Gestão \& Conhecimento

Produção
A1

A1

A2

B1

B1

B2

Nota. Fonte: CAPES (2011).

Após a identificação dos 52 periódicos que seriam utilizados, procedeu-se à pesquisa no sítio eletrônico de cada um deles, utilizando-se a palavra-chave "compartilhamento do conhecimento", "knowledge sharing", "transferência do conhecimento" e "knowledge transfer".

Em relação aos periódicos internacionais, optou-se por realizar uma busca nas bases de dados Emerald, ProQuest, SAGE, Web of Knowledge, abrangendo o período de 2010 a 2014, utilizando as mesmas palavras-chaves "knowledge sharing" e "knowledge transfer". Posteriormente, tanto na amostra de artigos nacionais, quanto na de artigos internacionais, com o objetivo de ratificar a busca iniciada, foram analisados, um a um, os títulos, os resumos/abstracts e as palavras-chaves dos artigos.

Desta forma, foram selecionados 59 artigos nacionais e 139 artigos internacionais, os quais compuseram a amostra de artigos analisados, tendo em vista a ancoragem nos seguintes critérios: os artigos deveriam abordar o tema compartilhamento do conhecimento no título, no resumo ou nas palavras-chaves; o artigo deveria ter sido produzido no período de 2010 a 2014; e, principalmente, os artigos deveriam abordar o fenômeno compartilhamento do conhecimento do conhecimento como sendo o "intercâmbio de conhecimento por meio de interações sociais em ambientes físicos ou virtuais, ou de acesso a repositórios da organização, de forma que ocorra a compreensão do conhecimento compartilhado" (Nonaka \& Takeuchi; 1995; Nonaka e Konno, 1998; Nonaka et al., 2000; Szulanski, 2000; Bartol \& Srivastava, 2002; Probst et al., 2002; Tonet \& Paz, 2006; Hartung \& Oliveira, 2013). 
Styhre, Ollila, Roth, Williamson e Berg (2008) pontuam que a pesquisa do compartilhamento do conhecimento emergiu como um campo de destaque na gestão do conhecimento (Brown \& Duguid, 2001). Ao abordarem a complexidade das pesquisas a respeito de compartilhamento do conhecimento, Styhre et al. (2008) destacam três correntes bem definidas na literatura: a primeira diz respeito aos estudos que se concentram em analisar os setores da organização que se envolvem no compartilhamento do conhecimento, tais como comunidades de práticas (Wenger, McDermott \& Snyder, 2002) e equipes de projetos (Scarbrough, Swan, Laurent, Bresnen, Edelman \& Newell, 2004; Boh, 2007); uma segunda via enfatiza a identificação de mecanismos para o compartilhamento do conhecimento (Lipshitz \& Popper, 1996; Lipshitz, et al., 2002), os quais podem englobar tecnologias de informação (Hayes \& Walsham, 2001) e contextos capacitantes específicos (Nonaka, Toyama, \& Konno, 2000); por último existe uma corrente que se concentra na análise do conhecimento subjacente às práticas dos indivíduos (Gherardi, 2009), além da característica de "viscosidade” do próprio conhecimento (Szulanski, 2000).

A composição deste referencial teórico se ampara na perspectiva cognitiva, a qual suporta a influência dos mecanismos de aprendizagem (ações de gestão de conhecimento) no compartilhamento do conhecimento, tendo em vista o conhecimento ser visto como ativo que pode transcender a seções e departamentos organizacionais (Antonello \& Godoy, 2011).

Shrivastava (1983) pontua que as análises do processamento de informações e conhecimentos na organização são provenientes da psicologia cognitiva, datadas da década de 1950. Antonello e Godoy (2011) afirmam que a perspectiva cognitiva considera o conhecimento como sendo um ativo acumulado pelos indivíduos de forma consciente, ou seja, o processo de aprendizagem se constitui do desenvolvimento de novos conhecimentos, os quais influenciam no comportamento dos indivíduos (Chiva \& Alegre, 2005; Assudani, 2009). 
Para além da simples utilização de experiências anteriores pelos sujeitos, a perspectiva cognitiva enfatiza que os indivíduos no ambiente organizacional interpretam e compreendem a realidade de acordo com as particularidades do seu sistema cognitivo (Antonello \& Godoy, 2011), podendo este processo ser fomentado pela utilização de mecanismos de aprendizagem, que se constituem nas ações de gestão de conhecimentos, as quais são essenciais para o desempenho individual e organizacional.

Contrapondo-se a esta perspectiva técnica e cognitiva, Gherardi e Nicolini (2000) enfatizam que a produção e a reprodução de conhecimento é algo que surge da interação dos indivíduos em sociedade, ou seja, a aprendizagem está intrinsicamente associada às práticas presentes no cotidiano dos indivíduos. As autoras concluem que o "saber" não está dissociado do "fazer", e que qualquer oportunidade na organização é uma ocasião para aprendizagem, sejam estas estabelecidas por meios formais ou informais (Gherardi, 2009).

Sob o contexto dessa discussão, "The Concept of “Ba”: Building a Foundation for Knowledge Creation" (Nonaka \& Konno, 1998) fomenta argumentações sobre a importância do contexto organizacional e dos fatores sociais que afetam o processo de criação e de compartilhamento do conhecimento.

Nonaka e Konno (1998) e Nonaka et al. (2000) reafirmam a necessidade de que a criação e o compartilhamento do conhecimento sejam contextualizados no complexo ambiente organizacional. Os autores ressaltam que a organização não é uma máquina onde o conhecimento é processado. Ao invés disso, a organização se constitui em um conjunto de ambientes propícios para a interação entre os indivíduos, podendo estes ambientes serem físicos (escritórios, reuniões de negócios) ou virtuais (e-mail, rede intranet e teleconferência). Além disso, os autores ressaltam a existência de ativos do conhecimento, tais como as lideranças existentes no ambiente, as quais podem influenciar na ocorrência do fenômeno. 
De forma convergente a esta perspectiva, Bartol e Srivastava (2002) resgatam Nahapiet e Ghoshal (1998) para afirmar que o conhecimento organizacional é fruto das trocas dos conhecimentos e experiências dos indivíduos no ambiente de trabalho. Ao definirem compartilhamento do conhecimento como sendo o compartilhamento de informações, ideias, sugestões e experiências entre indivíduos, os autores afirmam que o conhecimento compartilhado pode ser explícito ou tácito, sendo que o primeiro pode ser transferido por meio de conversas e documentos, enquanto o segundo é veiculado por meio de socialização, observação e outras situações de aprendizagem formal ou informal (Nonaka, 1994).

Por outro lado, Hendriks (1999) afirma que o conhecimento não é algo comum e material, a ponto de ser facilmente compartilhado, sendo, ao contrário, algo extremamente ligado ao saber subjetivo dos sujeitos da organização. Hendriks (1999) pondera que o processo de compartilhamento de conhecimento requer um ato de reconstrução pelo receptor do conhecimento.

Complementando a ideia anterior, Hendriks (1999) considera o fenômeno do compartilhamento baseado no processo de comunicação que é estabelecido entre o emissor e o receptor, levando-se em consideração que tal processo ocorre de forma consciente ou inconsciente, podendo contar ou não com a boa vontade do emissor. Em contrapartida, o receptor deve ser capaz de perceber as expressões de conhecimentos contidos nos atos, nos discursos, nos simples manuscritos, ou ainda nos documentos formais emanados pelo emissor.

De forma convergente, Szulanski (2000) utiliza o termo transferência do conhecimento para descrever o fenômeno do compartilhamento do conhecimento, destacando que essa transferência não deve ser vista como um ato simplista, no qual existe uma simples troca de conhecimento entre indivíduos, mas sim como um processo composto por diferentes estágios, os quais podem ser influenciados por fatores específicos, tais como a habilidade em transferir 
e receber conhecimento apresentada pela fonte e pelo receptor da mensagem, a complexidade do conhecimento a ser transmitido e o contexto em que este fenômeno ocorre.

Szulanski (2000) se une a von Hippel (1994) e Szulanski (1996) para conceituar compartilhamento do conhecimento como sendo o processo no qual as organizações mantem as rotinas existentes, além de possibilitar que estes ativos organizacionais sejam recriados e reagrupados em novos grupos de rotinas organizacionais.

Szulanski (2000) ratifica a complexidade envolvendo o processo de compartilhamento do conhecimento ao afirmar que o sucesso desse processo depende do funcionamento da engrenagem composta por alguns preditores, entre os quais estão a fonte do conhecimento, o canal de transmissão utilizado, a mensagem veiculada, o receptor da mensagem e o contexto em que o próprio fenômeno ocorre.

Szulanski (2000) destaca que a complexidade do fenômeno consiste na dificuldade de se criar um ambiente harmonioso, no qual todos esses preditores fluam de forma eficiente. Esta dificuldade em se atingir a fluidez no processo de compartilhamento do conhecimento caracteriza o que Szulanski (2000) denomina de stickness (viscosidade, em português), como uma característica típica do fenômeno.

Ipe (2003) sugere que o compartilhamento de conhecimento é basicamente o ato de tornar o conhecimento de um indivíduo disponível para os outros dentro da organização. O autor acrescenta que o compartilhamento se constitui no processo em que o conhecimento de um indivíduo é convertido em uma forma de conhecimento que pode ser compreendida, absorvida e utilizada por outros.

Para Ipe (2003) o compartilhamento do conhecimento não implica na renúncia do conhecimento pelo emissor, mas sim em uma parceria que se estabelece no processo de compartilhamento entre quem compartilha e quem adquire o conhecimento. 
Ainda que não se afastem muito de outras definições, Tonet e Paz (2006) incrementam a discussão ao afirmarem que compartilhamento do conhecimento é uma via de mão dupla: o comportamento do indivíduo de repassar o que sabe às pessoas com quem trabalha proporciona com que receba o conhecimento que elas possuem, de forma que o destinatário ou receptor assimile o conhecimento compartilhado pela fonte ou emissor.

O modelo proposto por Tonet e Paz (2006) concebe o compartilhamento do conhecimento como um processo que pode ser integrado em quatro fases interdependentes, quais sejam iniciação, implementação, apoio e incorporação.

A iniciação diz respeito ao momento em que são tomadas ações para a análise do conhecimento necessário à organização, a identificação das possibilidades de utilização desses conhecimentos, e a busca por fontes de aquisição no ambiente interno e externo. A fase de implementação tem o objetivo de proporcionar a comunicação entre as fontes de conhecimento e os seus potenciais destinatários.

O apoio se refere às ações para a promoção de situações nas quais os novos conhecimentos adquiridos sejam praticados, de forma que seja proporcionada a assimilação pelo aprendiz, ao ponto em que este adquira novas habilidades. Por fim, a incorporação é o momento em que o conhecimento compartilhado transita entre os que deverão utilizá-lo.

Ainda nessa perspectiva de análise, Cardoso e Gomes (2011) afirmam que o compartilhamento do conhecimento pode ocorrer de maneira intencional ou não intencional. A forma intencional ocorre quando a ação se dá de forma consciente, por meio de atitudes explícitas e arquitetadas, tais como reuniões de trabalho, ações de treinamento ou rotatividade intencional dos indivíduos proporcionada pela organização. A forma não intencional ocorre nas conversas das pausas do trabalho e por meio de histórias contadas sobre a realização de tarefas passadas. Cardoso e Gomes (2011) se unem a Polanyi (1962) para afirmar que, enquanto a forma intencional proporciona o compartilhamento do conhecimento em sua forma é 
essencialmente explícita, a maneira não intencional viabiliza com que seja compartilhado o conhecimento em sua forma tácita.

A partir deste ponto da discussão, percebe-se uma grande quantidade de pesquisas que abordam os antecedentes e consequentes do compartilhamento do conhecimento, sendo que os primeiros ora são representados como barreiras, ora são associados como facilitadores.

Dentro deste escopo de pesquisas, van Wijk, Jansen e Lyles (2008) examinam como o compartilhamento do conhecimento dentro da organização pode ser influenciado por antecedentes, tais como as características do conhecimento, aspectos organizacionais e as características da rede de relacionamento estabelecida entre os indivíduos, conforme Tabela 4.

Tabela 4

Síntese dos antecedentes do compartilhamento do conhecimento

\begin{tabular}{|c|c|}
\hline Preditor & Características do Preditor \\
\hline Conhecimento & $\begin{array}{l}\text { - Ambiguidade do conhecimento - é a irredutibilidade do aspecto incerto do conhecimento } \\
\text { em sua forma tácita. }\end{array}$ \\
\hline Organização & $\begin{array}{l}\text { - Idade } \\
\text { - Tamanho } \\
\text { - Descentralização - diz respeito à hierarquia e a intensidade que o processo decisório é } \\
\text { disperso na organização. } \\
\text { - Capacidade de absorção - é a habilidade em reconhecer assimilar e aplicar o novo } \\
\text { conhecimento externo adquirido (Lane, Koka, \& Pathak, 2006; Zahra \& George, 2002). }\end{array}$ \\
\hline \multirow{3}{*}{$\begin{array}{l}\text { Relações de } \\
\text { trabalho }\end{array}$} & 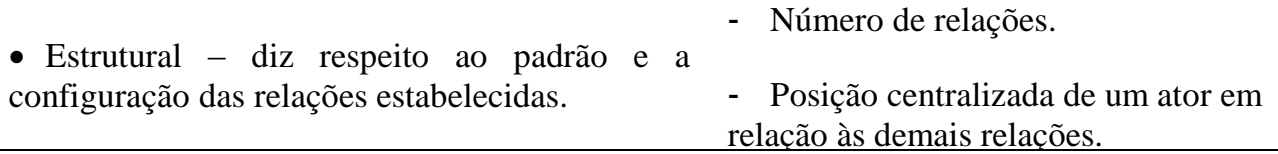 \\
\hline & $\begin{array}{ll}\text { - Relacional - é o aspecto associado à natureza } & - \text { Proximidade das relações. } \\
\text { das relações constituídas. } & - \text { Confiança. }\end{array}$ \\
\hline & $\begin{array}{lll}\text { - Cognitiva - relaciona-se aos recursos que } & - \text { Visão compartilhada e sistemas } \\
\text { proporcionam as representações compartilhadas } & \text { comuns. } \\
\text { e as interpretações de significado. } & - \text { Distância cultural. }\end{array}$ \\
\hline
\end{tabular}

Nota. Fonte: Adaptado de van Wijk, Jansen e Lyles (2008).

van Wijk et al. (2008) compõem uma base de dados de 75 artigos científicos, oriundos de periódicos especializados no tema. Amparados em Hunter e Schmidt (2004), os quais afirmam que a meta-análise é apropriada para situações como esta, pois proporciona vantagens no ajustamento dos efeitos de tamanho observados para mensuração estatística, van Wijk et al. (2008) realizam uma meta-análise na amostra de artigos selecionada, estimando os valores médios e a amplitude dos efeitos para as relações entre múltiplas variáveis. 
van Wijk et al. (2008) calculam as correlações médias ponderadas $\left(r_{c}\right)$, em função da amostra corrigida para insegurança (unreliability, em inglês), como um estimador do efeito do tamanho da população $(\rho)$. van Wijk et al. (2008) obtém um $r_{c}$ significativamente negativo ( $r_{c}=-$ $0.22, \mathrm{p}<0.001$ ) para a relação entre ambiguidade e compartilhamento de conhecimento. O efeito do tamanho foi considerado médio (Cohen, 1988), sugerindo que quanto mais tácito e específico é o conhecimento, mais difícil é o seu processo de compartilhamento.

Dentre os resultados achados por van Wijk et al. (2008), a análise realizada suportou a ideia de que existe uma relação positiva entre a capacidade de absorção do conhecimento e o compartilhamento do conhecimento $\left(r_{c}=0.19, \mathrm{p}<0.001\right)$. Por outro lado, os resultados não mostraram evidencias de que a idade da organização e a descentralização do processo decisório tenham relação significativa com o compartilhamento do conhecimento. Ou seja, a hipótese de que organizações jovens e com estrutura descentralizada estão associadas a altos níveis de compartilhamento de conhecimento não foi suportada.

Em relação aos aspectos de relação de trabalho, van Wijk et al. (2008) encontram correlações significativas para a maioria dos preditores definidos. Os autores afirmam existir uma correlação significativa entre o compartilhamento do conhecimento e a proximidade da relação entre os indivíduos $\left(r_{c}=0.29, \mathrm{p}<0.001\right)$, a própria confiança nas relações estabelecidas $\left(r_{c}=0.41, \mathrm{p}<0.001\right)$ e os aspectos cognitivos, no que diz respeito à visão compartilhada e sistemas comuns $\left(r_{c}=0.21, \mathrm{p}<0.01\right)$ e a distância cultural $\left(r_{c}=-0.11, \mathrm{p}<0.05\right)$.

Os resultados encontrados por van Wijk et al. (2008) resgatam as discussões anteriormente levantadas por Szulanski (2000), Ipe (2003) e Tonet e Paz (2006), nas quais os aspectos do compartilhamento do conhecimento são associados a uma relação de dependência com a capacidade comunicação, interpretação e absorção das partes envolvidas no processo (Kogut \& Zander, 1992). 
De forma geral, ambas as pesquisas abordam discussões sobre a importância do aprofundamento da análise dos antecedentes e preditores do compartilhamento do conhecimento organizacional, ressaltando o paradoxo abordado por Coff, Coff, e Eastvold (2006): ao mesmo tempo em que se eleva o conhecimento a uma categoria de ativo essencial para a organização e de difícil imitação pelos competidores, mais esse conhecimento se torna difícil de ser interpretado, assimilado e compartilhado dentro dos muros da organização.

Por outro lado, Tsoukas (2003), Gourlay e Nurse (2005), Gourlay (2006), Ribeiro e Collins (2007) e Souto (2013), integram um grupo de pesquisadores que se contrapõem a qualquer tipo de abordagem teórica generalista e direta que simplifique demasiadamente o processo de compartilhamento do conhecimento. Este grupo de autores consolida o caminho para que a análise do processo de compartilhamento do conhecimento considere a possibilidade de que formas diferentes de conhecimento possam ser criadas por diferentes tipos de comportamentos e influências de fatores organizacionais, sugerindo que o processo como um todo seja analisado em função do conhecimento gerado por meio da interação entre indivíduos e as práticas constituídas dentro da organização. Sob a argumentação de tais autores é sugerida que as perguntas em torno do compartilhamento do conhecimento passem a focar o "como" e o "porquê" do fenômeno, ao invés de apenas o fenômeno em si.

Estas reflexões são materializadas em ponderações de pesquisadores como Sun (2010) que enfatiza a necessidade de que sejam aprofundadas as questões que envolvem a exata natureza e intensidade da influência das ações organizacionais no compartilhamento do conhecimento organizacional.

Em outra frente de pesquisa, ainda que Wiig (2002) já houvesse proposto a diferença na contextualização da gestão do conhecimento entre organizações públicas e privadas, Amayah (2013) é enfática em afirmar que a maioria das pesquisas ainda ocorre no setor privado da economia. Com a consistente argumentação de que o conhecimento é um bem tão valioso para 
as organizações públicas como é para as organizações privadas (Siong, Salleh, Syed Noh Syed, \& Syed-Ikhsan, 2011), Amayah (2013) realiza uma regressão múltipla para identificar a capacidade de predição dos fatores motivação (benefícios pessoais, relacionamento com comunidade e considerações normativas), facilitadores (recompensas, suporte organizacional, confiança, interação social e reciprocidade) e barreiras (nível de encorajamento, nível de empatia, centralização e formalização), em relação ao compartilhamento do conhecimento, conseguido explicar $58,00 \%$ da variância do fenômeno em uma determinada organização pública.

Todos os aspectos relacionados à motivação, quais sejam relacionamento com a comunidade $(\beta=0,328 ; p<0.001)$, considerações normativas $(\beta=0,967 ; p<0.001)$ e benefícios pessoais $(\beta=-0,312 ; p<0.01)$, demonstraram contribuir de forma significativa para a variância no compartilhamento do conhecimento $\left(R^{2}=0,425\right)$. Os três fatores motivacionais explicaram 42,5\% da variância do compartilhamento do conhecimento, sendo que o melhor preditor desse grupo foi o relacionamento com a comunidade, tendo explicado sozinho 39,00\% da variância do compartilhamento do conhecimento. Amayah (2013) destaca que o sinal negativo de benefícios pessoais sugere que a boa vontade em compartilhar conhecimento diminui na medida em que o benefício pessoal aumenta.

Em relação a esta relação inversa entre benefícios pessoais e compartilhamento de conhecimento, Amayah (2013) aponta que tais resultados contrariam algumas pesquisas na área (Chiu, Hsu, \& Wang, 2006; Ardichvili, 2008) e que tal contradição pode estar associada ao fato de que, por vezes, o custo do compartilhamento do conhecimento pode sobrepor os benefícios pessoais. Ou seja, alguns indivíduos ainda se ressentem em compartilhar o conhecimento, uma vez que esta atitude poderia causar a "perda" do seu único valor para a organização (Bock, Zmud, Kim, \& Lee, 2005). 
No que diz respeito aos facilitadores, três aspectos apresentaram um efeito significativo no compartilhamento do conhecimento: interação social $(\beta=0,585 ; \mathrm{p}<0.001)$, recompensas $(\beta=-$ $0,090 ; \mathrm{p}<0.05)$ e suporte organizacional $(\beta=-0,563 ; \mathrm{p}<0.01)$. Os três facilitadores explicaram $1,3 \%$ da variância do compartilhamento do conhecimento.

Os aspectos de reciprocidade e confiança foram excluídos, tendo em vista não apresentar efeito significativo no modelo. Amayah (2013) ressalta que este fato converge para as ponderações de Huang, Davison, \& Gu (2008), nas quais os autores ponderam que uma relação de reciprocidade entre os sujeitos não garante o compartilhamento do conhecimento, pois o conhecimento pode ser compartilhado para tornar o trabalho mais efetivo, e não por que os indivíduos esperam algo em troca.

De forma convergente à Bock e Kim (2002), Amayah (2013) identifica uma relação negativa entre o compartilhamento do conhecimento e o suporte organizacional, sugerindo que tal relação possa estar associada a outras variáveis organizacionais, tais como comprometimento e afeto. No que diz respeito às recompensas, Amayah (2013) sugere que as recompensas podem enfraquecer a relação entre os que ganham e os que não ganham a recompensa.

Os aspectos de barreira de conhecimento explicaram $7,00 \%$ da variância do compartilhamento do conhecimento. Nível de encorajamento $(\beta=0,337 ; \mathrm{p}<0.05)$ e nível de empatia $(\beta=0,345 ; p<0.001)$, contribuíram de forma significativa como preditores para explicar a variância do compartilhamento do conhecimento. No que diz respeito à formalização e à descentralização, os resultados encontrados não apontam quaisquer efeitos significativos destes com o compartilhamento do conhecimento. Todavia, Amayha (2013) ressalta a importância de que esse achado seja contextualizado para a amostra pesquisada, podendo diferir em pesquisas futuras em outras organizações. 
Por fim, Amayah (2013) testa o efeito moderador do suporte organizacional sobre os benefícios pessoais no compartilhamento do conhecimento. O coeficiente do beta achado nessa moderação $(\beta=0.839)$ indica que o aumento do suporte organizacional aumenta o efeito dos benefícios pessoais sobre o compartilhamento do conhecimento.

A pesquisa realizada por Amayah (2013) resgata a importância das condições proporcionadas pela organização para o compartilhamento do conhecimento, destacando a influência de alguns fatores como bons preditores para o compartilhamento do conhecimento. No entanto, os resultados encontrados por Amayha reforçam autores como Lipshitz e Popper (1996) e Lipshitz et al. (2002) ao destacarem que as ações da organização são importantes para a ocorrência do fenômeno, mas existem diversas outras variáveis do contexto organizacional que influencia o compartilhamento do conhecimento.

Por outro lado, houve uma série de pesquisas que trouxeram à tona a discussão sobre a influência dos aspectos culturais no processo de criação do conhecimento organizacional.

Angeloni e Grotto (2009) lançam mão de uma abordagem qualitativa para investigar a influência dos aspectos de cultura organizacional no compartilhamento de conhecimento entre os indivíduos de uma organização privada brasileira. Com base na amostra pesquisada, as autoras ressaltam a discussão em torno da promoção de uma cultura organizacional que estimule as práticas de gestão de conhecimento, concluindo que o aspecto cultural tanto pode ser um facilitador como uma barreira para o compartilhamento do conhecimento na organização.

Andreeva e Ikhilchik (2011) e Hong (2011) questionam haver uma validade universal em torno do processo de criação e compartilhamento do conhecimento. Ao resgatarem o aspecto social da criação do conhecimento (Nonaka \& Takeuchi, 1995), as discussões teóricas propostas por ambos os trabalhos criticam a predisposição assumida de que o processo de compartilhamento do conhecimento ocorre da mesma maneira, independentemente da carga 
cultural a que esteja submetido. O discurso desses autores incita para a importância de que a investigação a respeito da cultura não seja relacionada a uma eventual barreira ao processo de criação do conhecimento, mas sim como uma "lente" sob a qual o fenômeno se consolida em determinado ambiente organizacional.

Com um olhar atento às constantes demandas organizacionais por aumento de produtividade e redução e custos, Tseng (2010) e Hamel (2009) sugerem que a estrutura organizacional hierarquizada se constitui em um empecilho para o dinamismo presente na interação entre os indivíduos da organização. Sendo assim, com o objetivo de aprofundar a análise da relação entre hierarquia e criação do conhecimento organizacional, Tseng (2010) realiza um estudo de caso em duas organizações, amparado em uma abordagem mista, na qual em um primeiro momento foram realizadas entrevistas e, posteriormente, foi aplicado um questionário elaborado com base nos dados da própria entrevista, e na literatura pertinente à hierarquia, criação de conhecimento (Nonaka \& Takeuchi, 1995) e estratégias de gestão de conhecimento (Tseng, 2008).

A análise dos dados destaca o fato de que ao se estabelecerem metas estritas para uniformidade, eficiência e controle de processos, não necessariamente são proporcionadas condições facilitadoras para a fase de compartilhamento de conhecimento tácito. No entanto, este mesmo ambiente pode se tornar propício para a classificação e codificação do conhecimento, configurando-se como um contexto favorável para a combinação do conhecimento existente na organização.

Outras pesquisas evoluíram na discussão acerca de como as lideranças que coexistem no ambiente podem estabelecer algum tipo de relação com o processo de compartilhamento do conhecimento e, em outra perspectiva, como as lideranças podem assumir um papel de facilitadores e fomentadores de contextos que proporcionem o compartilhamento do conhecimento organizacional (Carmeli \& Waldman, 2009; Carmeli, Gelbard, \& Reiter-Palmon, 
2013; Vasconcelos, Mehri, Junior, \& Silva, 2013; von Krogh, Nonaka, \& Rechsteiner, 2012; Song, Kolb, Lee, \& Kim, 2012; Sveiby, 2007).

Ainda com a atenção voltada para a interação entre indivíduos no ambiente organizacional, Barbosa, Monteiro e Freitas (2012) realizam um estudo de caso, com abordagem qualitativa e finalidade descritiva, tendo como objetivo investigar se o compartilhamento do conhecimento em uma organização de grande porte do setor de varejo bancário ocorre em convergência com o modelo proposto por Tonet e Paz (2006).

Barbosa et al. (2012) descrevem o processo de compartilhamento de conhecimento utilizado pela organização com a metodologia "Fazer e Aprender" (FAZAP), por meio do processo de treinamento no ambiente de trabalho, em que se busca a aproximação dos indivíduos que necessitam de determinado conhecimento com aqueles que são possuidores de conhecimentos específicos sobre a realização de determinada atividade, serviço ou rotina.

Barbosa et al. (2012) utilizam uma amostra composta por oito indivíduos que participam como colaboradores da metodologia "Fazer e Aprender" e pertencem ao quadro de colaboradores alocados no setor de atendimento ao público em agências de varejo, sendo que três foram classificados como fontes de conhecimento ("multiplicadores corporativos"), pois são capacitados por meio de ações de treinamento coordenadas pela universidade corporativa da organização, enquanto os cinco restantes foram classificados como destinatários.

A partir dos resultados da análise de conteúdo a que foram submetidos os dados das respostas dos entrevistados, da pesquisa documental e da observação direta, Barbosa et al. (2012) categorizam o compartilhamento do conhecimento ocorrido com as fases do processo descritas por Tonet e Paz (2006).

Em relação à fase de iniciação, Barbosa et al. (2012) ressaltam a importância da análise das necessidades de conhecimento e de oportunidades para aquisição de conhecimentos diferentes ou novos e a localização das fontes de conhecimento como ações principais (Tonet 
\& Paz, 2006). Ambas as ações foram identificadas na organização pesquisada, além de algumas dificuldades enumeradas que foram identificadas, tais como as relacionadas ao contexto organizacional e às crenças e atitudes arraigadas na cultura organizacional que poderiam impactar o processo de compartilhamento.

No que diz respeito à fase de implementação, Tonet e Paz (2006) ressaltam a importância da promoção de interação entre fonte e destinatário e de planejamento do processo de compartilhamento, com a criação de estratégias e identificação de fatores que possam impactar negativamente no processo. De maneira convergente, Barbosa et al. (2012) constatam que as fontes transmissoras possuem as competências necessárias para a troca de conhecimentos; quanto às competências requeridas pelo destinatário, observou-se que a maioria dos entrevistados estavam dispostos a aprender sem apresentar resistências, sentindo-se confortáveis na situação de aprendizes, apresentando um comportamento colaborativo.

Ainda em relação à implantação, Tonet e Paz (2006) ratificam a relevância do planejamento para o sucesso do compartilhamento do conhecimento no ambiente organizacional. Todavia, por ocasião da análise dos dados, Barbosa et al. (2012) indicam que tal atividade não foi percebida pelos entrevistados como satisfatória, tendo sido justificado sua baixa ocorrência, devido à falta de tempo e à sobrecarga de atividades dos transmissores do conhecimento.

Com relação à fase de apoio (Tonet \& Paz, 2006), a análise dos dados realizada por Barbosa et al. (2012) sugere que esta fase não ocorreu em sua completude, tendo em vista a ausência de tempo disponível para a prática dos conhecimentos recém-compartilhados com os receptores.

Tonet e Paz (2006) tipificam incorporação do conhecimento compartilhado como sendo a aplicação prática do conhecimento no ambiente de trabalho. Desta forma, Barbosa et al. (2012) concluem que houve aplicação do conhecimento compartilhado, muito embora a 
necessidade por determinado conhecimento oscile constantemente, tendo em vista que a quantidade reduzida de trabalhadores, aliada a rotação de pessoal motivada pelo plano de aposentadorias e a falta de tempo, podem prejudicar a consolidação de uma cultura organizacional favorável ao compartilhamento do conhecimento.

Ainda que a pesquisa de Barbosa et al. (2012) tenha se limitado a analisar o compartilhamento do conhecimento organizacional com base no modelo de Tonet e Paz (2006), os resultados auferidos pelos pesquisadores suscitam questionamentos que proporcionam uma análise mais profunda da possível relação existente de alguns preditores com o compartilhamento do conhecimento, tais como as oportunidades criadas para a aquisição de novos conhecimentos e a importância de que sejam localizadas as principais fontes de conhecimento no ambiente interno da organização (Tonet \& Paz, 2006).

Em outra pesquisa, Lucchi, Bianco e Lourenção (2011) investigam como estagiários de engenharia de um programa de treinamento avançado de uma organização brasileira interagem em grupo com o auxílio de mentores, resultando na criação de conhecimento.

Sob uma abordagem qualitativa, Lucchi et al. (2011) realizam um estudo de caso instrumentados por entrevista e questionário aplicado aos estagiários e mentores. Com base em diversos autores especialistas em aprendizagem organizacional e gestão de conhecimento, a pesquisa elenca 18 conceitos que servem de base para a elaboração dos instrumentos sobre processo de compartilhamento e criação do conhecimento.

Lucchi et al. (2011) classificam a predominância dos conceitos da seguinte forma: (a) no nível micro - modelos mentais, habilidade, comunicação, autonomia, atenção, interesse, inteligência e gostar de ensinar; (b) no nível meso - comunicação, cooperação, trabalho em equipe, diálogo, relacionamento no ambiente, simulação de negócios, compartilhamento de visão, integração, compreensão mútua, prática e mentoring. 
Lucchi et al. (2011) caracterizam tais conceitos como sendo facilitadores e barreiras para a interação social, destacando o fato de que, em ambos os lados do processo de compartilhamento de conhecimento, neste caso o estagiário e o mentor, percebe-se a influência exercida pelas circunstâncias organizacionais.

Os resultados encontrados por Lucchi et al. (2011) corroboram a argumentação sustentada por Alves e Barbosa (2010), na qual se destaca que a ausência de processos estabelecidos para o compartilhamento do conhecimento é uma das principais barreiras encontradas nas organizações (Ipe, 2003).

Faoro e Oliveira (2014) realizam um estudo de caso de abordagem qualitativa, com o objetivo de analisar o compartilhamento de conhecimento intraorganizacional e interorganizacional em organizações privadas, tendo sido os dados coletados por meio de entrevistas semiestruturadas, documentos e observação direta.

Faoro e Oliveira (2014) citam Lim e Klobas (2000) para abordar o compartilhamento do conhecimento como a troca de experiências e ideias que pode ocorrer por meio de intranet e internet, fóruns estabelecidos de maneira formal ou informal, manuais, memoriais de processos e procedimentos adotados na organização, pesquisas, relatórios, reuniões formais e informais, dentre outras.

Com base na análise de dados coletados por meio de entrevistas com proprietários, diretores e gestores de duas grandes organizações privadas, Faoro e Oliveira (2014) constatam que as organizações investem em atividades de treinamento e capacitação, incentivando que os conhecimentos adquiridos sejam compartilhados dentro da equipe (Aurum, Daneshgar, \& Ward, 2008). Todavia, no que diz respeito à interação pessoal entre os indivíduos, os autores apontam que a interação entre os funcionários é realizada tanto por meios formais quanto informais, tais como conversas, reuniões, telefonemas e e-mail, ao ainda por outros sistemas de informação disponibilizados pela organização (Lim \& Klobas, 2000). 
Faoro e Oliveira (2014) destacam que em apenas uma das organizações foi observada a formalização dos processos (bem ou mal sucedidos), com o objetivo de que aquele conhecimento estivesse disponível para outros indivíduos e setores da organização. Contudo, em ambas as empresas ficaram evidenciadas que a alta administração aproveita as ideias dos seus funcionários para a melhoria e inovação dos seus processos produtivos.

No que diz respeito à estratégia de compartilhamento adotada, Faoro e Oliveira (2014) concluem que ambas as organizações pesquisadas são focadas no negócio, dando pouca ênfase aos processos de compartilhamento de conhecimento, especialmente no que diz respeito a sua formalização. Percebeu-se a predominância do compartilhamento por meio da personalização, ou seja, a ocorrência de conversas de trabalho e reuniões de maneira informal entre os indivíduos (Hansen \& Nohria, 1999).

Faoro e Oliveira (2014) resgatam a discussão da importância das ações de gestão de conhecimento utilizados pela alta administração, evidenciando que, ao relegar o processo apenas aos aspectos informais, corre-se o risco da diminuição da eficiência do processo de compartilhamento do conhecimento e, consequentemente, da manutenção da memória organizacional.

Alinhadas com a proposta metodológica adotada por Faoro e Oliveira (2014), percebese uma série de produções que utilizam a abordagem qualitativa para a análise do fenômeno, tais como as pesquisas de Andrade, Ferreira e Pereira (2010), Consentino et al. (2011) e Vasconcelos et al. (2013). No entanto, autores como Song, Yoon e Uhm (2012) argumentam que a exploração do fenômeno perpassa pela validação indutiva ou dedutiva de vários constructos que podem estar associados ao compartilhamento do conhecimento.

Desta forma, o desenvolvimento de escalas de mensuração, tais como as de Yang e Chen (2007) e Amayha (2013), podem contribuir para que a análise do compartilhamento do conhecimento organizacional possa ser complementada a partir das conclusões oriundas das 
pesquisas qualitativas (Song et al., 2012), ressaltando que tal processo deve estar amparado no rigor metodológico necessário para que se atinja, de forma simultânea, o alinhamento com a base teórica e os bons índices de confiabilidade, viabilizando a sua aplicação em outros contextos organizacionais.

A argumentação consolidada por esses autores indica que as ações de gestão de conhecimento adotadas pela administração das organizações podem proporcionar as condições e os meios para o compartilhamento do conhecimento, ou ainda viabilizar a criação de ambientes de interação social, nos quais surjam oportunidades para a criação, retenção e o compartilhamento do próprio conhecimento.

Conforme abordado nesta seção, o compartilhamento do conhecimento é desenvolvido com uma ampla possibilidade de teorizações e associações com outros construtos do ambiente organizacional. No entanto, com base nas justificativas previamente apresentadas, este estudo possui a intenção de descrever a relação existente entre as ações de gestão de conhecimento empregadas pela organização e o compartilhamento do conhecimento entre os indivíduos, conforme será abordado na próxima seção.

\subsection{Mecanismos de Aprendizagem e Compartilhamento do Conhecimento}

Conforme abordado nas seções anteriores, a discussão envolvendo o compartilhamento do conhecimento perpassa pela compreensão do aspecto social da interação entre os indivíduos no ambiente organizacional (Nonaka et al., 2000; von Krogh, Ichijo \& Nonaka, 2000). Nonaka et al. (2000) e von Krogh et al. (2000) sugerem que o debate seja ampliado para as circunstâncias organizacionais que proporcionem o compartilhamento e a criação do conhecimento, tais como os aspectos humano, culturais e contextuais da organização. 
Sob o contexto dessa teorização, esta seção aborda algumas produções teóricas e empíricas que tratam da influência das ações gerenciais materializadas por meio dos mecanismos de aprendizagem, as quais podem influenciar no compartilhamento do conhecimento organizacional.

Nonaka et al. (2000) e von Krogh et al. (2000) intensificam o foco em características vistas como fomentadoras para o surgimento de um ambiente propício ao compartilhamento do conhecimento, sendo tratadas como protagonistas as seguintes: a instauração da visão da organização voltada para o conhecimento; o gerenciamento e o incentivo para que as conversas produzidas entre os indivíduos sejam voltadas para o compartilhamento do conhecimento; gerenciamento dos ativistas do conhecimento, quais sejam, os indivíduos que mobilizam, coordenam e catalisam as atividades dentro do ambiente organizacional; a viabilização do contexto apropriado para que o conhecimento criado possa ser compartilhado; e o tratamento do conhecimento não apenas em sua forma abstrata, mas como um ativo que pode ser compartilhado entre os setores de uma organização.

As diversas condições levantadas por Nonaka et al. (2000) e von Krogh et al. (2000) constituem o pano de fundo da discussão trazida por autores como Senge (1993), Terra (2001) e Zellmer-Bruhn (2003), Borgatti e Cross (2003) e Nadler, Thompson e Van Boven (2003), os quais ratificam a importância da influência das ações de gestão de conhecimento no compartilhamento do conhecimento, por meio de mecanismos de aprendizagem.

Tais autores enfatizam que iniciativas da alta administração em reduzir as distâncias físicas e sociais dentro da organização possuem o potencial de fomentar condições de compartilhamento de conhecimento, tais como a interação social entre os indivíduos, o aprendizado por meio de observação, o acompanhamento na execução de tarefas, além da identificação dos experts em conhecimentos específicos na organização. 
Sob o contexto dessa discussão, algumas argumentações teóricas voltam a enfatizar a importância da análise da relação existente entre o compartilhamento do conhecimento com as seguintes variáveis: as condições proporcionadas pela organização (Nonaka \& von Krogh, 2009); os aspectos organizacionais que podem influenciar a criação e manutenção dos contextos capacitantes da organização (Tsoukas, 2009); a interação dos indivíduos dentro de um contexto capacitante proporcionado pela organização, considerando-se os seus componentes ativos e latentes (Argote \& Miron-Spektor, 2011); e as condições proporcionadas pela organização para a proliferação e legitimação das práticas dentro do contexto organizacional, e de como os indivíduos interagem e realizam as suas atividades sobre a influência dessas mesmas práticas (Gherardi, 2009).

Em consonância com a argumentação de tais autores, Yang e Chen (2007) traçam o objetivo de investigar a relação entre as capacidades de conhecimento organizacional (Organizational Knowledge Capabilities-OKC) e o compartilhamento do conhecimento. Com base em uma amostra de indivíduos com diferentes posições hierárquicas em indústrias de Taiwan (n=256), Yang e Chen (2007) realizam uma análise de regressão para examinar as formas como as capacidades de conhecimento organizacional podem impulsionar o compartilhamento de conhecimento.

Ao se aproximar da teoria da firma baseada em recursos (Barney, 1991; DiFillipe, 1991), Yang e Chen (2007) definem capacidades de conhecimento organizacional como sendo os recursos empregados pela organização para que as características do conhecimento, os aspectos culturais e estruturais da organização, além dos aspectos de relacionamento entre os indivíduos, contribuam para que ocorra o processo de criação, aquisição, compartilhamento e aplicação do conhecimento na organização. 
Com base em uma vasta revisão de literatura, Yang e Chen (2007) delimitam quatro capacidades de conhecimento organizacional: cultural, estrutural, humana e técnica, conforme Tabela 5.

Tabela 5

Síntese das capacidades de conhecimento organizacional

\begin{tabular}{cl}
\hline Variável & \multicolumn{1}{c}{ Definição } \\
\hline $\begin{array}{c}\text { Cultura de } \\
\text { conhecimento }\end{array}$ & $\begin{array}{l}\text { É a característica da organização de suportar a valorização e a criação de novos conhecimentos } \\
\text { na organização, por meio de interações em um ambiente colaborativo entre os indivíduos. }\end{array}$ \\
\hline $\begin{array}{c}\text { Estrutura de } \\
\text { conhecimento }\end{array}$ & $\begin{array}{l}\text { É a característica da organização de integrar normas, políticas, o contexto e um sistema de } \\
\text { incentivos dentro da organização, com o objetivo de proporcionar a criação e o } \\
\text { compartilhamento do conhecimento. }\end{array}$ \\
\hline $\begin{array}{c}\text { Conhecimento } \\
\text { humano }\end{array}$ & $\begin{array}{l}\text { É a característica da organização em incentivar e promover a compreensão do relacionamento } \\
\text { interpessoal entre os indivíduos da organização. }\end{array}$ \\
\hline $\begin{array}{c}\text { Conhecimento } \\
\text { técnico }\end{array}$ & $\begin{array}{l}\text { É a capacidade de a organização de integrar e desenvolver conhecimento por meio da } \\
\text { utilização eficiente de tecnologias de informação e comunicação. }\end{array}$ \\
\hline Nota. Fonte: Adaptado de Yang e Chen (2007).
\end{tabular}

A análise dos resultados da análise fatorial realizada por Yang e Chen (2007) aponta para a explicação de $72,2 \%$ da variância acumulada. Dentre os quatro fatores da Tabela 5, o conhecimento técnico $(\alpha=0.8514)$ explicou a maior porção, sendo responsável por $43,9 \%$ da variância, apresentando-se como o fator mais relevante. Em segundo lugar aparece a cultura de conhecimento $(\alpha=0.8611)$, responsável por $15,4 \%$ da variância. O terceiro fator é estrutura de conhecimento ( $\alpha=0.8215)$ associado a $6,9 \%$ e, por fim, o conhecimento humano $(\alpha=0.8331)$, respondendo por $6,1 \%$ da variância.

Em relação ao teste da hipótese "organizações que implementam um sistema de gestão de conhecimento são mais participativas no compartilhamento de conhecimento do que as organizações que não implementam”, os resultados apontam que a contribuição média de cada fator (com exceção do fator conhecimento técnico) é significativamente maior no grupo que possui um sistema de gestão de conhecimento. Ou seja, levando-se em consideração a amostra pesquisada, a implantação da gestão de conhecimento pode impulsionar o processo de compartilhamento de conhecimento, com base nos fatores associados às capacidades de conhecimento cultural, estrutural e humana. 
Posteriormente, Yang e Chen (2007) realizam uma análise de regressão múltipla, na qual, em um primeiro momento, analisam a influência da capacidade de conhecimento organizacional (variável independente) sobre o compartilhamento do conhecimento (variável dependente). Os resultados indicam que a capacidade organizacional está significativamente relacionada com o compartilhamento do conhecimento $(\beta=0.645, t=13.209, \mathrm{p}<0.001)$.

Em seguida, Yang e Chen (2007) demonstram que as capacidades técnicas $(\beta=0.250$, $t=5.080, \mathrm{p}<0.001)$, estrutural $(\beta=0.190, t=2.974, \mathrm{p}<0.01)$ e humanas $(\beta=0.263, t=4.188$, $\mathrm{p}<0.001)$ são capazes de influenciar em níveis significativamente relevantes o compartilhamento do conhecimento, exceção feita ao aspecto cultural $(\beta=0.134, t=1.964$, $\mathrm{p}<0.051)$.

Por fim, Yang e Chen (2007) realizam uma análise comparativa entre firmas que possuem e que não dispõem de um sistema de gestão de conhecimento. Os autores concluem que apenas a capacidade técnica é positivamente associada ao compartilhamento de conhecimento $(\beta=0.253, t=3.975, \mathrm{p}<0.001)$ para as firmas que não o possuem, não tendo sido apresentada relação significativa com as demais variáveis citadas na Tabela 5.

A pesquisa de Yang e Chen (2007) contribui para a análise dos fatores que podem influenciar no compartilhamento organizacional, ainda que a sua análise tenha considerado o compartilhamento do conhecimento como um único fator, ou seja, não foram consideradas as possíveis estruturas subjacentes a este construto, especificamente.

Por outro lado, Isidro-Filho (2009) enfatiza os múltiplos fatores organizacionais que podem influenciar na aquisição, criação e compartilhamento do conhecimento organizacional (Lipshitz et al., 2002). De forma convergente à Lipshitz et al. (2002) e Lipshitz e Popper (1996), Isidro-Filho (2009) desenvolve o entendimento sobre mecanismos de aprendizagem como sendo os aspectos essenciais para o fomento de práticas individuais e organizacionais que proporcionem atividades de gestão de conhecimento no ambiente da organização. 
Isidro-Filho (2009) adota uma perspectiva cognitiva, na qual o processo de aprendizagem consiste em permitir que a organização processe, interprete e responda as informações provenientes do ambiente interno e externo, viabilizando a consolidação de maneiras que suportem a aprendizagem organizacional dos indivíduos para a canalização do compartilhamento do conhecimento para a tomada de decisão. O autor define mecanismos de aprendizagem como sendo a criação de procedimentos e a viabilização de práticas que permitam a aquisição, análise, armazenamento, compartilhamento e utilização dos conhecimentos da organização.

Conforme abordado em seção anterior, Isidro-Filho (2009) aproxima a definição de mecanismos de aprendizagem das ações de gestão de conhecimento, considerando a possibilidade de que tais mecanismos sejam compreendidos como fases deste processo de gestão. Sob influência do trabalho de López et al. (2005), o autor classifica os mecanismos de aprendizagem da seguinte maneira: aquisição externa e interna, a qual ocorre por meios de ações que proporcionem a obtenção de conhecimentos relevantes para os objetivos organizacionais; distribuição, a qual se refere à maneira como o conhecimento é compartilhado na organização; interpretação, relativa à incorporação e compartilhamento de conhecimentos, proporcionando uma leitura do ambiente que ampare a tomada de decisões; e a memória organizacional, que se refere à forma como a organização armazena o seu conhecimento com vistas à utilização futura.

Com base na Escala de Mecanismo de Aprendizagem em Organizações (EMAO) desenvolvida por López et al. (2005), Isidro-Filho (2009) realiza um trabalho de adaptação dessa escala, a qual tem o objetivo de coletar dados sobre os mecanismos de aprendizagem baseado nas quatro dimensões citadas anteriormente: aquisição, distribuição, interpretação e memória organizacional. Após a realização da tradução da escala por especialistas e a adoção e critérios que minimizassem os aspectos de linguagem, ambiguidade e viés (Gunther, 1999), 
chegou-se a uma escala adaptada com 22 itens, a qual foi aplicada em 522 funcionários de uma instituição financeira com sede em Brasília-DF.

Para a realização do processo de adaptação da escala, Isidro-Filho (2009) adota procedimentos preconizados na literatura de modo que sejam preservadas a validade e fidedignidade dos instrumentos de pesquisa (Pasquali, 1997). Os índices encontrados na pesquisa demonstram que foi obtido o Kaiser-Meyer-Olkin (KMO) de 0,92 (p>0,000), ao mesmo tempo em que o total da variância explicada foi de 49,62\%. Após a análise fatorial, não houve qualquer item que tenha apresentado carga fatorial abaixo de 0,35 para os fatores extraídos.

A escala adaptada por Isidro-Filho (2009) apresentou constituição diferente da versão original elaborada por López et al. (2005), pois enquanto esta é composta por 4 fatores, a escala adaptada é constituída por 3 fatores, estabelecidos da seguinte forma: Fator 1 -Aquisição Interna e Externa de Conhecimentos, o qual foi definido como "conjunto de ações organizacionais de busca de conhecimento no ambiente interno e externo que favorecem aprendizagem na organização", apresentando alpha de Cronbach de 0,81 e cargas fatoriais entre 0,45 e 0,69; Fator 2 - Compartilhamento de Conhecimento - foi definido como as "ações baseadas em relações de troca social entre membros de uma equipe/organização, em que conhecimento e experiências são compartilhados e contribuem para a aquisição de novos comportamentos e atitudes que podem impactar positivamente o desempenho do trabalho", com alpha de Cronbach de 0,87 e itens com carga fatorial entre 0,39 e 0,65; por fim, o Fator 3 - Codificação e Controle do Conhecimento foi definido como sendo o "conjunto de bases de dados para armazenamento e gestão de conhecimentos e experiências relevantes que favorecem o acesso e utilização desses recursos por parte dos funcionários da organização", atingindo o alpha de Cronbach de 0,71 e cargas fatoriais entre 0,36 e 0,73. 
Isidro-Filho (2009) ressalta que apesar dos altos alpha de Cronbach atingidos, os resultados da pesquisa deixam a possibilidade para que sejam aperfeiçoados alguns itens, com o objetivo de melhorar suas respectivas cargas fatoriais, o que resultaria na maior fidedignidade, principalmente do Fator 3 - Codificação e Controle do Conhecimento. Porém, mesmo com essas ressalvas apontadas pelo autor, é possível observar que esse trabalho aborda os principais aspectos tratados na literatura de gestão de conhecimento, alinhada com a argumentação de autores como Daveport e Prusak (1998), Probst et al. (2002), Heisig (2009), Xavier et al. (2012) e Hartung e Oliveira (2013).

De maneira convergente, Moresi e Mendes (2010) realizam uma pesquisa qualitativa, na qual é reafirmada a perspectiva de que as ações de gestão de conhecimento proporcionadas pelos líderes formais e pelos gerentes da administração emergem como o principal fator de influência para o compartilhamento do conhecimento. Moresi e Mendes (2010) expõem de forma categórica que mesmo havendo vontade e interesse em compartilhar conhecimento, é preciso que haja também condições e orientações técnicas para que tal compartilhamento realmente ocorra.

Ainda com o foco nas iniciativas assumidas pelas organizações, Sá, Bento, Ziviani e Ferreira (2013) resgatam Terra (2001) ao afirmar que a gestão do conhecimento sugere a adoção de ações gerenciais adequadas aos processos de criação e aprendizado individual, bem como a viabilização de mecanismos e arranjos sistêmicos que tratem o nível individual, estratégico e operacional.

Com o objetivo de analisar as ações de gestão do conhecimento adotadas em algumas organizações mineiras, Sá et al. (2013) lançam mão de uma abordagem quantitativa, por meio da aplicação de um instrumento elaborado com base nas sete dimensões da prática gerencial abordadas por Terra (2001), apresentadas em seções anteriores. 
A análise fatorial foi utilizada para a análise dos dados provenientes de questionários obtidos de duas empresas: uma do setor da indústria siderúrgica, e outra do setor de tecnologia da informação, sendo ambas as organizações localizadas em Belo Horizonte-MG. Como frutos da análise realizada emergiram os seguintes fatores: política cultural corporativa, políticas de recursos humanos, estratégia e comunicação organizacional, estratégias do conhecimento, estímulo à aprendizagem, clima organizacional e feedback, mensuração das capacidades e resultados, e acesso à informação.

Os resultados obtidos evidenciaram a adequação da análise fatorial, tendo sido constatados índices em conformidade com a literatura especializada. Os oito fatores que emergiram da escala responderam por $65,2 \%$ da variância, ratificando a precisão alcançada, tendo em vista o aspecto social da realização da pesquisa (Hair, Black, Babin, Anderson, \& Tatham, 2010). Em relação à consistência interna das variáveis que compõem a escala, o alpha de Cronbach atingiu o valor de geral de 0,895 .

Os resultados da pesquisa de Sá et al. (2013) revelam que a organização pesquisada não possui totalmente sedimentadas as ações que envolvem a gestão do conhecimento. Os autores reforçam a necessidade de que sejam aprofundadas as discussões relativas à gestão do conhecimento, considerando-se a complexidade que envolve a viabilização de condições que proporcionem a aquisição, a criação, o compartilhamento e a retenção de conhecimento.

A consolidação do referencial teórico apresentado nesta investigação permite com que seja elaborada a Figura 1, na qual é representada visualmente a influência existente entre a gestão de conhecimento, constituída pelas ações de identificação, criação, compartilhamento, utilização e armazenamento do conhecimento, e o comportamento de compartilhamento de conhecimento entre os indivíduos no ambiente organizacional.

O estabelecimento da estrutura conceitual da Figura 1 configura a relação preditiva a ser testada com base nos procedimentos descritos na próxima seção. 
Mecanismos de Aprendizagem (Ações de Gestão de Conhecimento)

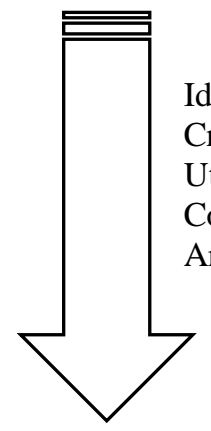

Identificação

Criação

Utilização

Compartilhamento

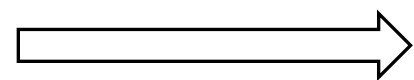

Compartilhamento

Armazenamento

do Conhecimento

Figura 1. Estrutura conceitual.

Fonte: Elaborado pelo Autor. 


\section{MÉTODOS E TÉCNICAS DE PESQUISA}

Além de abordar a descrição da pesquisa realizada, a população a ser pesquisada, os instrumentos de pesquisa utilizados e os procedimentos de análise de dados, esta seção se inicia com uma breve contextualização sobre os aspectos filosóficos que permeiam as opções metodológicas assumidas, conforme será pontuado a seguir.

\subsection{Concepções Filosóficas e Paradigmáticas}

A primeira coisa a se fazer é delimitar o conceito de concepção e paradigma. Para a condução dessa investigação, optou-se por conceber a definição de concepção como sendo o conjunto de crenças e verdades justificadas que amparam determinada ação (Guba, 1990).

No que diz respeito ao conceito de paradigmas, Godoi, Bandeira-de-Melo e Silva (2010) afirmam que paradigma é um conjunto de crenças, valores e técnicas compartilhadas pelos integrantes de uma comunidade científica, reconhecidas amplamente, e que, por certo lapso temporal, proporcionam problemas e soluções pela maneira de enxergar e analisar os fenômenos.

Ainda que a pesquisa não tenha intenção de realizar uma revisão conceitual mais aprofundada, o resgate de ambas as definições é oportuno, pois as concepções e paradigmas amparam a visão de mundo e, mais especificamente, a lupa a ser utilizada para a análise do fenômeno (Godoi et al., 2010).

Sendo assim, para efeito dessa investigação foi identificada convergência com as concepções funcionalistas, tendo em vista que tal epistemologia busca a explicação e análise dos acontecimentos do ambiente social por meio das possíveis relações existentes entre as 
variáveis do ambiente, além de considerar o comportamento do indivíduo como algo moldado pelo contexto estabelecido pelas relações sociais admitidas (Burrel \& Morgan, 1979).

\subsection{Estratégia Metodológica}

O método escolhido para a condução desta pesquisa é o levantamento, pois a aproximação com o fenômeno se dará por meio da obtenção de dados provenientes de uma amostra específica de uma população (Freitas, Oliveira, Saccol, \& Moscarola, 2000), utilizando-se como instrumento um questionário adaptado sobre o construto "Mecanismo de Aprendizagem" e uma escala desenvolvida no âmbito dessa pesquisa sobre o construto compartilhamento do conhecimento. A utilização de tal método se ampara na definição prévia do instrumento a ser utilizado, bem como na intenção em retratar de forma quantitativa as possíveis relações existentes entre as variáveis.

Quanto aos objetivos gerais a serem alcançados com a realização de uma pesquisa de levantamento, esta pesquisa assume contornos descritivos, os quais dizem respeito à intenção de descrever as características de determinado fenômeno, por meio do estabelecimento de relações entre variáveis, utilizando-se de técnicas padronizadas de coleta de dados (Andrade, 2002). Triviños (1987) acrescenta que a pesquisa descritiva prima pela delimitação precisa de técnica, métodos, modelos e teorias que amparem a coleta e interpretação de dados, proporcionando validade científica à pesquisa.

O método proposto para a presente pesquisa é amparado em uma abordagem quantitativa, na qual o objetivo é identificar empiricamente a influência de mecanismos de aprendizagem (variável independente) sobre o compartilhamento do conhecimento organizacional (variável dependente). 
De forma convergente a Lipshitz et al. (2002) e Isidro-Filho (2009), esta pesquisa propõe a conciliação conceitual entre as ações de gestão de conhecimento e os mecanismos de aprendizagem, adotando a definição de tais mecanismos como sendo "os arranjos e procedimentos institucionalizados utilizados pela organização para coletar, analisar, armazenar, disseminar e utilizar conhecimentos essenciais para seu desempenho e de seus membros" (Isidro-Filho, 2009).

No que diz respeito à variável dependente, o compartilhamento do conhecimento é definido no contexto dessa pesquisa como sendo "o intercâmbio de conhecimento por meio de interações sociais em ambientes físicos ou virtuais, ou de acesso a repositórios da organização, de forma que ocorra a compreensão do conhecimento compartilhado" (Nonaka \& Takeuchi, 1995; Nonaka \& Konno, 1998; Nonaka et al., 2000; Szulanski, 2000; Bartol \& Srivastava, 2002; Probst et al., 2002; Tonet \& Paz, 2006; Hartung \& Oliveira, 2013).

No que tange à opção por tal método de pesquisa, esta escolha perpassa pelas justificativas de sua adoção, a população e a amostra envolvidas, a concepção do instrumento utilizado, o relacionamento entre as variáveis e o tipo de análise de dados a ser empregado.

As justificativas para a realização de um levantamento encontram respaldo nas considerações de Babbie (1990), de que a condução de uma investigação com tal método proporciona a possibilidade de se realizar uma inferência em relação ao comportamento da relação das variáveis no contexto da população estudada.

Complementarmente à ideia anterior, a opção por dados provenientes do levantamento é amparada em circunstâncias que direcionam este método para a presente pesquisa. Considerase a importância de que sejam quantificadas numericamente as tendências, atitudes e opiniões, de uma amostra populacional delimitada, por meio da padronização na forma de coleta dos dados, diminuindo-se o risco de não se conseguir comparar o material coletado (Creswell, 2010). 
Ressalta-se ainda que a realização do levantamento é de corte transversal, o qual Hair, Babin, Money e Samounel (2005) descrevem como sendo aquele em que se observa o fenômeno em um ponto determinado do tempo. No que diz respeito à elaboração dos instrumentos, optouse por tomar como base uma escala validada sobre mecanismos de aprendizagem (Isidro-Filho, 2009), além do desenvolvimento de uma escala sobre compartilhamento de conhecimento, sob as justificativas que serão tratadas oportunamente.

\subsection{Organizações Pesquisadas}

O contexto desta pesquisa ocorre dentro da Administração Direta Federal. Nessa perspectiva, Gelis Filho (2006) conceitua Administração Direta como sendo os serviços integrados na estrutura administrativa da Presidência da República (ministérios), sendo, pois, tais organizações subordinadas hierarquicamente à direção do órgão ao qual estejam vinculadas.

Gelis Filho (2006) destaca que a diferença entre a Administração Direta e a Indireta é que, nesta última, as organizações são associadas ao órgão superior, mantendo certo grau de autonomia, tais como autarquias e fundações (direito público) e sociedades de empresas mistas e estatais (direito privado), o que não acontece na Administração Direta.

Com base neste entendimento, e tendo como objetivo obter a maior variabilidade de possíveis respondentes, tendo em vista a intenção de diminuir vieses nos resultados encontrados (Donaldson \& Grant-Valone, 2002), o grupo de organizações pesquisadas foi composto por organizações civis e militares, escolhidas por critério de acessibilidade.

As organizações militares pesquisadas possuem missões distintas. No âmbito dessa pesquisa tais organizações foram denominadas, de forma fictícia, como organizações Alpha, Bravo e Charlie. 
As organizações Alpha e Delta são responsáveis pelo gerenciamento do processo de aquisições de sistemas complexos de defesa. A organização Bravo é responsável por coordenar ações de ensino, por meio da administração das atividades que envolvam as suas respectivas escolas de formação continuada. Por fim, a organização Charlie é responsável por ações de recursos humanos, no que diz respeito ao dimensionamento da necessidade de tais recursos, bem como a sua posterior alocação de acordo com as suas competências específicas.

O grupo de organizações civis foi composto por organizações com competências e atividades associadas às políticas sociais, de acordo com o Decreto $\mathrm{n}^{\mathrm{o}} 7.191$, de 31 de maio de 2010, tais como Ministério da Cultura, Ministério da Educação, Ministério da Justiça, Ministério da Pesca e Aquicultura, Ministério da Previdência Social, Ministério da Saúde, Ministério das Cidades, Ministério do Desenvolvimento Agrário, Ministério do Desenvolvimento Social e Combate à Fome, Ministério do Trabalho e Emprego, Secretária de Direitos Humanos, Secretaria de Políticas de Promoção da Igualdade Racial, Secretaria de Políticas para as Mulheres.

No que diz a opção por todas as organizações pesquisadas, não se buscou analisar previamente se tais organizações possuíam, ou não, um setor específico responsável pelas ações de gestão de conhecimento. Amparado nas argumentações de Davenport e Prusak (1998) e Alvarenga Neto (2008), nas quais são reafirmadas a existência de ações de gestão de conhecimento emanadas pela alta administração da administração, ainda que de forma intuitiva por estas, optou-se por não categorizar as organizações quanto a tais aspectos.

Por outro lado, ainda que alguns autores tenham abordado temas que associem o compartilhamento de conhecimento com o tipo de estrutura organizacional (Frost, Birkinshaw, \& Ensign, 2002), ou ainda o nível da hierarquia presente no ambiente (Hamel, 2009; Tseng, 2010;), a presente pesquisa não tem como objetivo se ater à teorização sobre as diferenças de tais grupos de organizações, pois, ao contrário, vê em tais diferenças a possibilidade de se obter 
a maior variabilidade de dados, permitindo a análise das interações dos indivíduos no ambiente público, conforme será detalhado a seguir.

\subsection{Pesquisados}

A delimitação da população nas organizações militares adotou a premissa de não priorizar apenas gerentes e diretores, em detrimento às pessoas que apenas executam e cumprem os regulamentos e diretrizes estabelecidas por seus superiores.

Desta forma, ao dar voz a todos os integrantes da organização, independentemente do grau hierárquico e do nível de escolaridade, buscou-se capturar a percepção de Diretores, Presidentes, Gerentes e Técnicos das organizações militares descritas no item anterior. Ainda que respeitadas as funções delimitadas pelos níveis hierárquicos e pelas competências de cada indivíduo, todos os respondentes trabalham em atividades afins, conforme listado abaixo:

$\checkmark$ Os respondentes da organização Alpha desenvolvem ações relacionadas à condução do processo de aquisição de novos sistemas de defesa, as quais envolvem a solicitação, o recebimento, a análise e a seleção da melhor proposta comercial e técnica para a aquisição de novos sistemas de defesa.

$\checkmark$ Os integrantes da organização Bravo realizam ações de planejamento, monitoramento e controle, das atividades de ensino das escolas de formação continuada, incluindo todo o processo de admissão por meio de concurso público para o preenchimento dos diversos quadros e carreiras estabelecidos.

$\checkmark$ Os integrantes da organização Charlie desenvolvem atividades relacionadas a planejamento, monitoramento e controle do fluxo de carreira do pessoal, no que diz respeito aos estudos para correto dimensionamento e alocação dos recursos humanos, frente às necessidades de manutenção da capacidade operacional e funcional a serem mantidas. 
No que tange à organização Delta, de forma semelhante à organização Alpha, seus integrantes desempenham atividades relacionadas à solicitação, o recebimento, a análise e a seleção da melhor proposta comercial e técnica para a aquisição de novos sistemas de defesa.

Em relação às organizações civis, intencionava-se utilizar o mesmo método de seleção da população. Todavia, em função das dificuldades para a autorização da aplicação do instrumento de pesquisa em todos os níveis funcionais das organizações, optou-se por delimitar a população aos Analistas Técnicos de Políticas Sociais (ATPS) das organizações listadas no item 3.3, tendo em vista a possibilidade de acesso a esta população de servidores.

Em relação aos ATPS, a Lei n 12.094, de 19 de novembro de 2009, estabelece que esses servidores possuam como atribuição legal o desenvolvimento de atividades especializadas de assistência técnica em projetos e programas na área de saúde, previdência, emprego e renda, segurança pública, desenvolvimento urbano, segurança alimentar, assistência social, educação, cultura, cidadania, direitos humanos e proteção à infância e juventude, ao portador de necessidades especiais, ao idoso e ao indígena.

Desta forma, a adoção dos critérios para a delimitação das características da população de respondentes segue o preconizado por Creswell (2010), em relação aos seguintes aspectos: tamanho da população; o número de respondentes; o meio de acesso; e, por fim, a forma de seleção da amostra, no que diz respeito aos aspectos de aleatoriedade, estratificação ou envolvimento de todos os indivíduos da organização. Tais aspectos se encontram resumidos na Tabela 6.

Tabela 6

Síntese da população e da amostra pesquisadas

\begin{tabular}{cccccc}
\hline Org. & $\begin{array}{c}\text { Tamanho da } \\
\text { População }\end{array}$ & $\mathrm{N}^{\mathbf{o}}$ de Respondentes & Taxa de Resposta $(\%)$ & Acesso & Seleção Aleatória \\
\hline Alpha & 207 & 125 & 60,40 & Email & Sim \\
\hline Beta & 85 & 41 & 48,25 & Email & Sim \\
\hline Charlie & 108 & 25 & 23,15 & Email & Sim \\
\hline Delta & 50 & 16 & 32,00 & Email & Sim \\
\hline
\end{tabular}




\begin{tabular}{cccccc}
\hline Ministérios & 400 & 61 & 15,25 & Email & Não \\
\hline TOTAL & 850 & 268 & 31,55 & Email
\end{tabular}

Nota. Fonte: Dados da Pesquisa.

Em relação aos aspectos de seleção da amostra, todos os integrantes das organizações Alpha, Beta, Charlie e Delta tiveram a oportunidade de participar da pesquisa por meio dos emails funcionais, caracterizando esta parcela da amostra como censitária (Creswell, 2010).

No que diz respeito à amostra dos Ministérios, ressalta-se que apenas os funcionários ATPS tiveram acesso à pesquisa, devido aos motivos explicados anteriormente. Ademais, apenas tiveram oportunidade de responder o questionário os ATPS que possuíam cadastro na Associação Nacional da Carreira de Desenvolvimento de Políticas Sociais (ANDEPS). Sendo assim, esta parte da amostra foi considerada não aleatória, tendo em vista a sua seleção haver sido feita pelo critério de acessibilidade (Creswell, 2010).

A compreensão da amostra de respondentes permite que se avance para os critérios que nortearam a elaboração dos instrumentos, como será visto a seguir.

\subsection{Instrumentos de pesquisa}

Para a consecução do objetivo dessa pesquisa foi delineada a necessidade de adoção de duas escalas de medida: uma escala para mensurar a percepção dos indivíduos quanto às ações de gestão de conhecimento proporcionadas pela organização (mecanismos de aprendizagem); e uma escala que mensurasse o compartilhamento do conhecimento que ocorre como fruto da interação entre os próprios indivíduos.

Em ambos os casos as escalas foram elaboradas com base em uma revisão sistemática da literatura sobre o tema, tendo os seus itens passado por um processo de validação semântica e teórica por meio da ação de especialistas, além da aplicação de um teste piloto do questionário em uma pequena amostra, de forma que fossem levantados eventuais desvios semânticos 
(Pasquali, 1997). Todos esses procedimentos abordados na literatura têm o objetivo de viabilizar com que a adaptação realizada em uma escala e o desenvolvimento da outra proporcionem instrumentos com bons parâmetros de validade e de fidedignidade (Pasquali, 1997).

A escala de mecanismos de aprendizagem foi desenvolvida com base na Escala de Mecanismo de Aprendizagem em Organizações (EMAO), elaborada por López et al. (2005), e adaptada por Isidro-Filho (2009) para a língua portuguesa, conforme apresentado anteriormente. A opção por ter a escala adaptada de Isidro-Filho (2009) como ponto de partida se deu em virtude da sua elaboração ter sido calcada na perspectiva teórica de mecanismos de aprendizagem de Lipshitz e Popper (1996) e Lipshitz et al. (2002), a qual possui consonância com os conceitos de ações de gestão de conhecimento pontuadas por Davenport e Prusak (1998), Probst et al. (2002) e Hartung e Oliveira (2013), conforme explicitada na Tabela 7.

Tabela 7

Síntese da EMAO.

\begin{tabular}{|c|c|c|}
\hline \multicolumn{3}{|l|}{ Fator 1 - Aquisição Interna e Externa de Conhecimento (alpha=0,81) } \\
\hline Descrição do Item & $\begin{array}{c}\text { Carga } \\
\text { Fatorial }\end{array}$ & $\mathrm{H}^{2}$ \\
\hline $\begin{array}{l}\text { - A organização incentiva seus funcionários a participar de redes e grupos externos } \\
\text { de pessoas tanto formais quanto informais. }\end{array}$ & 0,69 & 0,61 \\
\hline $\begin{array}{l}\text { - A organização promove parcerias com outras organizações, universidades, escolas } \\
\text { técnicas e etc. }\end{array}$ & 0,63 & 0,69 \\
\hline - A organização mantém contato com profissionais e especialistas externos. & 0,58 & 0,51 \\
\hline - A organização promove apoia inovações. & 0,51 & 0,50 \\
\hline $\begin{array}{l}\text { - A organização oferece oportunidades de aprendizagem, tais como programas } \\
\text { internos de treinamento, visitas a outros departamentos e etc. }\end{array}$ & 0,48 & 0,43 \\
\hline $\begin{array}{l}\text { - A organização identifica experts ou assuntos específicos por meio de catálogos ou } \\
\text { e-mails arquivados de acordo com os assuntos aos quais pertencem. }\end{array}$ & 0,46 & 0,61 \\
\hline $\begin{array}{l}\text { - Os membros de minha equipe participam de eventos externos (congressos, feiras, } \\
\text { simpósios e etc.) }\end{array}$ & 0,45 & 0,38 \\
\hline \multicolumn{3}{|l|}{ Fator $2-$ Compartilhamento de Conhecimentos $($ alpha $=0,87)$} \\
\hline Descrição do Item & $\begin{array}{c}\text { Carga } \\
\text { Fatorial }\end{array}$ & $\mathrm{H}^{2}$ \\
\hline - Os membros de minha equipe compartilham do mesmo objetivo. & 0,65 & 0,61 \\
\hline $\begin{array}{l}\text { - Os funcionários de minha equipe compartilham conhecimentos e experiências por } \\
\text { meio de diálogos com os demais colegas de trabalho. }\end{array}$ & 0,62 & 0,69 \\
\hline $\begin{array}{l}\text { - Funcionários da equipe a que pertenço coletam, classificam e distribuem sugestões } \\
\text { internas dos demais membros. }\end{array}$ & 0,59 & 0,55 \\
\hline - O trabalho em equipe é uma prática comum na organização. & 0,53 & 0,51 \\
\hline $\begin{array}{l}\text { - Novas ideias e abordagens sobre desempenho no trabalho são aplicadas no dia-a- } \\
\text { dia de minha equipe. }\end{array}$ & 0,50 & 0,49 \\
\hline
\end{tabular}




\begin{tabular}{|c|c|c|}
\hline - Os funcionários são informados a respeito dos objetivos da organização. & 0,48 & 0,46 \\
\hline $\begin{array}{l}\text { - Encontros são realizados para informar os funcionários a respeito das últimas } \\
\text { inovações na organização }\end{array}$ & 0,47 & 0,49 \\
\hline $\begin{array}{l}\text { - A organização desenvolve programas internos de rodízio de tarefas e mudança de } \\
\text { funcionários entre departamentos e funções. }\end{array}$ & 0,42 & 0,42 \\
\hline $\begin{array}{l}\text { - A organização tem mecanismos formais que garantem o compartilhamento de } \\
\text { melhores práticas entre as diferentes áreas de atividade. }\end{array}$ & 0,41 & 0,55 \\
\hline $\begin{array}{l}\text { - Funcionários da equipe a que pertenço participam de outras equipes ou unidades e } \\
\text { atuam como elos entre elas }\end{array}$ & 0,39 & 0,32 \\
\hline \multicolumn{3}{|l|}{ Fator 3 - Codificação e Controle de Conhecimentos $(a l p h a=0,71)$} \\
\hline Descrição do Item & $\begin{array}{c}\text { Carga } \\
\text { Fatorial }\end{array}$ & $\mathrm{H}^{2}$ \\
\hline - As bases de dados utilizadas por minha equipe são atualizadas. & 0,73 & 0,68 \\
\hline $\begin{array}{l}\text { - As bases de dados da organização são consultadas por meio de alguns tipos de } \\
\text { redes (Lotus Notes, intranet, etc). }\end{array}$ & 0,61 & 0,59 \\
\hline - A organização conta com base de dados atualizada referente a seus clientes. & 0,60 & 0,58 \\
\hline $\begin{array}{l}\text { - A organização tem base de dados para armazenar suas experiências e } \\
\text { conhecimento. }\end{array}$ & 0,36 & 055 \\
\hline
\end{tabular}
Nota. Fonte: Isidro-Filho (2009).

Os 22 itens amparados em uma escala Likert de 5 pontos (de 1-nunca ocorre a 5-sempre ocorre) da escala de López et al. (2005), adaptada por Isidro-Filho (2009), foram distribuídos em uma estrutura de três fatores, os quais explicaram 49,62\% da variância total das respostas dos respondentes.

A adoção da EMAO como base para a elaboração da escala de mecanismos de aprendizagem foi amparada em algumas das sugestões destacadas por Isidro-Filho (2009), tais como a possibilidade de que os itens da escala fossem submetidos a um novo processo de validação semântica, além da elaboração de novos itens como base na teoria pertinente, o que poderia acarretar na melhora das cargas fatoriais e da fidedignidade do instrumento.

Além disso, em uma análise preliminar, detectou-se a necessidade de que os itens relacionados ao fator "Compartilhamento de Conhecimento" fossem readequados no sentido de contextualizar os itens como uma ação proporcionada pela organização. Sem que esta ação fosse tomada, ter-se-ia a impressão de que os itens deste fator retratam o próprio fenômeno de compartilhamento do conhecimento, e não uma condição proporcionada pela organização para que este ocorra. 
A análise conduzida por Isidro-Filho (2009) realizou a rotação dos fatores de forma ortogonal, utilizando-se do método varimax, o qual sugere ser nula a correlação entre os fatores $(\mathrm{r}=0)$, gerando fatores independentes uns dos outros (Damásio, 2012). Todavia, tal premissa raramente é atingida nas pesquisas em ciências sociais, tendo em vista a dificuldade de se tratar de forma estanque comportamentos humanos, fracionando-os em subunidades independentes umas das outras (Schmitt \& Sass, 2011).

Sendo assim, optou-se por realizar uma revisão semântica e teórica em todos os itens, tendo em vista a opção por realizar uma nova análise fatorial com rotação oblíqua, na qual é permitido que os fatores sejam correlacionados entre si (Schmitt \& Sass, 2011).

Desta forma, em um primeiro momento, todos os itens foram reescritos com base na literatura referente aos mecanismos de aprendizagem (ações de gestão de conhecimento). Após essa ação, os itens foram submetidos a três doutorandos e dois mestrandos do Programa de PósGraduação em Administração (PPGA) da Universidade de Brasília (UnB). Esta fase consistiu da análise semântica e teórica dos itens, com o objetivo de que fossem eliminados eventuais termos e palavras que dificultassem a compreensão dos itens, ou que se encontrassem fora do contexto teórico da pesquisa (Pasquali, 1997).

Posteriormente, todos os itens foram submetidos à avaliação de cinco professores do PPGA. Pasquali (1997) denomina essa fase como sendo a avaliação por juízes, ou seja, submete-se o instrumento às pessoas com habilidade e prática na construção de instrumentos psicológicos, além de serem reconhecidamente experts no construto tratado na pesquisa.

A evolução das sugestões e observações de cunho semântico e teórico realizadas permitiu a elaboração de uma nova escala, a qual foi submetida a uma pequena amostra do público-alvo, com o objetivo de verificar se eram compreensíveis para os membros da população à qual o instrumento se destina e para dirimir as eventuais dúvidas que os itens suscitavam. 
Após todo esse processo, chegou-se a uma nova escala composta de 24 itens, conforme exposto na Tabela 8 .

Tabela 8

Itens adaptados da EMAO.

\begin{tabular}{|c|c|}
\hline $\mathrm{N}^{\mathrm{o}}$ & Item \\
\hline 1 & A organização incentiva seus integrantes a participar de grupos externos e redes de pessoas. \\
\hline 2 & $\begin{array}{l}\text { A organização promove parcerias com outras organizações, tais como universidades, empresas privadas } \\
\text { e ONG. }\end{array}$ \\
\hline 3 & A organização mantém contatos com profissionais e especialistas externos. \\
\hline 4 & A organização incentiva que os indivíduos proponham novas ideias em relação aos assuntos de trabalho. \\
\hline 5 & $\begin{array}{l}\text { A organização oferece oportunidades de aprendizagem, tais como programas internos de capacitação, } \\
\text { visitas técnicas a outros departamentos. }\end{array}$ \\
\hline 6 & $\begin{array}{l}\text { A organização identifica indivíduos da própria organização com expertise em assuntos específicos, por } \\
\text { meio de catálogos ou quaisquer outras formas de registro. }\end{array}$ \\
\hline 7 & $\begin{array}{l}\text { A organização proporciona meios para que seus integrantes participem de eventos externos (ex.: } \\
\text { congressos, feiras e simpósios). }\end{array}$ \\
\hline 8 & $\begin{array}{l}\text { A organização proporciona ao público interno a consulta às bases de dados ou repositório de documentos } \\
\text { por meio de algum tipo de rede interna (ex.: intranet). }\end{array}$ \\
\hline 9 & $\begin{array}{l}\text { A organização propicia ambientes informais para que os indivíduos compartilhem conhecimentos e } \\
\text { experiências entre colegas de trabalho. }\end{array}$ \\
\hline 10 & A organização incentiva que os indivíduos compartilhem sugestões no ambiente de trabalho. \\
\hline 11 & A organização fomenta o trabalho em equipe. \\
\hline 12 & $\begin{array}{l}\text { A organização incentiva que novas ideias e abordagens sobre desempenho no trabalho sejam aplicadas } \\
\text { no dia-a-dia. }\end{array}$ \\
\hline 13 & $\begin{array}{l}\text { A organização proporciona encontros para informar aos indivíduos a respeito de inovações em suas } \\
\text { atividades. }\end{array}$ \\
\hline 14 & $\begin{array}{l}\text { A organização realiza mudanças de profissionais entre departamentos e funções, proporcionando a } \\
\text { participação do indivíduo em outras equipes. }\end{array}$ \\
\hline 15 & A organização incentiva o rodízio de tarefas entre os profissionais da organização. \\
\hline 16 & $\begin{array}{l}\text { A organização informa seus integrantes a respeito de responsabilidades de outros colegas de trabalho e } \\
\text { departamentos. }\end{array}$ \\
\hline 17 & $\begin{array}{l}\text { A organização fomenta o compartilhamento de práticas de trabalho entre seus diversos setores, por meio } \\
\text { de mecanismos formais (ex.: reuniões agendadas, espaço na rede interna para registro de procedimentos, } \\
\text { dentre outras). }\end{array}$ \\
\hline 18 & $\begin{array}{l}\text { A organização disponibiliza base de dados que proporciona a recuperação de conhecimentos sobre } \\
\text { atividades e processos desenvolvidos. }\end{array}$ \\
\hline 19 & $\begin{array}{l}\text { A organização estabelece em quais bases de dados (físicas ou virtuais) os conhecimentos específicos dos } \\
\text { indivíduos devem ser materializados. }\end{array}$ \\
\hline 20 & A organização conta com base de dados referente a outras organizações com as quais mantém interação. \\
\hline 21 & $\begin{array}{l}\text { A organização define políticas para o armazenamento de informações e conhecimentos em bases de } \\
\text { dados de algum tipo de rede interna (ex.: intranet e repositório físico de documentos). }\end{array}$ \\
\hline 22 & A organização utiliza métodos para localização de conhecimentos armazenados nas bases de dados. \\
\hline 23 & A organização utiliza métodos para a atualização das bases de dados disponíveis. \\
\hline 24 & $\begin{array}{l}\text { A organização incentiva que as lições aprendidas a partir de resultados de projetos organizacionais sejam } \\
\text { documentadas como resultado de sucessos importantes ou sobre a razão de fracassos. }\end{array}$ \\
\hline
\end{tabular}

Nota. Fonte: Elaborado pelo Autor.

Em relação à escala sobre compartilhamento de conhecimento, a revisão bibliográfica realizada apontou a existência de algumas escalas sobre o construto, todavia, optou-se pela 
elaboração de uma nova escala psicométrica, baseando-se nos motivos que serão tratados a seguir.

Huang (2009) e Xue, Bradley e Liang (2011) desenvolvem pesquisas que abordam a elaboração de instrumentos de pesquisa com o objetivo de mensurar o comportamento de compartilhamento do conhecimento. Todavia, ambos os trabalhos não detalham o método utilizado para a elaboração dos itens, dificultando a rastreabilidade do processo de elaboração da escala e a sua eventual utilização em outras pesquisas.

Ademais, a revisão bibliográfica realizada nesta pesquisa apontou diversos comportamentos que poderiam compor a estrutura subjacente ao construto compartilhamento do conhecimento, ao passo que as pesquisas de Huang (2009) e Xue, et al. (2011) apresentaram escalas que não abordaram o fenômeno em sua completude, tendo sido constituídas por 5 e 3 itens, respectivamente.

Por outro lado, a revisão realizada apontou a existência da escala desenvolvida por Yi (2009), a qual é constituída por 28 itens distribuídos por 4 fatores que explicaram 75,20\% da variância do fenômeno, quais sejam: contribuições escritas (5 itens), comunicações organizacionais ( 8 itens), interações pessoais (8 itens) e comunidades de práticas (7 itens).

Ainda que a escala de Yi (2009) tenha sido utilizada por outros estudos associados ao contexto organizacional (Aizpurúa, Saldaña \& Saldaña, 2011; Özbebek \& Toplu, 2011; Palacios-Marqués, Peris-Ortiz \& Merigó, 2013), optou-se por não utilizar a referida escala tendo em vista esta haver sido concebida somente com base nos quatro modos de compartilhamento individual identificados por Bartol e Srivastava (2002): contribuição de conhecimento para o banco de dados organizacionais, compartilhamento de conhecimento por meio de interações formais e informais e compartilhamento do conhecimento por meio de comunidades de práticas. 
Desta forma, mesmo que o trabalho de Bartol e Srivastava (2002) componha o referencial teórico desta pesquisa, julgou-se conveniente não utilizar um instrumento que houvesse sido elaborado estritamente com base em tais autores, tendo em vista que a oportunidade de elaboração de uma escala que abordassem múltiplos autores representa a oportunidade de abordar o fenômeno com uma abrangência que amplia o poder de análise sobre o compartilhamento do conhecimento sob múltiplas perspectivas.

Sendo assim, a revisão bibliográfica realizada viabilizou com que o compartilhamento do conhecimento fosse contextualizado dentro do sistema de gestão do conhecimento, para que, então, fosse possível delimitar as definições constitutivas e operacionais do fenômeno (Pasquali, 2010).

Segundo Pasquali (2010), definição constitutiva é o conceito consolidado em dicionários e teorias, tendo-se como base a constituição estabelecida em outros conceitos. Por outro lado, a definição operacional deve ser literalmente operacional, abrangendo de forma mais ampla a variável, ou seja, a variável deve ser definida em termos de operações concretas e comportamentos físicos por meio dos quais possa ser concretizada e traduzida (Pasquali, 2010).

Desta forma, ainda que a pesquisa não possua a pretensão de realizar uma minuciosa revisão conceitual, convém destacar as conceituações que amparam a condução desse trabalho, conforme Tabela 9.

\section{Tabela 9}

Definições constitutiva e operacional sobre compartilhamento do conhecimento

\begin{tabular}{|c|c|}
\hline \multirow{2}{*}{$\begin{array}{l}\text { Definição } \\
\text { Constitutiva }\end{array}$} & $\begin{array}{l}\text { Intercâmbio de conhecimento por meio de interações sociais em ambientes físicos ou virtuais, } \\
\text { ou de acesso a repositórios da organização, de forma que ocorra a compreensão do } \\
\text { conhecimento compartilhado. }\end{array}$ \\
\hline & $\begin{array}{l}\text { Autores utilizados: Nonaka e Takeuchi (1995); Nonaka e Konno (1998); Nonaka et al. (2000); } \\
\text { Szulanski (2000); Bartol e Srivastava (2002); Probst et al. (2002); Tonet e Paz (2006); Hartung } \\
\text { \& Oliveira, 2013. }\end{array}$ \\
\hline $\begin{array}{c}\text { Definição } \\
\text { Operacional }\end{array}$ & $\begin{array}{l}\text { - O indivíduo tem acesso às pessoas que possuem o conhecimento. } \\
\text { - O indivíduo compartilha o conhecimento com outras pessoas da organização, por meio de } \\
\text { atividades fomentadas pela organização. } \\
\text { - O receptor do conhecimento é capaz de explicar, esquematizar, utilizar e reproduzir o } \\
\text { conhecimento compartilhado em prol da organização. }\end{array}$ \\
\hline
\end{tabular}

Nota. Fonte: Elaborado pelo Autor. 
Posteriormente foram elaborados quinze itens sobre "compartilhamento do conhecimento", os quais passaram pelo mesmo procedimento de validação semântica e teórica descrito anteriormente para a escala de mecanismos de aprendizagem. A Tabela 10 consolida a versão final dos itens sobre compartilhamento do conhecimento.

Tabela 10

Itens sobre compartilhamento do conhecimento.

\begin{tabular}{|c|c|}
\hline $\mathrm{N}^{\mathrm{o}}$ & Assertiva \\
\hline 1 & Mantenho interação com grupos ou redes de pessoas na organização. \\
\hline 2 & $\begin{array}{l}\text { Participo de grupos ou redes de pessoas, externos à organização, que possuem afinidade com a minha } \\
\text { atividade profissional. }\end{array}$ \\
\hline 3 & Mantenho contato com especialistas da organização com conhecimento reconhecido em temas específicos. \\
\hline 4 & $\begin{array}{l}\text { Participo de programas de aprendizagem, tais como atividades internas de capacitação, cursos e visitas } \\
\text { técnicas a outras organizações. }\end{array}$ \\
\hline 5 & $\begin{array}{l}\text { Utilizo o conhecimento adquirido nas atividades internas, (ex.: ações de capacitação interna e reuniões de } \\
\text { trabalho) para a consecução de objetivos organizacionais. }\end{array}$ \\
\hline 6 & Desenvolvo minhas atividades na organização em equipe. \\
\hline 7 & $\begin{array}{l}\text { Converso com outros colegas sobre assuntos relacionados ao trabalho em encontros casuais (ex.: por } \\
\text { exemplo, intervalo do café e confraternizações da organização). }\end{array}$ \\
\hline 8 & $\begin{array}{l}\text { Utilizo o conhecimento fruto das conversas com meus colegas da organização para a resolução de } \\
\text { problemas do trabalho. }\end{array}$ \\
\hline 9 & Compartilho conhecimento relacionado com as atividades que realizo em reuniões de trabalho. \\
\hline 10 & $\begin{array}{l}\text { Utilizo ambientes virtuais (ex.: e-mail, rede intranet e teleconferência) para interação com colegas de } \\
\text { trabalho. }\end{array}$ \\
\hline 11 & Desenvolvo novas ideias e conceitos por meio de diálogos com colegas de trabalho. \\
\hline 12 & Assimilo conhecimentos por meio de observações, imitações ou práticas de colegas de trabalho. \\
\hline 13 & Durante as atividades diárias exponho o meu conhecimento por meio de analogias e exemplos. \\
\hline 14 & $\begin{array}{l}\text { Compartilho conhecimento com colegas de trabalho por meio de documentos e/ou repositórios virtuais de } \\
\text { documentos. }\end{array}$ \\
\hline 15 & Utilizo o conhecimento armazenado nas bases de dados físicas e virtuais da organização. \\
\hline
\end{tabular}

Nota. Fonte: Elaborado pelo Autor.

Após os itens relativos a mecanismos de aprendizagem e compartilhamento do conhecimento, o questionário apresenta algumas questões demográficas com o objetivo de que sejam identificadas algumas características da população pesquisada. Todavia, apenas algumas questões foram tratadas de maneira global, tendo em vista a especificidade de cada organização pesquisada, conforme será abordado na seção de resultado e análise de dados.

Por fim, a consolidação dos itens das duas escalas desenvolvidas permite que seja abordado o procedimento de coleta e de análise de dados descrito na próxima seção. 


\subsection{Procedimentos de coleta e de análise de dados}

No que diz respeito ao procedimento de coleta de dados, utilizou-se a internet como meio de comunicação para a condução de uma pesquisa on line. A realização de uma coleta de dados não presencial representa a oportunidade de se maximizar e aproveitar as potencialidades da internet por meio da utilização de ferramentas que representem a rapidez, redução de custos e possibilidade de comunicação com respondentes que se encontrem a grandes distâncias (Castells, 2004).

Desta forma, cada respondente recebeu um email que continha um texto explicativo sobre a pesquisa além de um link que direcionava o participante para o questionário que havia sido colocado na plataforma de pesquisa SurveyMonkey (instrumento em anexo).

Em relação ao método de análise de dados, inicialmente foi utilizado análise fatorial em cada uma das escalas desenvolvidas. Posteriormente foi realizada uma correlação canônica entre o grupo de variáveis independentes (fatores da escala de mecanismos de aprendizagem) e o grupo de variáveis dependentes (fatores da escala de compartilhamento de conhecimento). Ou seja, a opção pela utilização da correlação canônica se ampara na intenção da pesquisa em mensurar empiricamente a intensidade da relação e a capacidade da predição dos mecanismos de aprendizagem sobre o compartilhamento do conhecimento, objetivos estes que só poderiam ser atingidos por meio da utilização de um método que proporcionasse a operacionalização de uma regressão com múltiplas variáveis independentes e dependentes, tendo em vista a constituição dos três fatores da escala de compartilhamento de conhecimento, conforme será visto posteriormente. Em ambas as análises foi utilizado o software Statistical Package for the Social Sciences (SPSS), na versão 22.

Hair et al. (2010) pontuam que as técnicas estatísticas multivariadas são indicadas para a análise de múltiplas medidas sobre indivíduos em investigação. Desta forma, a partir deste 
ponto serão abordados os aspectos que nortearam a realização da análise fatorial e a correlação canônica dos dados coletados.

\subsection{Análise Fatorial}

Tabachnick e Fidell (2007) pontuam sobre a tendência da utilização da técnica de análise fatorial nas ciências sociais. Tal afirmação se ampara no argumento de que a análise fatorial permite encontrar a estrutura subjacente a uma matriz de dados, de forma a determinar o número e a natureza de suas variáveis latentes (fatores), os quais permitam a melhor representação do conjunto de variáveis observadas (Brown, 2006; Damásio, 2012).

Ou seja, ao se analisar a estrutura das inter-relações existentes nas variáveis mensuradas, objetivou-se observar quais variáveis partilham variância em comum, pertencendo, pois, ao mesmo fator (Hair et al., 2010; Tabachnick \& Fidell, 2007). O procedimento descrito a seguir foi utilizado de forma idêntica para a análise fatorial realizada em ambas as escalas.

Rozzett e Demo (2010) afirmam que o processo de validação de uma escala psicométrica pode ser sintetizado em uma sequência que consiste da coleta de dados, a sua limpeza e tratamento, a análise fatorial propriamente dita e a aferição da confiabilidade dos fatores por meio do índice alfa de Cronbach $(\alpha)$.

Em relação à etapa de limpeza e tratamento, procedeu-se a exploração dos dados obtidos quanto aos dados ausentes, tamanho da amostra, normalidade das distribuições, linearidade e casos extremos (Hair et al., 2010; Tabachnick \& Fidell, 2007).

No que diz respeito aos dados ausentes, verificou-se a frequência absoluta em cada variável e em cada respondente. Em função de o questionário ter sido aplicado por meio eletrônico na plataforma SurveyMonkey, todas as variáveis demonstraram possuir menos do que 
5\% de dados ausentes, não tendo sido necessária a adoção de qualquer procedimento estatístico para tratamento dos dados omissos (Hair et al., 2010; Tabachnick \& Fidell, 2007)

Em relação ao tamanho da amostra, MacCalum, Widaman, Zhang e Hong (1999) e Pasquali (2005) sugerem que em caso de incertezas quanto ao número de fatores subjacentes à estrutura do instrumento sejam necessários 10 respondentes para cada item do instrumento, ressaltando-se que a análise fatorial com menos de 200 sujeitos não deve ser considerada como adequada.

Neste aspecto, ambas as escalas cumpriram os requisitos. A escala de mecanismos de aprendizagem possui 24 itens, atingindo a marca de 268 respondentes (média de 11,1 respondente/item). Enquanto a escala de compartilhamento de conhecimento (com 15 itens) possui 251 respondentes (média de 16,7 respondentes/item).

No que tange à normalidade das distribuições foram analisadas inicialmente os índices de skewness e kurtosis das variáveis. Todas as variáveis de ambas as escalas demonstraram possuir valores de skewness e kurtosis diferentes de zero. A significância desses valores foi verificada por meio do Score Z, considerando um nível de significância de 0,05.

Posteriormente, analisaram-se os histogramas das variáveis (com curva normal), bem como foram procedidos os testes de normalidade (K-S e Shapiro-Wilk), os quais apontaram a ausência de distribuição normal em diversas variáveis, predominando de forma geral a assimetria negativa.

Amparado na argumentação de Pasquali (2005), na qual ausência de normalidade das variáveis não representa maiores problemas na análise fatorial, tendo em vista a robustez desta técnica frente às violações deste pressuposto em amostras com mais de 200 respondentes (Hair et al., 2010; Pasquali 2005), optou-se por realizar a análise fatorial sem a transformação dos dados coletados. 
Em seguida, verificou-se o pressuposto de linearidade, por meio de análise da correlação existente de forma bivariada, examinando a magnitude das correlações entre os pares de variáveis. A realização dessa análise indicou a presença de associação linear entre algumas variáveis, com intensidades variadas entre os diversos pares formados. De maneira geral, nenhuma correlação se mostrou próxima de 0,90 , sugerindo ausência de multicolinearidade (Pasquali, 2005).

Por fim, procurou-se identificar os casos extremos (em inglês, outliers), fossem eles univariados ou multivariados. Os casos univariados foram identificados por meio do exame gráfico das variáveis presentes no banco de dados.

Por outro lado, os outliers multivariados foram identificados por meio da distância de Mahalanobis. Sendo assim, realizou-se uma regressão linear "fictícia", em que a identificação do sujeito (ID) foi utilizada como variável dependente, enquanto as 24 variáveis sobre mecanismos de aprendizagem e 15 variáveis sobre compartilhamento de conhecimento foram tratadas como variáveis independentes, respectivamente.

Com base no método de Mahalanobis, verificou-se que com 24 e 15 graus de liberdade, os quais foram considerados como sendo o número de variáveis independentes para cada escala, respectivamente, e probabilidade $p<0,001$, apurou-se que 6 respondentes representavam outliers multivariados para a escala 1 (respondente $23,40,126,153,203$ e 228) e 3 casos constituíam outliers multivariados para a escala 2 (respondentes 146, 162 e 251).

Tendo em vista o potencial que os outliers multivariados possuem de impactar a matriz de correlações, pois diminuem ou ampliam a magnitude associações entre as variáveis (Hair et al., 2010; Pasquali 2005; Tabachnick \& Fidell, 2007), optou-se por excluir tais casos das análises subsequentes, tendo e vista que tal ação não prejudicaria a taxa de respondente por item. Desta forma, a amostra ajustada totalizou 262 respondentes para a de "Mecanismos de Aprendizagem" e 248 respondentes para a escala de "Compartilhamento do Conhecimento". 
Após a limpeza dos dados procedeu-se à análise fatorial de ambas as escalas. Inicialmente, empregou-se o método de análise dos componentes principais, em conjunto com a análise da fatorabilidade dos dados por meio do índice KMO - Kaiser-Meyer-Olkin, do teste de esfericidade de Bartlett e do percentual das correlações acima de 0,30 (Hair et al., 2010; Tabachnick \& Fidell, 2007).

Após a análise dos componentes extraídos, determinou-se a quantidade de fatores da escala, tendo como base a quantidade de variância explicada em cada componente, o valor de eigenvalue (ou autovalor) mínimo igual a 1,0, a interpretação do gráfico de scree plot e, principalmente, o significado teórico de cada agrupamento de itens (Hair et al., 2010; Tabachnick \& Fidell, 2007).

Para rotação dos fatores foi utilizado o método dos eixos principais com rotação oblíqua do tipo oblimin e promax, tendo em vista os fatores apresentarem correlações significativas entre eles. Optou-se pela estrutura definida com a rotação promax, utilizando-se o critério de interpretabilidade (Pasquali, 2005), conforme será detalhado na seção de análise de dados, posteriormente.

Após a rotação dos fatores alguns itens foram excluídos com base nos seguintes critérios: (a) apresentaram carga fatorial semelhante em mais de um fator (diferença menor que 0,1) (Laros \& Puente-Palácios, 2004); (b) carga fatorial inferior a 0,35 (Hair, et al., 2010); e (c) falta de conexão teórica com o fator associado. Por fim, verificou-se a confiabilidade dos fatores, por meio do cálculo do índice alfa de Cronbach, utilizando-se o próprio SPSS.

\subsection{Análise de Correlação Canônica}

Após a análise fatorial, optou-se por realizar uma análise de correlação canônica. Conforme argumentado anteriormente, a opção pela utilização da correlação canônica se deve 
em função da intenção de mensurar empiricamente a intensidade da relação e a capacidade da predição dos mecanismos de aprendizagem sobre o compartilhamento do conhecimento.

Segundo Hair et al. (2010), Hotelling (1936) foi um dos precursores na correlação canônica, consolidando tal técnica como sendo o método multivariado que permite a análise da relação entre múltiplas variáveis independentes e múltiplas variáveis dependentes, podendo ser tais variáveis métricas ou não métricas. Sendo assim, a opção pela operacionalização da correlação canônica mostrou ser a técnica de análise mais adequada, tendo em vista a constituição da escala de mecanismos de aprendizagem em três fatores, ou seja, três variáveis independentes, e a escala de compartilhamento de conhecimento em três fatores, constituindose em três variáveis dependentes, conforme será abordado futuramente na seção de análise de dados.

Desta forma, Alpert e Peterson, (1972) e Hair et al. (2010) classificam a correlação canônica como uma técnica derivada da regressão, sendo que o seu objetivo principal consiste na quantificação da intensidade da relação existente os vetores formados pelo grupo de variáveis independentes e o grupo das variáveis dependentes (Hair et al., 2010; Tabachnick \& Fidell, 2007).

Em outras palavras, Hair et al. (2010) e Tabachnick e Fidell (2007) afirmam que a correlação canônica permite identificar a melhor estrutura de cada grupo de variáveis que maximiza a relação entre as variáveis dependentes e independentes, proporcionando uma combinação linear associada a cada grupo de variáveis que potencialize a correlação entre os dois grupos de variáveis.

A correlação canônica será aplicada para proporcionar a análise das possíveis interrelações entre as variáveis independentes representadas pelos fatores a serem extraídos da análise fatorial realizada na escala de mecanismos de aprendizagem e as variáveis dependentes, 
sendo estas os fatores provenientes da análise fatorial realizada na escala sobre compartilhamento de conhecimento.

Todavia, a realização da correlação canônica é precedida do cumprimento de alguns critérios quanto ao tamanho da amostra, a ligação teórica existente entre as variáveis, os dados perdidos, casos extremos (outliers), além dos aspectos de linearidade, multicolinearidade e normalidade (Hair et al., 2010). Tendo em vista todos esses critérios já haverem sido analisados por ocasião da análise fatorial, procedeu-se à realização do teste de significância Wilks, com o objetivo de que fosse verificada a significância coletiva das funções canônicas. Posteriormente, realizou-se a correlação canônica propriamente dita.

A correlação canônica desenvolve uma função canônica, a qual maximiza o coeficiente de correlação canônica entre as duas variáveis canônicas. A primeira função canônica extraída representa o máximo da variância explicada pelo conjunto de variáveis. A segunda função computada responde pela variância não explicada pela primeira equação, e assim sucessivamente (Alpert \& Peterson, 1972; Hair et al., 2010).

Todavia, tendo em vista as variáveis dependentes demonstrarem possuir alto nível de correlação entre si (acima de 0,50) (Hair et al., 2010), optou-se por realizar uma análise univariada ANOVA no grupo de variáveis dependentes, com o objetivo de que fossem captadas as dimensões subjacentes a este grupo de variáveis, proporcionando uma análise mais precisa da mensuração realizada com base em construtos sociais e psicológicos (Lambert \& Durand, 1975; Field, 2009).

Após analisar os parâmetros das funções descritos no parágrafo anterior, foi observada a recomendação de Alpert e Peterson (1972), Dillon e Goldstein (1984) e Hair et al. (2010), os quais reafirmam a importância de que seja procedida a interpretação dos resultados das funções canônicas, segundo os seguintes critérios: (1) o coeficiente de correlação canônica $(R c)$; (2) a quantidade de variância partilhada entre os dois grupos de variáveis canônicas $\left(R c^{2}\right)$; (3) os 
coeficientes de correlação canônica padronizados (pesos canônicos); (4) a estrutura de correlação (cargas canônicas); e (5) o índice de redundância.

A análise dos resultados do coeficiente de correlação canônica mensura a força da relação entre as duas variáveis canônicas, ao passo que cada variável canônica é interpretada por meio das cargas canônicas, das correlações das variáveis individuais e das suas respectivas variáveis (Lambert \& Duran, 1975; Dillon e Goldstein, 1984; Hair et al., 2010).

O coeficiente de correlação canônica $(R c)$ representa a relação entre ambos os grupos de variáveis, mensurando a correlação existente. Quando tal índice é levado ao quadrado, esse novo valor indica a quantidade de variância compartilhada $\left(R c^{2}\right)$ entre o grupo de variáveis dependentes e independentes (Alpert \& Peterson, 1972; Lambert \& Duran, 1975; Hair et al., 2010).

Todavia, Hair et al. (2010) apontam para a diferença conceitual existente entre a quantidade de variância compartilhada entre os dois grupos de variáveis $\left(R c^{2}\right)$ e a quantidade de variância do grupo de variáveis independentes que é explicado pelo grupo de variáveis dependentes, e vice-versa.

Hair et al. (2010) afirmam que cada variável responde por apenas uma porção da variância do seu grupo de variáveis. Desta forma, ainda que dois grupos de variáveis possuam o índice $R c^{2}$, isso não quer dizer que cada variável é explicada nessa porção. Ao invés disso, o grupo de variáveis só é explicado em função do grau que esta se relaciona com a variação da função (Rc) (Stewart, Douglas, \& Love, 1968; Hair et al., 2010).

Sendo assim, para a determinação da variância explicada em determinado grupo de variáveis pelo grupo oposto (índice de redundância), levou-se em consideração não apenas o $R c^{2}$, mas também as cargas canônicas de cada variável.

No que diz respeito à estrutura de correlação, também conhecida como cargas canônicas, tal índice mensura a correlação linear entre uma variável original do grupo de 
variáveis dependentes ou independentes e o grupo de variáveis canônicas. Ou seja, a carga canônica reflete a variância que a variável observada compartilha com a variável canônica e pode ser interpretada como um fator de carga na contribuição relativa de cada variável em cada função canônica (Alpert \& Peterson, 1972; Lambert \& Duran, 1975; Hair et al., 2010).

Em relação aos pesos canônicos, examinou-se o sinal e a magnitude de cada variável associada ao respectivo grupo canônico, no qual variáveis com um peso maior contribuem de forma mais significativa do que as de peso menor (Lambert \& Duran, 1975; Hair et al., 2010).

Analogamente, variáveis cujos pesos possuem sinais negativos possuem uma relação inversa entre as demais, ao passo que as variáveis com pesos positivos possuem uma relação direta (Lambert \& Duran, 1975; Hair et al., 2010).

Todavia, a utilização dos pesos canônicos para a análise da correlação entre as variáveis é enfraquecida, tendo em vista que tal parâmetro tende a ser fortemente influenciado pela amostra de respondentes utilizada (Lambert \& Duran, 1975; Hair et al., 2010). Desta forma, ainda que esta pesquisa contemple o cálculo dos pesos canônicos, a análise sobre a pertinência das variáveis independentes e dependentes dentro de cada conjunto canônico de variáveis será analisado com base nas cargas canônicas obtidas por cada variável dentro do seu conjunto canônico, como será abordado na seção de análise de dados.

Com o objetivo de operacionalizar a análise de correlação canônica, utilizou-se de forma semelhante à Fávero (2005) a sintaxe da Figura 2, no software estatístico SPSS.

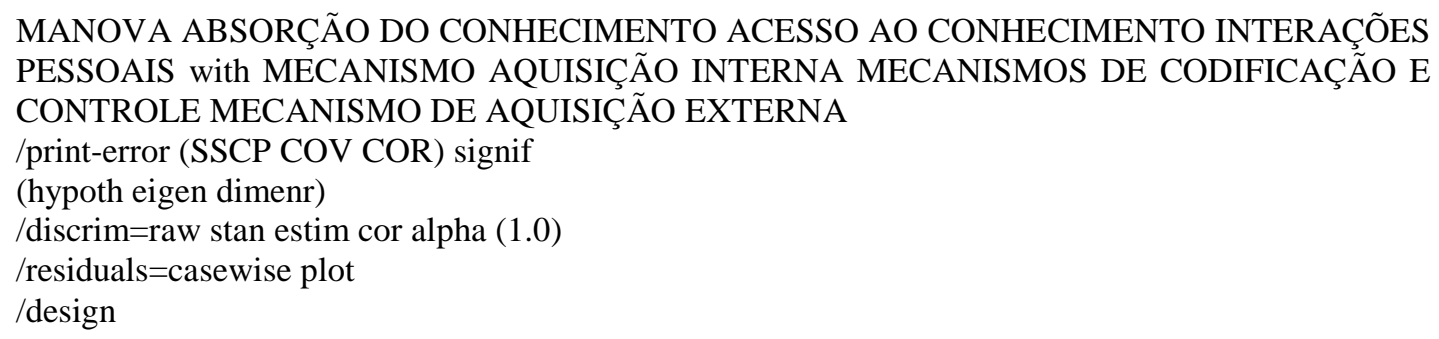

Figura 2. Sintaxe utilizada no SPSS Fonte: Dados da Pesquisa. 
Com base no processo de análise delimitado, as próximas seções descrevem e discutem os resultados encontrados. 


\section{RESULTADO E ANÁLISE DE DADOS}

Esta seção aborda a análise dos dados, bem como propõe algumas reflexões sobre os resultados alcançados. Inicialmente serão abordados os dados relacionados a alguns aspectos demográficos da população. Posteriormente, proceder-se-á às análises fatoriais realizadas nas escalas de mecanismos de aprendizagem e de compartilhamento de conhecimento. Em seguida será realizada a análise de correlação canônica entre os dois grupos de variáveis.

\subsection{Dados Demográficos}

Os dados da Tabela 11 apontam uma amostra predominantemente do sexo masculino (71,37\%), podendo este índice ter carregado a influência da grande presença de organizações militares pesquisadas. A idade dos respondentes apresentou grande concentração na faixa entre 31 e 50 anos $(64,50 \%)$, conforme Tabela 11.

Tabela 11

Dados quanto ao sexo e idade da amostra pesquisada.

\begin{tabular}{|c|c|c|c|c|c|}
\hline Sexo & $\mathrm{N}$ & $\%$ & Idade & $\mathrm{N}$ & $\%$ \\
\hline Masculino & 177 & 71,37 & De 20 a 30 anos & 45 & 18,40 \\
\hline \multirow[t]{4}{*}{ Feminino } & 71 & 28,63 & De 31 a 40 anos & 82 & 33,40 \\
\hline & & & De 41 a 50 anos & 76 & 31,10 \\
\hline & & & De 51 a 60 anos & 39 & 15,90 \\
\hline & & & Acima de 60 anos & 3 & 1,20 \\
\hline
\end{tabular}

Nota. Fonte: Dados da Pesquisa

A Tabela 12 aponta que a amostra apresentou uma grande quantidade de pessoas com, no mínimo, o nível de especialização $(62,00 \%)$, caracterizando o alto nível de escolaridade da amostra. Ainda que não tenham sido identificadas pesquisas que ratifiquem tal reflexão, presume-se que o alto nível de escolaridade da amostra possa contribuir para o compartilhamento do conhecimento, tendo em vista a possibilidade de que tais indivíduos 
possam compreender e valorizar os benefícios do compartilhamento do conhecimento para o desempenho dos próprios indivíduos e da organização como um todo (Alvarenga Neto, 2008).

Contudo, ainda que os pesquisados possuam alto nível de escolaridade, os mesmos desempenham suas respectivas funções há pouco tempo, com 76,90 \% possuindo, no máximo, 3 anos na função atual (Tabela 12).

Tabela 12

Dados quanto ao nível de escolaridade e o tempo na função.

\begin{tabular}{cccccc}
\hline Nível de Escolaridade & $\mathrm{N}$ & $\%$ & Tempo na Função Atual & $\mathrm{N}$ & $\%$ \\
\hline Técnico & 28 & 11,30 & Menos de 1 ano & 61 & 25,60 \\
Graduação & 66 & 26,70 & De 1 a 3 anos & 122 & 51,30 \\
Especialização & 110 & 44,60 & De 4 a 6 anos & 38 & 16,00 \\
Mestrado & 39 & 15,80 & De 7 a 9 anos & 5 & 2,10 \\
Doutorado & 4 & 1,60 & Com 10 ou mais anos & 12 & 5,00 \\
\hline
\end{tabular}

Nota. Fonte: Dados da Pesquisa

Em relação ao vínculo com a organização, todos os pesquisados são concursados e com plano de carreira estabelecido em suas respectivas organizações.

Martelane (1991) destaca a presença de dois grupos funcionais bem distintos nas organizações públicas: os funcionários permanentes e os funcionários não permanentes. O grupo permanente é composto por indivíduos de carreira, cujos aspectos culturais são formados no seio da organização, enquanto os sujeitos não permanentes são administradores políticos, os quais seguem objetivos externos e mais amplos aos da organização.

A característica da população de possuir apenas indivíduos do quadro permanente pode contribuir para um comportamento mais favorável à ocorrência do fenômeno, tendo em vista que a predominância de tal grupo de funcionários possa proporcionar a estabilidade e confiança necessárias para que os indivíduos compartilhem o conhecimento no ambiente de trabalho.

Conforme explicado anteriormente na seção de método, as demais questões demográficas dos questionários não foram tratadas de maneira global, tendo em vista a especificidade de cada organização. 


\subsection{Escala de Mecanismos de Aprendizagem}

A análise fatorial da escala de mecanismos de aprendizagem foi procedida por meio do estudo do agrupamento dos componentes principais. Além de $74 \%$ das correlações da matriz terem sido maiores do que 0,30 , os dados da Tabela 13 atestam a fatorabilidade da matriz de correlações, com base no resultado do teste esfericidade de Bartlett e no índice KMO de 0,934, tendo sido este último considerado como "maravilhoso" (Kaiser, 1974).

Tabela 13

Fatorabilidade da escala de Mecanismos de Aprendizagem

\begin{tabular}{ccc}
\hline \multicolumn{2}{c}{ Medida Kaiser-Meyer-Olkin de adequação de amostragem. } &, 934 \\
\cline { 2 - 3 } Teste de esfericidade de Bartlett & Aprox. Qui-quadrado & 4102,587 \\
\cline { 2 - 3 } & Df & 276 \\
\cline { 2 - 3 }
\end{tabular}

Nota. Fonte: Dados da Pesquisa

Em relação à quantidade de fatores a serem extraídos, o gráfico de scree plot (Figura 3), os valores de eingenvalue e a quantidade de variância explicada apontaram a existência de 4 fatores, conforme Tabela 14 .

Tabela 14

Síntese da análise dos componentes principais da escala de Mecanismos de Aprendizagem

\begin{tabular}{ccccc}
\hline \multirow{2}{*}{ Fator } & \multicolumn{3}{c}{ Valores próprios iniciais } & $\begin{array}{c}\text { Somas rotativas de carregamentos } \\
\text { ao quadrado }^{\mathrm{a}}\end{array}$ \\
\cline { 2 - 5 } & Autovalor & \% de variância & \% cumulativa & Total \\
\hline 1 & 10,627 & 44,280 & 44,280 & 10,627 \\
2 & 2,395 & 9,978 & 54,258 & 2,395 \\
3 & 1,558 & 6,492 & 60,750 & 1,558 \\
4 & 1,253 & 5,220 & 65,870 & 1,253 \\
\hline
\end{tabular}

Nota. Fonte: Dados da Pesquisa 


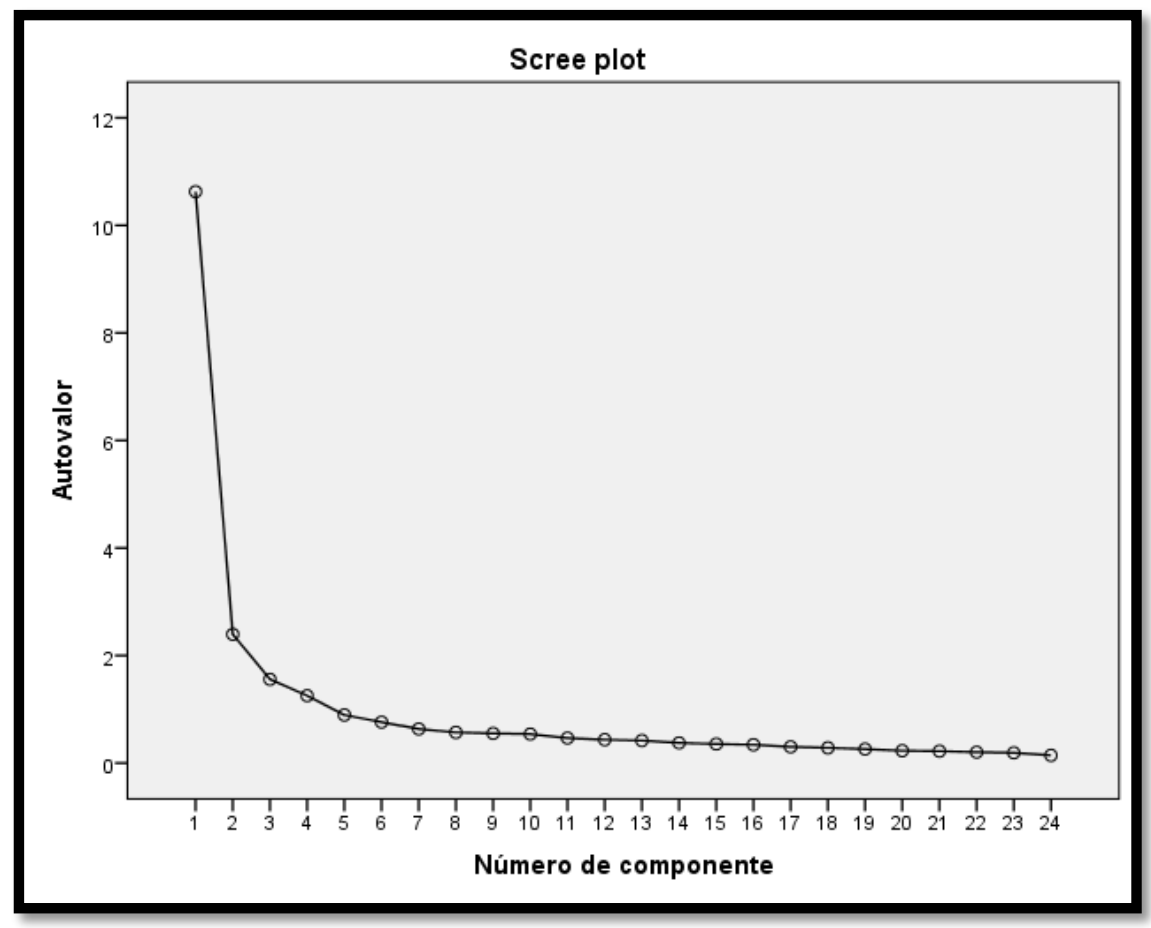

Figura 3. Gráfico scree plot da escala de Mecanismos de Aprendizagem Fonte: Dados da Pesquisa.

Todavia, a rotação com quatro fatores não proporcionou grande ajustamento entre a estrutura apresentada pela escala e o referencial teórico adotado, ratificando a premissa de que a aplicação de técnicas estatísticas se apresenta apenas como um instrumento a ser utilizado pelo pesquisador, ao passo que a relevância teórica do agrupamento continua a ser o critério determinante para a delimitação da quantidade de fatores (Pasquali, 2005).

Sendo assim, tomando como base o referencial teórico adotado e a comparação entre as estruturas fatoriais admitidas quando rotacionadas com quatro e com três fatores, optou-se pela solução com três fatores.

A análise dos fatores estabelecidos destacou que os itens 1 (“A organização incentiva seus integrantes a participar de grupos externos e redes de pessoas") e 5 (“A organização oferece oportunidades de aprendizagem, tais como programas internos de capacitação, visitas técnicas a outros departamentos") se aglutinaram nos fatores "mecanismos de aquisição interna" e “mecanismos de aquisição externa", respectivamente. Todavia, optou-se pela exclusão dos itens 
1 e 5, tendo em vista ao não alinhamento da redação do item com a definição adotada para a constituição do respectivo fator.

Em relação ao item 1, a palavra "externo" pode ter induzido o respondente ao entendimento de que o estabelecimento da rede se daria no ambiente externo da organização, quando na verdade a intenção era de que essa palavra sugerisse o estabelecimento de redes de relacionamento do indivíduo com outras pessoas ou setores da própria organização. Esta divergência semântica pode ter influenciado na baixa carga assumida pelo item dentro do fator $(0,429)$. Sugere-se que o item 1 seja replicado em pesquisas futuras, adotando uma nova redação, qual seja “A organização incentiva seus integrantes a participar de grupos e redes de pessoas na organização".

No que diz respeito ao item 5, a palavra "interno" sugere que o a realização do programa de capacitação ocorre dentro da organização, quando na verdade o objetivo era representar a realização de programas de capacitação externos à organização, porém com o suporte desta. Ou seja, a palavra "interno" causa um conflito semântico entre o mecanismo de aprendizagem retratado no item e a definição do fator "mecanismo de aquisição externa", tendo sido optado pela exclusão do item 5 .

Contudo, sugere-se que o item 5 seja reaproveitado em pesquisas futuras, com o objetivo que retrate o suporte da organização como um "mecanismo de aquisição externa", adotando-se uma nova sugestão de redação: “A organização oferece oportunidades de aprendizagem, tais como programas de capacitação e visitas técnicas a outras organizações”.

Sendo assim, após a exclusão desses dois itens, a escala de mecanismos de aprendizagem ficou consolidada com 22 itens. Após essa análise, procedeu-se a uma nova extração de fatores, com os 22 itens que remanescentes, utilizando o método dos eixos principais (PAF), com rotação promax. Após seis iterações foi obtida a melhor estrutura da escala tendo sido analisada a confiabilidade de cada fator por meio do índice alfa de Cronbach. 
De forma resumida, a escala de mecanismos de aprendizagem ficou constituída por 22 itens em sua versão final, distribuídos em três fatores, os quais explicaram uma variância total de $62,20 \%$, com somente dois itens com carga abaixo de 0,50 .

Quanto à qualidade dos itens, de acordo com Comrey e Lee (1992), um item excelente possui carga maior que 0,71 , um item muito bom possui carga maior que 0,63 , um item bom possui carga maior que 0,55 , um item razoável possui carga maior que 0,45 e um item pobre possui carga maior que 0,32 . No que diz respeito à confiabilidade dos fatores, Pasquali (2005) atesta que alphas de Cronbach $(\alpha)$ acima de 0,70 são considerados confiáveis, ao passo que os valores acima de 0,80 são muito confiáveis.

Com base em tais parâmetros e no arcabouço teórico sobre o tema, essa primeira análise fatorial permite algumas reflexões. O fator "Mecanismos de Aquisição Interna" (Tabela 15) se apresentou como responsável pela maior parte da variância explicada, destacando um forte aspecto associado à perspectiva de ações de gestão de conhecimento associadas aos aspectos de personalização do conhecimento (Joia \& Oliveira, 2007).

Tabela 15

Síntese do fator Mecanismos de Aquisição Interna

\section{Mecanismos de Aquisição Interna}

Conjunto de ações proporcionadas pela organização que favorece a interação social entre os indivíduos no ambiente de trabalho, de forma que os conhecimentos e experiências sejam compartilhados entre os membros do contexto interno organizacional.

\begin{tabular}{clccc}
\hline Item & \multicolumn{1}{c}{ Descrição } & $\begin{array}{c}\text { Carga } \\
\text { Fatorial }\end{array}$ & Qualidade & $\mathrm{H}^{2}$ \\
\hline 10 & $\begin{array}{l}\text { A organização incentiva que os indivíduos compartilhem } \\
\text { sugestões no ambiente de trabalho. }\end{array}$ & 0,907 & Excelente & 0,692 \\
\hline 11 & A organização fomenta o trabalho em equipe. & 0,824 & Excelente & 0,674 \\
\hline 4 & $\begin{array}{l}\text { A organização incentiva que os indivíduos proponham novas } \\
\text { ideias em relação aos assuntos de trabalho. }\end{array}$ & 0,814 & Excelente & 0,608 \\
\hline 12 & $\begin{array}{l}\text { A organização incentiva que novas ideias e abordagens sobre } \\
\text { desempenho no trabalho sejam aplicadas no dia-a-dia. }\end{array}$ & 0,803 & Excelente & 0,639 \\
\hline 16 & $\begin{array}{l}\text { A organização informa seus integrantes a respeito de } \\
\text { responsabilidades de outros colegas de trabalho e } \\
\text { departamentos. }\end{array}$ & 0,757 & Excelente & 0,643 \\
\hline 9 & $\begin{array}{l}\text { A organização propicia ambientes informais para que os } \\
\text { indivíduos compartilhem conhecimentos e experiências entre } \\
\text { colegas de trabalho. }\end{array}$ & 0,704 & Muito Bom & 0,502 \\
\hline 13 & $\begin{array}{l}\text { A organização proporciona encontros para informar aos } \\
\text { indivíduos a respeito de inovações em suas atividades. }\end{array}$ & 0,684 & Muito Bom & 0,544 \\
\hline 14 & $\begin{array}{l}\text { A organização realiza mudanças de profissionais entre } \\
\text { departamentos e funções, proporcionando a participação do } \\
\text { indivíduo em outras equipes. }\end{array}$ & 0,612 & Bom & 0,627 \\
\end{tabular}




\begin{tabular}{|c|c|c|c|c|}
\hline 6 & $\begin{array}{l}\text { A organização identifica indivíduos da própria organização com } \\
\text { expertise em assuntos específicos, por meio de catálogos ou } \\
\text { quaisquer outras formas de registro. }\end{array}$ & 0,566 & Bom & 0,536 \\
\hline 15 & $\begin{array}{l}\text { A organização incentiva o rodízio de tarefas entre os } \\
\text { profissionais da organização. }\end{array}$ & 0,560 & Bom & 0,679 \\
\hline 17 & $\begin{array}{l}\text { A organização fomenta o compartilhamento de práticas de } \\
\text { trabalho entre seus diversos setores, por meio de mecanismos } \\
\text { formais (ex.: reuniões agendadas, espaço na rede interna para } \\
\text { registro de procedimentos, dentre outras). }\end{array}$ & 0,461 & Regular & 0,607 \\
\hline \multicolumn{3}{|c|}{ Confiabilidade - Alpha de Cronbach } & \multicolumn{2}{|c|}{0,924} \\
\hline \multicolumn{3}{|c|}{ Autovalor } & \multicolumn{2}{|c|}{9,967} \\
\hline \multicolumn{2}{|c|}{ Variância Total } & & \multicolumn{2}{|c|}{45,305} \\
\hline
\end{tabular}

Nota. Fonte: Dados da Pesquisa

O fator "Mecanismos de Aquisição Interna" (Tabela 15) converge para os resultados encontrados por Crossan, Lane e White (1999) e Faoro e Oliveira (2014), os quais constatam a consolidação de ações no âmbito interno da organização com o objetivo de institucionalizar a interação social entre os indivíduos, proporcionando ambientes favoráveis à troca de experiências e conhecimentos.

Ainda que autores como Lipshitz e Popper (1996) e Lipshitz et al. (2002) tenham ressaltado a importância das ações de rodízio de atividades, a consolidação com altas cargas fatoriais de itens que retratam esse tipo de mecanismo ratifica a argumentação de Slater e Narver (1995), na qual as organizações voltadas ao compartilhamento de conhecimento devem ser flexíveis e capazes de realocar suas fontes de recursos humanos em novos desenhos organizacionais, com o objetivo de responder às ameaças do ambiente, ou ainda aproveitar eventuais oportunidades.

Mezias, Grinyer e Guth (2001), Tonet e Paz (2006) e Hartung e Oliveira (2013) destacam que os indivíduos dependem do compartilhamento do conhecimento para melhor tomada de decisão em prol da organização. Ou seja, a constituição do fator "Mecanismos de Aquisição Interna" representa o conjunto de ações que viabilizem a interação entre os indivíduos, por meios formais ou informais, com o objetivo de que os conhecimentos adquiridos sejam compartilhados dentro da equipe (Lim \& Klobas, 2000; Aurum et al., 2008). 
No que diz respeito aos itens associados aos fatores "Mecanismos de Aquisição e Interna" (Tabela 15) e "Mecanismos de Aquisição Externa" (Tabela 17), tais itens foram agrupados de forma semelhante à proposta de López et al. (2005), e diferente da escala adaptada por Isidro-Filho (2009), na qual os itens se aglutinaram em um único fator.

A constituição do fator "Mecanismos de Codificação e Controle" (Tabela 16) converge para os resultados encontrados por Yang e Chen (2007), em uma pesquisa sobre as características de capacidade de conhecimento organizacional de determinada organização. Yang e Chen (2007) identificam a fator - Conhecimento Técnico como sendo o responsável pela explicação de significativa parcela da variância, definindo-o como a habilidade de integrar e desenvolver conhecimento por meio da utilização eficiente de tecnologias de informação e comunicação.

Tabela 16

Síntese do fator Mecanismos de Codificação e Controle

\section{Mecanismos de Codificação e Controle}

Conjunto de ações proporcionadas pela organização que favorece o armazenamento, a localização, o acesso, a utilização e a gestão das bases de dados e das experiências dos indivíduos em prol das atividades da organização.

\begin{tabular}{|c|c|c|c|c|}
\hline Item & Descrição & $\begin{array}{l}\text { Carga } \\
\text { Fatorial }\end{array}$ & Qualidade & $\mathrm{H}^{2}$ \\
\hline 22 & $\begin{array}{l}\text { A organização utiliza métodos para localização de } \\
\text { conhecimentos armazenados nas bases de dados. }\end{array}$ & 0,968 & Excelente & 0,746 \\
\hline 23 & $\begin{array}{l}\text { A organização utiliza métodos para a atualização das bases de } \\
\text { dados disponíveis. }\end{array}$ & 0,957 & Excelente & 0,739 \\
\hline 21 & $\begin{array}{l}\text { A organização define políticas para o armazenamento de } \\
\text { informações e conhecimentos em bases de dados de algum tipo } \\
\text { de rede interna (ex.: intranet e repositório físico de } \\
\text { documentos). }\end{array}$ & 0,858 & Excelente & 0,657 \\
\hline 18 & $\begin{array}{l}\text { A organização disponibiliza base de dados que proporciona a } \\
\text { recuperação de conhecimentos sobre atividades e processos } \\
\text { desenvolvidos. }\end{array}$ & 0,723 & Excelente & 0,700 \\
\hline 19 & $\begin{array}{l}\text { A organização estabelece em quais bases de dados (físicas ou } \\
\text { virtuais) os conhecimentos específicos dos indivíduos devem } \\
\text { ser materializados. }\end{array}$ & 0,652 & Muito bom & 0,677 \\
\hline 20 & $\begin{array}{l}\text { A organização conta com base de dados referente a outras } \\
\text { organizações com as quais mantém interação. }\end{array}$ & 0,640 & Muito bom & 0,465 \\
\hline 24 & $\begin{array}{l}\text { A organização incentiva que as lições aprendidas a partir de } \\
\text { resultados de projetos organizacionais sejam documentadas } \\
\text { como resultado de sucessos importantes ou sobre a razão de } \\
\text { fracassos. }\end{array}$ & 0,533 & Razoável & 0,591 \\
\hline 8 & $\begin{array}{l}\text { A organização proporciona ao público interno a consulta às } \\
\text { bases de dados ou repositório de documentos por meio de algum } \\
\text { tipo de rede interna (ex.: intranet). }\end{array}$ & 0,457 & Razoável & 0,394 \\
\hline
\end{tabular}


Autovalor

Variância Total

10,249

Nota. Fonte: Dados da Pesquisa

A utilização de mecanismos de codificação e controle é fortemente amparada em novas tecnologias que suportam o estabelecimento de processos e ações que permitam o compartilhamento de conhecimento de forma coordenada e estruturada (Probst et al., 2002; Alvarenga Neto, 2008).

Em relação ao fator "Mecanismo de Aquisição Externa" (Tabela 17), Davenport e Prusak (1998) e Probst et al. (2002) argumentam quanto a necessidade de ações de aquisição de conhecimento no ambiente externo à organização. Porém, Dodgson (1993), Sinkula, (1994) e López et al. (2005) vão além da simples ratificação dessa necessidade.

Dodgson (1993), Sinkula, (1994) e López et al. (2005) enfatizam a importância de que as organizações interajam com o ambiente de forma proativa, resultando não só na aquisição e conhecimentos necessários às atividades organizacionais, mas, sobretudo, a compreensão de como tal conhecimento é tratado e compreendido fora dos limites da organização.

Tabela 17

Síntese do fator Mecanismos de Aquisição Externa

\section{Mecanismos de Aquisição Externa}

Conjunto de ações proporcionadas pela organização que favorece a interação dos indivíduos com sujeitos e/ou grupos de indivíduos de outras organizações, cujas atividades possuem afinidade com as atividades organização promotora da ação.

\begin{tabular}{clccc}
\hline \multicolumn{1}{c}{ Item } & \multicolumn{1}{c}{ Descrição } & $\begin{array}{c}\text { Carga } \\
\text { Fatorial }\end{array}$ & Qualidade & $\mathrm{H}^{2}$ \\
\hline 2 & $\begin{array}{l}\text { A organização promove parcerias com outras organizações, tais } \\
\text { como universidades, empresas privadas e ONG. }\end{array}$ & 0,882 & Excelente & 0,458 \\
\hline 3 & $\begin{array}{l}\text { A organização mantém contatos com profissionais e } \\
\text { especialistas externos. }\end{array}$ & 0,622 & Bom & 0,400 \\
\hline $\begin{array}{l}\text { A organização proporciona meios para que seus integrantes } \\
\text { participem de eventos externos (ex.: congressos, feiras e } \\
\text { simpósios). }\end{array}$ & 0,415 & Razoável & 0,491 \\
\hline $\begin{array}{l}\text { Confiabilidade - Alpha de Cronbach } \\
\text { Autovalor } \\
\text { Variância Total }\end{array}$ & & 0,726 \\
\hline
\end{tabular}

Nota. Fonte: Dados da Pesquisa

Por outro lado, o fator "Mecanismos de Aquisição Externa" ratifica a importância do estabelecimento do relacionamento com outros grupos de pessoas ou organizações, os quais podem proporcionar a interação com outros agentes, cujas eventuais atitudes favoráveis e 
colaborativas podem contribuir para a solução de problemas no ambiente organizacional (López et al. 2005; Isidro-Filho, 2009).

Ainda que a consistência interna do fator "Mecanismos de Aquisição Externa" tenha sido considerada boa (acima de 0,70), acrescenta-se a possibilidade de que sejam elaborados mais itens que retratem tal mecanismo, o que poderia aumentar a quantidade da variância explicada pelo Fator e, consequentemente, acarretar na melhora do instrumento como um todo (Pasquali, 2005).

Por fim, apesar desses de os itens 1 (“A organização incentiva seus integrantes a participar de grupos externos e redes de pessoas") e 5 (“A organização oferece oportunidades de aprendizagem, tais como programas internos de capacitação, visitas técnicas a outros departamentos") haverem sido excluídos neste estudo, sugere-se que os mesmos sejam utilizados em pesquisas futuras, com nova redação, com o objetivo de que se aprofunde a análise dos reais motivos de determinadas ações possuírem mais ou menos aderência em ambientes organizacionais, levando-se em consideração os aspectos culturais, de comprometimento e de tolerância ao erro que existem em cada ambiente organizacional (Lipshitz et al., 2002).

Em uma última análise, os coeficientes de correlação entre os fatores apontaram correlações consideráveis (próximas a 0,5), o que justifica a adoção do critério oblíquo para rotação dos fatores (Tabachnick \& Fidell, 2007), conforme a Tabela 18. Ressalta-se que os resultados para a pattern matrix (efeitos diretos) foram semelhantes ao da structure matrix (efeitos totais).

Tabela 18

Matriz de Correlação de Fator da Escala de Mecanismos de Aprendizagem

\begin{tabular}{cccc}
\hline Fator & 1 & 2 & 3 \\
\hline 1 & 1,000 &, 631 &, 462 \\
2 &, 631 & 1,000 &, 312 \\
3 &, 462 &, 312 & 1,000 \\
\hline
\end{tabular}

Nota. Fonte: Dados da Pesquisa 
A análise fatorial da escala de mecanismos de aprendizagem e a delimitação dos três fatores estabelecidos viabilizam o aprofundamento e mensuração de aspectos teóricos vivos em discussões como a relação entre o compartilhamento do conhecimento e as ações proporcionadas pela organização (Nonaka \& von Krogh, 2009), a análise dos aspectos organizacionais que podem influenciar na criação e manutenção dos contextos propícios ao compartilhamento do conhecimento (Tsoukas, 2009) e a interação dos indivíduos dentro de um contexto capacitante proporcionado pela organização, considerando-se os seus componentes ativos e latentes (Argote \& Miron-Spektor, 2011).

De maneira global, a consolidação da estrutura fatorial admitida pela escala de mecanismos de aprendizagem possibilita a mensuração de um conjunto de ações organizacionais que podem exercer influência direta na criação de oportunidades para que os indivíduos aprendam uns com os outros, reduzindo as distâncias físicas e sociais dentro da organização, além de proporcionar condições e orientações técnicas para que tal compartilhamento realmente ocorra (Nadler et al., 2003; Borgatti \& Cross, 2003; Moresi \& Mendes, 2010).

\subsection{Escala de Compartilhamento do Conhecimento}

A análise fatorial da escala de compartilhamento de conhecimento seguiu os mesmos critérios e parâmetros adotados na análise da escala sobre mecanismos de aprendizagem.

A fatorabilidade da escala foi confirmada, tendo em vista os resultados do teste de esfericidade de Bartlett, além de o índice KMO de 0,902 ter sido considerado com “maravilhoso" (Kaiser, 1974), conforme Tabela 19. 
Fatorabilidade da escala de Compartilhamento de Conhecimento

\begin{tabular}{|c|c|c|}
\hline \multicolumn{2}{|c|}{ Medida Kaiser-Meyer-Olkin de adequação de amostragem. } & ,902 \\
\hline \multirow{3}{*}{ Teste de esfericidade de Bartlett } & Aprox. Qui-quadrado & 1845,728 \\
\hline & df & 105 \\
\hline & Sig. & 0,000 \\
\hline
\end{tabular}

Nota. Fonte: Dados da Pesquisa

Em relação à quantidade de fatores extraídos, a primeira análise de componentes principais apontou, por meio do gráfico de scree plot (Figura 4) e dos valores de eingenvalue dos componentes $1(6,936), 2(1,203)$ e $3(0,997)$, a existência de apenas dois fatores.

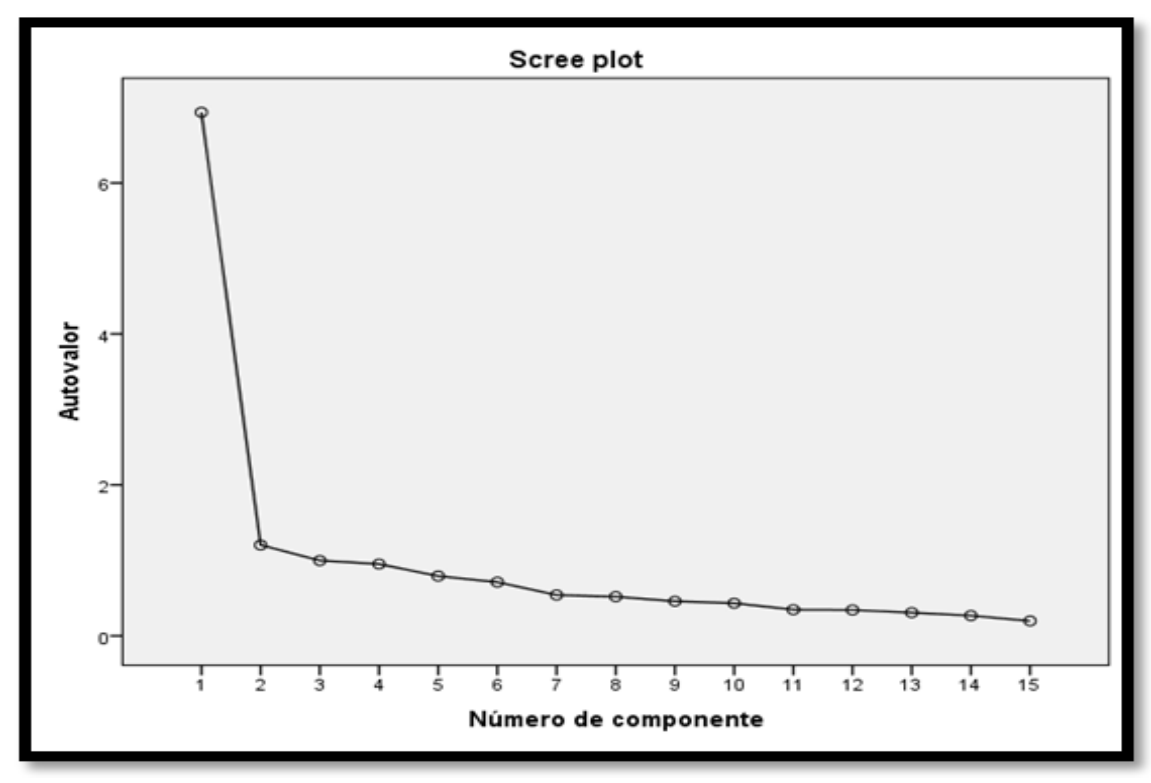

Figura 4. Gráfico scree plot da escala de Compartilhamento de Conhecimento. Fonte: Dado da Pesquisa.

Todavia, a aplicação de técnicas estatísticas se apresenta apenas como um instrumento a ser utilizado pelo pesquisador, ao passo que a relevância teórica dos fatores continua a ser o critério determinante para a delimitação da quantidade de fatores (Pasquali, 2005).

Sendo assim, tomando como base o referencial teórico adotado, o autovalor muito próximo a 1 do terceiro componente, e a quantidade de variância explicada ser maior que 3\% do terceiro componente (Hair et al., 2010) e a comparação entre as estruturas fatoriais admitidas quando rotacionadas com dois e com três fatores, optou-se pela solução com três fatores, conforme Tabela 20. 
Tabela 20

Síntese da análise dos componentes principais da escala de Compartilhamento de Conhecimento

\begin{tabular}{ccccc}
\hline \multirow{2}{*}{ Fator } & \multicolumn{3}{c}{ Valores próprios iniciais } & $\begin{array}{c}\text { Somas rotativas de carregamentos } \\
\text { ao quadrado }^{\text {a }}\end{array}$ \\
\cline { 2 - 5 } & Autovalor & \% de variância & \% cumulativa & Total \\
\hline 1 & 6,583 & 47,022 & 47,022 & 5,634 \\
2 & 1,193 & 8,519 & 55,542 & 4,747 \\
3 &, 984 & 7,029 & 62,571 & 4,037 \\
\hline
\end{tabular}

Nota. Fonte: Dados da Pesquisa

Após isso, realizou-se a rotação promax com três fatores. A análise dos fatores estabelecidos ressaltou o item 10 como "híbrido" entre os fatores 1 e 2 (diferença de carga fatorial de 0,018 ). Sendo assim, optou-se pela exclusão desse item. Após esse procedimento foi realizada uma nova rotação promax com os 14 itens restantes e delimitada em três fatores.

Após seis iterações a nova solução fatorial encontrada apontou os itens 4 e 14 como não possuidores de cargas acima de 0,35 . Essa nova estrutura fatorial se mostrou mais adequada e aderente à teoria adotada, tendo sido analisada a confiabilidade de cada fator por meio do índice alfa de Cronbach. O agrupamento dos itens permite a interpretação da estrutura com base nos seguintes fatores (1) absorção do conhecimento, (2) acesso ao conhecimento e (3) interações pessoais.

De forma global, a escala de compartilhamento de conhecimento ficou consolidada por 12 itens distribuídos por três fatores, os quais explicaram uma variância total de 62,58\% e com nenhum item tendo apresentado carga fatorial abaixo de 0,50, tendo apresentado índices satisfatórios e convergentes com o arcabouço teórico adotado. Contudo, fazem-se oportunas algumas considerações sobre os índices estatísticos e a estrutura concebida.

Em relação ao fator "Absorção do Conhecimento" (Tabela 21), percebe-se a consolidação de itens com cargas fatoriais consideradas excelentes, os quais ratificam o fato de que o compartilhamento do conhecimento é concretizado na medida em que o sujeito receptor consegue receber, compreender, absorver e reutilizar, ou melhor, recriar o conhecimento 
recebido (Hendriks, 1999; Szulanski, 2000; Huber, 2001; Ipe, 2003; Tonet \& Paz, 2006; Faoro \& Oliveira, 2014).

O agrupamento dos itens do fator "Absorção do Conhecimento" (Tabela 21) converge para a perspectiva de que o conhecimento organizacional é fruto das trocas dos saberes existentes entre os indivíduos no ambiente de trabalho (Nahapiet \& Ghoshal, 1998; Bartol \& Srivastava, 2002), sendo que o fenômeno do compartilhamento do conhecimento ocorre quando o indivíduo repassa o que sabe às pessoas com quem trabalha, ao mesmo tempo em que recebe o conhecimento que elas possuem, de forma que o destinatário ou receptor assimile o conhecimento compartilhado pela fonte ou emissor (Tonet \& Paz, 2006; Yi, 2009).

Tabela 21

Síntese do fator Absorção do Conhecimento

\begin{tabular}{clcc}
\hline \multicolumn{1}{c}{ Absorção do Conhecimento } \\
O conhecimento compartilhado por um indivíduo pode ser explicado, esquematizado e reutilizado pelo receptor \\
em prol das suas atividades na organização.
\end{tabular}

Nota. Fonte: Dados da Pesquisa

O fator "Acesso ao Conhecimento" (Tabela 22) ratifica a importância das atividades formais para o compartilhamento do conhecimento proporcionadas pela organização (Bartol \& Srivastava, 2002; Yi, 2009; Cardoso \& Gomes, 2011). A ocorrência do compartilhamento do conhecimento de maneira intencional e consciente, por meio de ações pensadas, tais como a participação de atividades em equipes constituídas pela organização (Nonaka \& Konno, 1998), 
a possibilidade de consulta à base de dados física e virtual (Joia \& Oliveira, 2007), além da participação em reuniões e atividades de treinamento e capacitação (Faoro \& Oliveira, 2014), são ratificadas por meio dos itens do fator “Acesso ao Conhecimento" (Tabela 22).

Tabela 22

Síntese do fator Acesso ao Conhecimento

\section{Acesso ao Conhecimento}

O indivíduo compartilha o conhecimento com outras pessoas da organização, por meio de atividades formais fomentadas pela organização.

\begin{tabular}{clccc}
\hline \multicolumn{1}{c}{ Item } & \multicolumn{1}{c}{ Descrição } & $\begin{array}{c}\text { Carga } \\
\text { Fatorial }\end{array}$ & Qualidade & $\mathrm{H}^{2}$ \\
\hline 6 & Desenvolvo minhas atividades na organização em equipe. & 0,785 & Excelente & 0,548 \\
\hline 15 & $\begin{array}{l}\text { Utilizo o conhecimento armazenado nas bases de dados físicas } \\
\text { e virtuais da organização. }\end{array}$ & 0,614 & Bom & 0,371 \\
\hline $\begin{array}{l}\text { Utilizo o conhecimento adquirido nas atividades internas, (ex.: } \\
\text { ações de capacitação interna e reuniões de trabalho) para a } \\
\text { consecução de objetivos organizacionais. }\end{array}$ & 0,570 & \multirow{2}{*}{ Bom } & 0,570 \\
\hline $\begin{array}{l}\text { Confiabilidade - Alpha de Cronbach } \\
\text { Autovalor } \\
\text { Variância Total }\end{array}$ & & 0,724 \\
\hline
\end{tabular}

Nota. Fonte: Dados da Pesquisa

A Tabela 23 resume o fator "Interações Pessoais". Os três itens desse fator vão ao encontro da premissa básica para a ocorrência do fenômeno: para que haja compartilhamento o indivíduo tem que ter a oportunidade de interagir com a fonte emissora do conhecimento (Cross et al., 1999; Hendriks, 1999; Coff et al., 2006; Tonet \& Paz, 2006; Yi, 2009).

Tabela 23

Síntese do fator Interações Pessoais

\section{Interações Pessoais}

O indivíduo tem acesso ao conhecimento por meio de interações com pessoas e/ou grupos de indivíduos com conhecimentos afins com a sua atividade profissional.

\begin{tabular}{clccc}
\hline \multicolumn{1}{c}{ Item } & \multicolumn{1}{c}{ Descrição } & $\begin{array}{c}\text { Carga } \\
\text { Fatorial }\end{array}$ & Qualidade & $\mathrm{H}^{2}$ \\
\hline 2 & $\begin{array}{l}\text { Participo de grupos ou redes de pessoas, externos à organização, } \\
\text { que possuem afinidade com a minha atividade profissional. }\end{array}$ & 0,769 & Excelente & 0,440 \\
\hline $1 \quad \begin{array}{l}\text { Mantenho interação com grupos ou redes de pessoas na } \\
\text { organização. }\end{array}$ & 0,634 & Muito Bom & 0,426 \\
\hline $\begin{array}{l}\text { Mantenho contato com especialistas da organização com } \\
\text { conhecimento reconhecido em temas específicos. }\end{array}$ & 0,528 & Regular & 0,527 \\
\hline $\begin{array}{l}\text { Confiabilidade - Alpha de Cronbach } \\
\text { Autovalor }\end{array}$ & & 0,753 \\
Variância Total
\end{tabular}

Nota. Fonte: Dados da Pesquisa

De forma similar, os fatores "Acesso ao Conhecimento" (Tabela 22) e "Interações Pessoais" (Tabela 23) apresentaram itens com cargas fatoriais muito boas. No entanto, ainda 
que a rotação com três fatores tenha sido adotada com base no critério de interpretabilidade (Pasquali, 2005), tendo em vista esta haver apresentado o agrupamento mais condizente com a teoria, considera-se razoável que algumas ações possam ser tomadas para melhorar a confiabilidade da escala.

Segundo Pasquali (2005), além da melhoria na própria redação do item, levando-se em consideração os aspectos semânticos e teóricos, considera-se a hipótese de que a variável latente (fator) possa ser representada por mais variáveis indicadoras, ou seja, o aumento da quantidade de itens poderia proporcionar o aumento da confiabilidade interna do fator.

A eliminação do item 1 (“A organização incentiva seus integrantes a participar de grupos externos e redes de pessoas da escala de mecanismo de aprendizagem”) da escala de mecanismos de aprendizagem prejudicou a análise geral dos dados, tendo em vista que a carga obtida neste fator poderia ser contrastada com a alta carga obtida no item 2 ("Participo de grupos ou redes de pessoas, externos à organização, que possuem afinidade com a minha atividade profissional") da escala de compartilhamento do conhecimento. Este fato ratifica a importância de que este item seja contemplado em pesquisas futuras.

Uma eventual carga baixa encontrada no item 1 da escala de mecanismo de aprendizagem, associada a uma alta carga do item 2 da escala de compartilhamento de conhecimento poderia sugerir alguns questionamentos sobre os reais motivos que levam os indivíduos a estabelecerem as redes de colaboração com pessoas do ambiente externo à organização, remontando à Lipshitz et al. (2002), os quais afirmam que o compartilhamento do conhecimento não depende apenas do estabelecimento dos mecanismos de aprendizagem, mas está relacionado também com as condições, culturais, psicológicas e afetivas, as quais os indivíduos estiverem inseridos.

De forma semelhante ao caso anterior, a aderência do item 3 ("Mantenho contato com especialistas da organização com conhecimento reconhecido em temas específicos”) ratifica a 
boa carga encontrada no item 6 (“A organização identifica indivíduos da própria organização com expertise em assuntos específicos, por meio de catálogos ou quaisquer outras formas de registro") da escala de mecanismos de aprendizagem. Ou seja, o indivíduo reconhece uma condição proporcionada pela organização para a identificação dos experts no ambiente organizacional, ao passo que age de forma convergente ao suporte proporcionado pela organização, mantendo uma rede de relacionamento em função da afinidade do trabalho que é realizado por ambos.

Em relação a este último caso, o alinhamento entre a condição proporcionada pela organização (na visão dos indivíduos) e a ação dos sujeitos pode estar associada às características das organizações pesquisadas. Pires e Macêdo (2006) pontuam que as organizações públicas são ambientes nos quais predominam a supervalorização da hierarquia e o apego às regras e rotinas, o que pode sugerir o acatamento de ações e rotinas emanadas da alta administração.

Pires e Macêdo (2006) ressaltam que paternalismo e o apego ao poder presentes nas organizações públicas proporcionam a centralização das decisões e a criação de barreiras para os processos de inovação e mudança. Todavia, tais características não influenciaram negativamente na adoção de ações que proporcionassem a identificação de outros experts nos assuntos da organização, sejam eles alguma outra organização, ou ainda um sujeito no ambiente organizacional de nível hierárquico inferior.

Em ambas as situações o protagonismo conferido ao outro ator poderia enfraquecer a organização perante o grupo de organizações na qual esteja inserida, ou ainda relegar para segundo plano um membro com alto cargo no ambiente organizacional, tornando-se, pois, indesejável a sua adoção (Carbone, 2000). Contudo, conforme abordado acima, esta tendência não se concretizou, demonstrando uma tendência da amostra pesquisada em adotar um comportamento favorável ao compartilhamento do conhecimento. 
Ainda com o olhar nos fatores "Acesso ao Conhecimento" (Tabela 22) e "Interações Pessoais" (Tabela 23), a constituição de ambos os agrupamentos remonta ao conceito de contexto capacitante de Nonaka e Konno (1998). Ao afirmarem a importância do contexto social no qual o conhecimento é criado e compartilhado, Nonaka e Konno (1998) reafirmam a constituição da organização como um conjunto de ambientes e grupos, os quais devem se tornar propícios para interação dos indivíduos, podendo estes ambientes serem físicos (escritórios, reuniões de negócios) ou virtuais (e-mail, rede intranet e teleconferência) (Szulanski, 2000; Bartol \& Srivastava, 2002; Yi, 2009).

Em relação aos itens 4 ("Participo de programas de aprendizagem, tais como atividades internas de capacitação, cursos e visitas técnicas a outras organizações") e 14 ("Compartilho conhecimento com colegas de trabalho por meio de documentos e/ou repositórios virtuais de documentos"), ambos os itens foram descartados em função de não haverem apresentado carga fatorial, acima de 0,35 (Hair et al., 2010).

A baixa carga fatorial do item 4 ("Participo de programas de aprendizagem, tais como atividades internas de capacitação, cursos e visitas técnicas a outras organizações”), o qual é destacado na literatura como uma ação formal de compartilhamento (Aurum et al., 2008), deveria ser contrastada com a carga obtida no item 5 ("A organização oferece oportunidades de aprendizagem, tais como programas internos de capacitação, visitas técnicas a outros departamentos") da escala de mecanismo de aprendizagem, o qual foi eliminado, conforme abordado na seção anterior.

Uma eventual carga alta ou baixa no item 5 da escala de mecanismo de aprendizagem proporcionaria com que se analisasse o fato de a organização oferecer, ou não, oportunidades de capacitação, contrastando-se com a falta de interesse de os indivíduos em participar dos programas, conforme atestado com a baixa carga do item 4 da escala de compartilhamento do conhecimento. Tais análises aliadas à característica de formação elevada e da grande demanda 
de trabalho dos pesquisados viabilizariam questionamentos quanto à adequação dos programas de capacitação às necessidades dos indivíduos no ambiente organizacional, proporcionando análise quanto ao eventual desalinhamento entre o suporte proporcionado pela organização e o comportamento dos indivíduos.

Da mesma forma, a não aderência do item 14 (“Compartilho conhecimento com colegas de trabalho por meio de documentos e/ou repositórios virtuais de documentos") se apresenta de forma antagônica às altas cargas encontradas nos seguintes itens do fator "Mecanismo de Codificação e Controle", da escala de mecanismos de aprendizagem: (a) item 22 - "A organização utiliza métodos para localização de conhecimentos armazenados nas bases de dados”; (b) item 21 - “A organização define políticas para o armazenamento de informações e conhecimentos em bases de dados de algum tipo de rede interna (ex.: intranet e repositório físico de documentos)"; (c) item 18 - "A organização disponibiliza base de dados que proporciona a recuperação de conhecimentos sobre atividades e processos desenvolvidos"; (d) item 19 - "A organização estabelece em quais bases de dados (físicas ou virtuais) os conhecimentos específicos dos indivíduos devem ser materializados"; (e) item 8 - "A organização proporciona ao público interno a consulta às bases de dados ou repositório de documentos por meio de algum tipo de rede interna (ex.: intranet)". Mais uma vez tais contradições podem estar associadas às particularidades e especificidades das organizações públicas.

Ainda que não tenham sido encontrados resultados que corroborem com essa análise, sugere-se que tal aspecto possa estar associado ao fato de que, na maioria das vezes, as organizações públicas oferecem serviços únicos, não sendo conhecidos outros fornecedores para a sociedade, sentindo-se, desta forma, menos pressionadas a prestar o serviço de maneira mais eficiente (Shepherd \& Valencia, 1996; Schall, 1997; Pires \& Macêdo, 2006). 
Dentro deste contexto, mesmo com o aumento da fiscalização e da exigência da sociedade por uma prestação de serviço eficiente e de qualidade (Batista, 2012), os funcionários de tais organizações podem apresentar certa tendência ao paternalismo e à acomodação funcional, situações estas típicas da falta de pressão do "mercado" e da certeza do "lugar cativo" no ambiente organizacional (Shepherd \& Valencia, 1996; Schall, 1997; Pires \& Macêdo, 2006).

Por conseguinte, a não aderência dos itens 4 ("Participo de programas de aprendizagem, tais como atividades internas de capacitação, cursos e visitas técnicas a outras organizações”) e 14 ("Compartilho conhecimento com colegas de trabalho por meio de documentos e/ou repositórios virtuais de documentos") representam um aspecto negativo para o compartilhamento do conhecimento no âmbito da amostra de organizações pesquisadas. Partindo-se da premissa de que o compartilhamento do conhecimento pode incrementar o desempenho organizacional (Hendriks, 1999; Argote \& Ingram, 2000; Souto, 2013), a percepção de que não se compartilha o conhecimento por meio de ações consolidadas na literatura representa a oportunidade para alavancar questionamentos sobre o porquê de em alguns ambientes administrativos tais comportamentos não serem recorrentes entres os indivíduos.

Contudo, sugere-se que os itens 4 ("Participo de programas de aprendizagem, tais como atividades internas de capacitação, cursos e visitas técnicas a outras organizações”) e 14 ("Compartilho conhecimento com colegas de trabalho por meio de documentos e/ou repositórios virtuais de documentos") sejam utilizados em eventuais investigações futuras, com o objetivo de que sejam delimitadas com mais precisão as possíveis razões que impedem ou restringem a adoção de determinado comportamento que seja mais favorável ao compartilhamento do conhecimento. 
Por fim, os coeficientes de correlação entre os fatores apontaram correlações superiores a 0,5, amparando mais uma vez a rotação oblíqua dos fatores (Tabachnick \& Fidell, 2007), conforme a Tabela 24.

Tabela 24

Matriz de correlação de fator da escala de Compartilhamento de Conhecimento

\begin{tabular}{cccc}
\hline Fator & 1 & 2 & 3 \\
\hline 1 & 1,000 &, 732 &, 633 \\
2 &, 732 & 1,000 &, 621 \\
3 &, 633 &, 621 & 1,000 \\
\hline
\end{tabular}

Nota. Fonte: Dados da Pesquisa

A estrutura fatorial da escala de compartilhamento de conhecimento confirma a concepção teórica de que o conhecimento, na perspectiva de um ativo organizacional, é algo extremamente difícil de ser compartilhado (Hendriks, 1999; Tonet \& Paz, 2006). Além disso, o compartilhamento é um fenômeno diretamente ligado ao processo de comunicação que é estabelecido entre o emissor e o receptor, podendo ocorrer de forma consciente ou inconsciente, além de envolver a capacidade do receptor de perceber e interpretar as expressões, atos, discursos e nos documentos emitidos pelo emissor (Hendriks, 1999; Szulanski, 2000; Tonet \& Paz, 2006).

De posse dos resultados da análise fatorial nas escalas de mecanismos de aprendizagem e de compartilhamento do conhecimento, pode-se afirmar que a estrutura estabelecida se mostra válida sob a perspectiva empírica, podendo ser aplicada em outros contextos organizacionais, observando-se, com base nos objetivos dos estudos e/ou características do contexto ou amostra, as recomendações anteriores de inclusão e/ou melhoria de itens.

A consolidação da estrutura fatorial permite o estabelecimento do modelo hipotético a ser testado por meio da correlação canônica a ser realizada na próxima seção, conforme a Figura 5. 


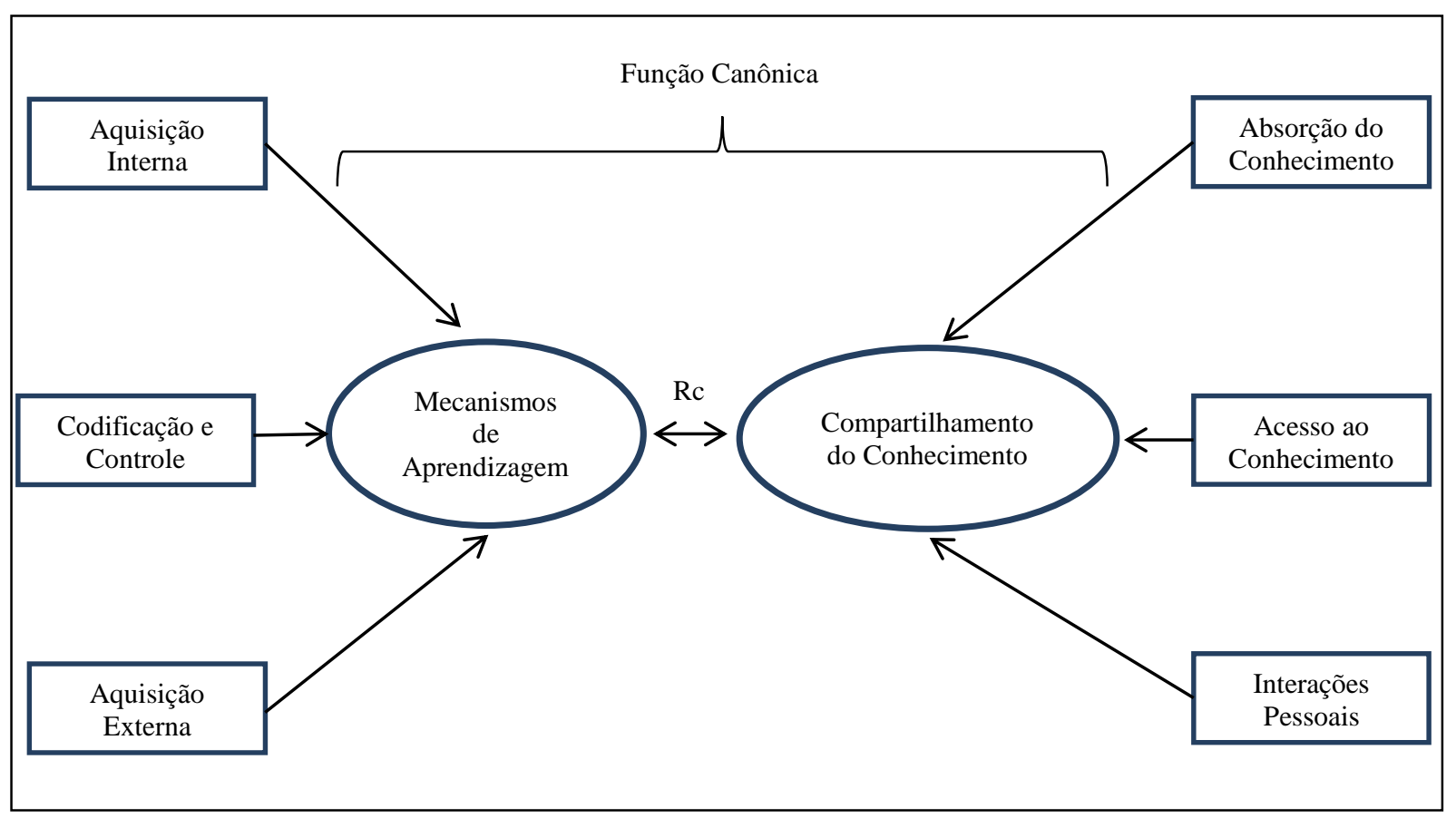

Figura 5. Esquema de correlação canônica entre as variáveis "mecanismos de aprendizagem" e "compartilhamento de conhecimento".

Fonte: Elaborado pelo autor.

\subsection{Analise de Correlação Canônica}

A análise da correlação canônica tem seu início com a realização do teste de significância multivariada. Os dados da Tabela 25 atestam a significância coletiva do conjunto de funções canônicas geradas.

Tabela 25

Teste multivariado de significância para as funções canônicas

\begin{tabular}{ccccc}
\hline Teste & Valor & Aprox. F & Erro DF & Sig. F \\
\hline Pillais & 0,07877 & 2,06727 & 690,00 &, 030 \\
Hotellings & 0,08512 & 2,14369 & 680,00 &, 024 \\
Wilks & 0,92140 & 2,10960 & 555,04 &, 027 \\
Roys & 0,7655 & & & \\
\hline
\end{tabular}

Nota. Fonte: Dados da Pesquisa

A Tabela 26 apresenta as raízes canônicas de cada função, ao mesmo tempo em que se verifica a relevância de cada uma delas. Tendo em vista que as raízes canônicas são os quadrados de cada uma das correlações canônicas (Hair et al., 2010), as equações apresentaram resultados de 0,077, 0,002 e 0,0004, atestando a baixa significância de cada uma das correlações. 
Tabela 26

Correlações canônicas e autovalores das funções canônicas

\begin{tabular}{cccc}
\hline Raiz & Autovalor & Correlação Canônica & Correlação Quadrado \\
\hline 1 & 0,08289 & 0,277 & 0,077 \\
2 & 0,00177 & 0,042 & 0,002 \\
3 & 0,00045 & 0,021 & 0,0004 \\
\hline
\end{tabular}

Nota. Fonte: Dados da Pesquisa

Ainda com base nos dados da Tabela 26, percebe-se que a primeira função canônica é gerada de modo a se obter a correlação máxima entre os dois grupos de variáveis (Lambert \& Durand, 1975; Tabachnick \& Fidell, 2007; Hair et al., 2010;). Os pares sucessivos de variáveis estatísticas canônicas são baseados na variância residual existente, com características ortogonais e independentes das outras variáveis existentes (Tabachnick \& Fidell, 2007). Ou seja, a primeira função canônica representa a máxima variância no conjunto das variáveis (Alpert \& Peterson, 1972; Hair et al., 2010).

Porém, Field (2009) ressalta a importância de que esse tipo de correlação multivariada seja seguido de uma análise univariada ANOVA no grupo de variáveis dependentes, com o objetivo de que a função canônica a ser estabelecida seja mais bem representada, tendo em vista a ocorrência de alta correlação entre as variáveis dependentes, conforme diagnosticado anteriormente.

A realização da análise univariada ANOVA ratificou a significância estatística multivariada da análise (Tabela 27), porém apontou a constituição de apenas uma função canônica para o relacionamento entre as variáveis (Tabela 28).

Tabela 27

Teste multivariado de significância para as funções canônicas

\begin{tabular}{ccccc}
\hline Teste & Valor & Exact. F & Erro DF & Sig. F \\
\hline Pillais & 0,54476 & 90,94480 & 228,00 &, 000 \\
Hotellings & 1,19664 & 90,94480 & 228,00 &, 000 \\
Wilks & 0,45524 & 90,94480 & 228,00 &, 000 \\
Roys & 0,54476 & & &
\end{tabular}

Nota. Fonte: Dados da Pesquisa

Tabela 28

Correlações canônicas e autovalores da função canônica

\begin{tabular}{cccc}
\hline Raiz & Autovalor & Correlação Canônica & Correlação Quadrado \\
\hline 1 & 1,19664 & 0,738 & 0,545 \\
\hline
\end{tabular}

Nota. Fonte: Dados da Pesquisa 
Ao confrontar os índices de correlação canônica das Tabelas $26(0,277)$ e $28(0,738)$, percebe-se que a realização da análise univariada ANOVA é essencial para que se efetue uma análise precisa quando se possui um grupo de variáveis dependentes com alto grau de correlação entre si (Lambert \& Durand, 1975; Field, 2009).

Sendo assim, com base na função canônica delimitada na Tabela 28 a força da associação entre o grupo de variáveis dependentes e independentes $(R \mathrm{c})$ é razoável $(0,738)$, ao passo que a variância compartilhada $\left(R \mathrm{c}^{2}\right)$ entre o grupo de variáveis mecanismos de aprendizagem (variável independente) e compartilhamento do conhecimento (variável dependente) é de 0,545 .

A magnitude da correlação encontrada entre o grupo de variáveis independentes (mecanismos de aprendizagem) e dependentes (compartilhamento e conhecimento) converge para os resultados da pesquisa de Yang e Chen (2007), em que os autores apontam para a correlação existente entre a capacidade de integrar normas e políticas em um contexto favorável ao compartilhamento do conhecimento $(\beta=0.190, t=2.974, \mathrm{p}<0.01)$, e a habilidade de integrar e compartilhar conhecimento por meio da utilização de tecnologias de informação e comunicação, a qual os autores denominam de capacidade técnica $(\beta=0.250, t=5.080, p<0.001)$.

Ainda que as denominações para ações de gestão de conhecimento sejam encontradas de forma diferente, a presente pesquisa e o trabalho de Yang e Chen (2007) reafirmam a força da correlação existente entre os mecanismos de aprendizagem e o compartilhamento do conhecimento organizacional.

No que diz respeito às variáveis dependentes, os coeficientes padronizados são representados pelos pesos canônicos da primeira função canônica, de forma semelhante aos coeficientes padronizados obtidos em uma análise de regressão.

Após a realização da análise univariada ANOVA, os pesos canônicos das variáveis dependentes são apresentados na Tabela 29. Percebe-se que a hierarquia dos pesos para a 
primeira função consiste na seguinte sequência: absorção do conhecimento, acesso ao conhecimento e interações pessoais. Tais resultados sugerem o peso maior do compartilhamento de conhecimento entre indivíduos por meio de ações de absorção do conhecimento, em relação a outras formas de compartilhamento.

Tabela 29

Pesos canônicos padronizados das variáveis dependentes para a primeira função canônica

\begin{tabular}{cc}
\hline Variável & Função 1 \\
\hline Absorção do Conhecimento & $-0,860$ \\
Acesso ao Conhecimento & $-0,143$ \\
Interações Pessoais & $-0,070$ \\
\hline
\end{tabular}

Nota. Fonte: Dados da Pesquisa

Em relação às variáveis independentes, a Tabela 30 apresenta os respectivos pesos das variáveis para a primeira função canônica. Percebe-se que a sequência hierárquica de influência das variáveis se constitui como mecanismos de codificação e controle, mecanismos de aquisição externa e mecanismos de aquisição interna.

Tabela 30

Pesos canônicos padronizados das variáveis independentes para a primeira função canônica

\begin{tabular}{cc}
\hline Variável & Função 1 \\
\hline Mecanismos de Aquisição Interna & $-0,108$ \\
Mecanismos de Codificação e Controle & $-0,634$ \\
Mecanismos de Aquisição Externa & $-0,415$ \\
\hline
\end{tabular}

Nota. Fonte: Dados da Pesquisa

Em relação aos pesos canônicos descritos nas Tabelas 29 e 30, Hair et al. (2010) pontuam que variáveis com pesos maiores contribuem mais para o grupo de variáveis, podendo maximizar as correlações canônicas.

Todos os pesos canônicos das Tabelas 29 e 30 apresentaram o sinal negativo, indicando uma relação inversa entre cada variável e o grupo de variáveis canônicas ao qual pertença. Por exemplo: um eventual aumento na capacidade de absorção do conhecimento implicaria em uma diminuição no compartilhamento do conhecimento. 
A análise desses dados contraria os preceitos teóricos tratados nesta pesquisa, e ao mesmo tempo ratificam as ponderações de Alpert e Peterson (1972), Lambert e Durand (1975) e Hair et al. (2010), nas quais são abordadas as dificuldade de se amparar a análise em apenas tais índices, tendo em vista a sua característica de instabilidade de uma amostra para outra, sendo necessário que sejam analisadas as correlações canônicas de cada variável dentro do seu grupo de variáveis, como será feito a seguir.

A Tabela 31 apresenta as correlações entre as variáveis dependentes e o grupo de variáveis canônicas "Compartilhamento do Conhecimento", tornando-se possível mensurar a variância compartilhada por tais variáveis na primeira função canônica, por meio da seguinte operação: $\left[(-0,990)^{2}+(-0,719)^{2}+(-0,662)^{2}\right] / 3=0,645$.

Tabela 31

Correlações entre variáveis dependentes e o grupo de variáveis canônicas "Compartilhamento do Conhecimento - Primeira Função

\begin{tabular}{cc}
\hline Variável & Função 1 \\
\hline Absorção do Conhecimento & $-0,990$ \\
Acesso ao Conhecimento & $-0,719$ \\
Interações Pessoais & $-0,662$ \\
\hline
\end{tabular}

Nota. Fonte: Dados da Pesquisa

Os dados da Tabela 31 são corroborados pelos resultados da pesquisa de van Wijk et al. (2008), na qual foi suportada uma correlação entre a capacidade de absorção do conhecimento e o compartilhamento do conhecimento $(r c=0.19, \mathrm{p}<0.001)$. Conforme exposto na Tabela 32, constata-se uma alta correlação entre as variáveis dependentes e o próprio grupo de variáveis, destacando-se a variável Absorção e Reprodução do Conhecimento. Tais resultados sugerem que todas as variáveis são boas para o grupo de variáveis dependentes delimitado, respondendo por $64,50 \%$ da variância explicada do grupo de variáveis dependentes.

De forma análoga, a Tabela 32 mostra as correlações entre as variáveis independentes e as variáveis canônicas, na primeira função canônica. A operação seguinte explicita a variância compartilhada das variáveis independentes na primeira função canônica: $\left[(-0,789)^{2}+(-\right.$ $\left.0,918)^{2}+(-0,803)^{2}\right] / 3=0,703$. 
Tabela 32

Correlações entre variáveis independentes e o grupo de variáveis canônicas "Mecanismos de Aprendizagem" - Primeira Função

\begin{tabular}{cc}
\hline Variável & Função 1 \\
\hline Mecanismos de Aquisição Interna & $-0,789$ \\
Mecanismos de Codificação e Controle & $-0,918$ \\
Mecanismos de Aquisição Externa & $-0,803$
\end{tabular}

Nota. Fonte: Dados da Pesquisa

Em relação às correlações encontradas para as variáveis independentes, percebe-se que todas as variáveis se apresentaram como boas independentes, tendo em vista as altas correlações encontradas para a primeira função canônica, as quais explicaram 70,30\% da variância compartilhada naquele grupo canônico.

Ainda em relação à alta correlação diagnosticada na Tabela 32, as conclusões encontradas por van Wijk et al. (2008) convergem para os resultados dessa pesquisa ao apontarem uma correlação significativa entre o compartilhamento do conhecimento e a proximidade da relação entre os indivíduos $(r c=0.29, \mathrm{p}<0.001)$ e os aspectos cognitivos, no que diz respeito à visão compartilhada e sistemas comuns $(r c=0.21, \mathrm{p}<0.01)$. Ou seja, a visão compartilhada de sistemas sugerida por van Wijk, et al. (2008) ratifica a importância do estabelecimento de forma precisa dos diversos mecanismos de aprendizagem listados na Tabela 32, ao passo que a proximidade da relação entre os indivíduos é ratificada por meio da alta correlação encontrada nas variáveis Mecanismos de Aquisição Interna e Mecanismos de Aquisição Externa (Tabela 33).

De forma resumida, as correlações expostas nas Tabelas 31 e 32 representam a mensuração da correlação linear simples entre uma variável observada original no conjunto dependente ou independente e a variável estatística canônica do conjunto, podendo ser analisada como uma carga fatorial na avaliação da contribuição relativa de cada variável observada em cada função canônica (Alpert \& Peterson, 1972; Lambert \& Durand, 1975; Tabachnick e Fidell, 2007; Hair et al., 2010). 
Sendo assim, ao confrontarmos os dados relativos aos pesos canônicos (Tabelas 29 e 30) e das correlações entre as variáveis (Tabelas 31 e 32), constata-se que nem todas as variáveis possuíram um peso canônico alto, porém, todas as variáveis demonstraram possuir alta correlação com o seu respectivo grupo canônico, demonstrando serem boas variáveis para explicar os construtos assumidos na pesquisa (Hair et al., 2010).

Finalmente, relaciona-se a variância compartilhada entre ambos os grupos de variáveis canônicas $\left(R \mathrm{c}^{2}\right)$ com a proporção da variância explicada pelo próprio conjunto canônico (variância compartilhada). Com esta operação se obtém o índice de redundância, o qual consiste da proporção da variância de cada conjunto que é explicado pelo conjunto canônico oposto, conforme Tabela 33 (Stewart, Douglas, \& Love, 1968; Hair et al., 2010).

Gouvêa (2004) afirma a importância de que as forças das correlações canônicas sejam superiores a 0,30 quando da estimação e seleção das funções canônicas. Os dados da Tabela 31 e 32 atestam que as intensidades de todas as correlações ficaram superiores a 0,30, ratificando a possibilidade de que sejam calculados os índices de redundância para ambos os grupos de variáveis, conforme a Tabela 33.

Tabela 33

Cálculo do índice de redundância

\begin{tabular}{cccc}
\hline $\begin{array}{c}\text { Conjunto de } \\
\text { Variáveis }\end{array}$ & $\begin{array}{c}\text { Média da Variância } \\
\text { Compartilhada }\end{array}$ & Corr. Quadrado $\left(R c^{2}\right)$ & Índice de Redundância \\
\hline Dependentes & 0,645 & 0,545 & 0,352 \\
Independentes & 0,703 & 0,383 \\
\hline
\end{tabular}

Nota. Fonte: Dados da Pesquisa

Tabachnick e Fidell (2007) e Hair et al. (2010) ponderam que o índice de redundância pode ser considerado como uma estimativa de $R^{2}$, o qual seria resultante de uma regressão, caso tivesse sido feita a opção pela regressão de forma isolada de cada variável dependente em função de todas as variáveis independentes, sendo, pois, uma estimativa da média de cada $R^{2}$ encontrado. 
Conforme dados da Tabela 33, destaca-se que o cálculo do índice de redundância é realizado tanto para as variáveis estatísticas dependentes como para as independentes, ainda que exista uma maior preocupação com a variância extraída do conjunto de variáveis dependentes, as quais fornecem uma medida preditiva mais precisa das relações canônicas. (Stewart, Douglas, \& Love, 1968; Alpert \& Peterson, 1972; Lambert \& Durand, 1975; Hair et al., 2009).

Os dados encontrados na correlação canônica destacam que as variáveis independentes (mecanismos de aprendizagem) compõem um grupo significativo no modelo de correlação canônica adotado, explicando de modo adequado uma proporção da variância do grupo de variáveis dependentes $\left(R^{2}=0,352\right)$, sendo portanto, relacionadas ao grupo de variáveis dependentes (compartilhamento do conhecimento), devendo serem contempladas em eventuais práticas de gestão de conhecimento nas organizações pesquisadas.

Este resultado converge para as reflexões de Tseng (2010) e Hamel (2009), na medida em que o estabelecimento de processos e mecanismos de aprendizagem, cujos objetivos são maximizar a eficiência da interação dos indivíduos, não são capazes de predizer o fenômeno em sua totalidade, restando $64,80 \%$ da variância do construto "compartilhamento do conhecimento" a ser explicada por outras variáveis do ambiente organizacional (Lipshitz et al., 2002).

Em uma análise final, a quantidade da variância explicada $\left(R^{2}=0,352\right)$ pelo grupo de variáveis preditoras estabelecido (mecanismos de aprendizagem) ajuda a elucidar e tornar mais palpável as discussões e afirmações trazidas por autores como Senge (1993), Zellmer-Bruhn (2003) e Terra (2001), os quais ratificam a importância da influência da ação da alta administração da organização no compartilhamento do conhecimento entre os indivíduos.

Ainda que levado em consideração o contexto e características da amostra pesquisada, a mensuração da magnitude da correlação $(R c=0,738)$ entre mecanismos de aprendizagem e 
compartilhamento de conhecimento, bem como a força preditora da variável independente sobre a dependente $\left(R^{2}=0,352\right)$, aprofunda e detalha a influência e o poder que as condições proporcionadas pela alta administração possuem em influenciar a capacidade individual de compartilhamento do conhecimento, bem como na própria intensidade do fenômeno.

A análise realizada nesta pesquisa proporciona enxergar o fenômeno sob outra lente metodológica, além das já utilizadas em estudos anteriores (Szulanski, 2000; Lipshitz et al., 2002; Tonet \& Paz, 2006; Xavier et al., 2012; Hartung \& Oliveira, 2013; Faoro \& Oliveira, 2014), evidenciando que a discussão em torno da importância dos mecanismos de gestão de conhecimento utilizados pela alta administração possui a sua importância e influência para a ocorrência do fenômeno, sendo que a compreensão das nuances que envolvem o processo de compartilhamento do conhecimento perpassa pela identificação e reconhecimento da importância de diversas outras possíveis variáveis, tais como os aspectos culturais da organização, a estrutura organizacional admitida, o afeto entre os indivíduos, o comprometimento das pessoas com as causas da organização, dentre outras (Lipshitz et al., 2002; López et al., 2005).

Por fim, a análise da relação canônica entre os grupos de variáveis independentes e dependentes serve para analisar a intensidade da correlação e do efeito preditor entre os construtos "Mecanismos de Aprendizagem" e "Compartilhamento do Conhecimento", ao passo que a análise fatorial tem o objetivo de simplificar os dados, com identificação e explicação das variáveis latentes subjacentes a um grupo de variáveis (Tabachnick \& Fidell, 2007, Hair et al., 2010). A conciliação de ambas as técnicas permite a realização de algumas reflexões e conclusões, como será visto a seguir. 


\section{CONCLUSÃO}

Sob uma perspectiva claramente cognitiva, a pesquisa admitiu a premissa de que os indivíduos interpretam e compreendem a realidade organizacional de acordo com as particularidades do seu sistema cognitivo (Antonello \& Godoy, 2011), podendo este processo ser fomentado pela utilização de mecanismos de aprendizagem que, em outras palavras, constituem-se nas ações de gestão de conhecimentos essenciais para o desempenho individual e organizacional.

O desenvolvimento da pesquisa proporcionou a continuação do trabalho realizado por Isidro-Filho (2009), tendo em vista a adaptação da escala de "Mecanismo de Aprendizagem" ter proporcionado o aperfeiçoamento de seus aspectos semânticos, teóricos e, consequentemente, dos seus parâmetros estatísticos.

Adicionalmente, a revisão bibliográfica realizada proporcionou o estabelecimento das definições constitutivas e operacionais do construto "Compartilhamento do Conhecimento", viabilizando o desenvolvimento de uma escala com validade interna consistente, a qual poderá ser aplicada em outros contextos organizacionais, conforme mencionado anteriormente.

Tendo em vista o processo de adaptação e desenvolvimento de escalas realizado, os resultados alcançados permitiram a delimitação da estrutura subjacente ao construto "Mecanismos de Aprendizagem" em três fatores, quais sejam, "Mecanismos de Aquisição Interna", "Mecanismos de Codificação e Controle" e "Mecanismos de Aquisição Externa". Em relação ao construto "Compartilhamento do Conhecimento", consolidaram-se três fatores, os quais foram denominados de "Absorção do Conhecimento", "Acesso ao Conhecimento" e “Interações Pessoais".

Em uma segunda fase da análise dos dados da pesquisa, mensurou-se a intensidade da relação entre o grupo de variáveis "Mecanismos de Aprendizagem" e "Compartilhamento do 
Conhecimento", culminado com o cálculo da capacidade preditiva do grupo de variáveis independentes sobre o grupo de variáveis dependentes. Desta forma, pode-se afirmar que os objetivos específicos da pesquisa também foram alcançados.

Após a análise dos dados, conclui-se que o objetivo de identificar empiricamente a relação existente entre os mecanismos de aprendizagem proporcionados pela organização para o compartilhamento do conhecimento e o próprio compartilhamento do conhecimento no ambiente organizacional foi cumprido, proporcionando o preenchimento de uma lacuna que havia sido identificada na revisão bibliográfica realizada.

As discussões e a análise de dados realizada nesta investigação permitem que sejam vislumbradas significativas contribuições desse trabalho para a análise e o refinamento teórico do estudo das variáveis tratadas.

No que diz respeito às ações de gestão de conhecimento, os autores trazidos no referencial teórico proporcionaram a conciliação de tais ações com o construto "Mecanismos de Aprendizagem", tendo em vista que ambos convergem para o mesmo objetivo quando analisados no ambiente organizacional.

Adicionalmente, o trabalho realizado na escala de "Mecanismo de Aprendizagem" proporciona a consolidação de um instrumento com bons parâmetros estatísticos, além de responder por uma boa quantidade da variância do construto (62,20\%). Ademais, ressalta-se que a adaptação da referida escala permitiu a continuidade de trabalhos realizados anteriormente (López et al., 2005; Isidro-Filho, 2009), ratificando a ebulição do tema no contexto dos Estudos Organizacionais.

Em relação à escala de "Compartilhamento do Conhecimento", ressalta-se que todo o método utilizado para a sua elaboração confere a fidedignidade e a validade necessárias ao referido instrumento. Consequentemente, os resultados alcançados por esta escala permitem 
que trabalhos futuros aperfeiçoem os seus itens, viabilizando a melhora de seus índices, além de proporcionar a sua utilização em outros ambientes organizacionais.

Destaca-se ainda que a condução da pesquisa ocorreu no ambiente da administração pública, todavia, o trabalho realizado em ambas as escalas não foi pensado especificamente para as organizações públicas. Ou seja, a construção semântica e teórica dos itens foi realizada com base na literatura pertinente, a qual engloba organizações dos diversos setores da economia, não restringindo a aplicação dos instrumentos apenas ao ambiente de organizações públicas.

Desta forma, ressalta-se a possibilidade de que ambas as escalas possam ser aplicadas em diferentes organizações, em diferentes setores da administração, cabendo aos futuros autores o julgamento quanto às eventuais adaptações.

Um segundo achado diz respeito à possibilidade de mensurar a relação entre as ações da alta administração, tão propaladas por Lipshitz e Popper (1996), Terra (2001), Lipshitz et al. (2002), Heizig (2009), Isidro-Filho (2009) e Amayah (2013), e o compartilhamento do conhecimento. Ação esta que não foi encontrada na amostra de produções científicas investigadas neste trabalho.

Posteriormente, vislumbrou-se a possibilidade de que fosse analisado o efeito preditivo do grupo de variáveis independentes sobre o grupo de variáveis dependentes, por meio da análise de correlação canônica, qual seja uma técnica de análise multivariada ainda pouco utilizada no contexto das pesquisas de Administração relacionadas às variáveis tratadas nesta pesquisa, proporcionando enxergar o fenômeno por outra perspectiva metodológica.

A reflexão sobre os resultados alcançados por esta pesquisa suscita a possibilidade de que sejam feitas algumas recomendações práticas para o ambiente organizacional, além de serem destacadas as limitações identificadas, bem como uma possibilidade de agenda futura de pesquisa. 


\subsection{Recomendações}

Existem muitas variáveis do comportamento humano que compõem o mosaico organizacional. Guardadas as especificidades da pesquisa e da amostra, os resultados empíricos confirmaram a alta correlação entre as variáveis "Mecanismos de Aprendizagem" e “Compartilhamento do Conhecimento", além de certo poder de predição $(35,20 \%)$ da primeira sobre a segunda. Este resultado faz emergir algumas recomendações práticas em termos de ações a serem tomadas no ambiente organizacional.

Em termos gerais, os achados dessa pesquisa permitirão que as organizações pesquisadas incrementem as ações de gestão de conhecimento constituídas nos quatro fatores da escala de mecanismos de aprendizagem, além de repensar a constituição dessas mesmas ações. Por exemplo, a alta administração pode divulgar de forma mais efetiva a utilização dos mecanismos de codificação e controle e de aquisição externa, tendo em vista a sua alta correlação com o construto mecanismo de aprendizagem, potencializando o alcance e efeito de tais ações.

Em relação ao compartilhamento do conhecimento, percebeu-se a alta correlação dos aspectos de absorção e reprodução de conhecimento com o fenômeno do compartilhamento do conhecimento, de maneira que se vislumbra a possibilidade de que as organizações pensem em maneiras que proporcionem ao indivíduo a oportunidade de reconhecer, assimilar e aplicar o novo conhecimento adquirido de fontes internas e externas (Lane, Koka \& Pathak, 2006; Zahra \& George, 2002).

No que diz respeito a outras organizações com atividades, estruturas e desenhos diferentes das que foram pesquisadas, recomenda-se analisar os resultados aqui obtidos com certa cautela. A análise conduzida inferiu que os mecanismos de aprendizagem podem predizer em certo grau o compartilhamento de conhecimento entre os indivíduos; sendo assim, 
recomenda-se que os mecanismos de aprendizagem sejam pensados e desenvolvidos por quaisquer organizações, todavia, ressalta-se a importância que os aspectos que envolvem o compartilhamento do conhecimento devam ser contextualizados em função do tipo de vínculo dos indivíduos com a organização, dos aspectos culturais envolvidos, da estrutura organizacional, além de quaisquer outros traços que distingam determinada organização ou grupo de organizações a serem pesquisadas.

Do ponto de vista das possibilidades acadêmicas, espera-se que as reflexões em relação às limitações desta pesquisa e a agenda para trabalhos futuros cumpram esse papel. A intenção é que essa investigação contribua para a aproximação e o aprofundamento da análise entre dois aspectos muito trabalhados na academia e no ambiente coorporativo: o conhecimento e a ação gerencial. As reflexões a seguir indicam que essa discussão está muito longe do fim.

\subsection{Limitações}

A principal limitação encontrada nesta pesquisa diz respeito à composição da amostra. Ainda que se tenha buscado a diversidade no ambiente da Administração Direta Federal, uma maior participação dos servidores militares pode ter influenciado em determinado grau a inferência dos resultados obtidos.

Caso tivesse sido possível uma maior participação de servidores civis oriundos dos ministérios, obter-se-iam resultados mais generalizáveis, abrangendo indivíduos de diferentes níveis hierárquicos, ao invés da concentração nos cargos de Analista Técnico de Políticas Sociais (ATPS).

Outra limitação encontrada diz respeito à ausência de respostas em relação aos aspectos demográficos da amostra. Tendo em vista o aspecto facultativo da resposta de tais questões, a caracterização da amostra ficou limitada aos aspectos tratados na seção de análise de dados, 
não sendo possível lidar com outras questões que incrementariam o poder de análise, tais como o tempo na função atual e no setor em que o respondente trabalha na organização.

A revisão bibliográfica realizada apontou uma concentração maciça de pesquisas qualitativas ou quantitativas que utilizaram estatística descritiva em sua maioria. Ou seja, com exceção feita aos estudos trazidos nessa pesquisa, constatou-se a escassez de estudos brasileiros sobre o desenvolvimento de escalas acerca dos construtos pesquisados, além da pouca utilização de métodos estatísticos multivariados no campo de estudo da variável, sendo que estes, por não apresentavam detalhes relativos ao método utilizado, trazem uma contribuição limitada ao desenvolvimento de conhecimento relativo ao tema.

Todavia, essa limitação se transformou na importante possibilidade de desenvolvimento de uma escala psicométrica sobre compartilhamento do conhecimento, além do refinamento de um instrumento que já havia sido desenvolvido sobre mecanismos de aprendizagem, tendo sido alcançados em ambas as escalas índices de confiabilidade satisfatórios que comprovam a qualidade dos instrumentos, atestando o potencial para que possam ser utilizados em pesquisas em outras organizações.

\subsection{Agenda de Pesquisa}

Os resultados obtidos por esta dissertação permitiram o cumprimento dos objetivos traçados, além de ter proporcionado contribuições importantes para reflexões sobre o comportamento das variáveis.

Existe possibilidade para que os estudos afetos ao tema sejam ampliados em complexidade, proporcionando o refinamento teórico sobre o fenômeno por meio de pesquisas empíricas que viabilizem o questionamento das teorias em sua completude. 
Ou seja, com o objetivo de complementar as análises provenientes do grande número de pesquisas qualitativas identificadas, vislumbra-se a possibilidade de que análises amparadas em métodos quantitativos mais complexos possam incrementar a compreensão do relacionamento do compartilhamento do conhecimento com outras variáveis do ambiente organizacional.

No que diz respeito à precisão teórica proporcionada pela pesquisa, sugere-se que os pesquisadores ousem dramatizar o contexto social da pesquisa, sem que, contudo, este mesmo cenário ganhe contornos sentimentais excessivos. Esta proposição se torna oportuna, pois os próprios resultados da pesquisa indicam certa capacidade de predição dos mecanismos de aprendizagem sobre o compartilhamento do conhecimento $\left(R^{2}=0,352\right)$, mas persiste a pergunta: que outras variáveis influenciam o fenômeno de compartilhar conhecimento?

Com base neste questionamento, sugere-se uma grande possibilidade de pesquisas para além da maneira cognitiva como o fenômeno foi tratado nesta própria pesquisa. Algumas situações que envolvem a motivação individual para o compartilhamento do conhecimento ainda precisam ser mais bem esclarecidas, tais como: (a) é possível que determinada pessoa compartilhe conhecimento apenas com o objetivo de que seja reconhecida como um especialista no assunto; (b) talvez alguns sujeitos compartilhem conhecimento por uma questão de altruísmo, ou seja, pelo simples prazer em ajudar o próximo; (c) por outro lado, existe a possibilidade de um sujeito ajudar outra pessoa esperando algo em troca, talvez um eventual auxílio em uma situação futura; (d) em outro viés, os indivíduos podem compartilhar o conhecimento por causa do sistema de recompensas proporcionado pela política de gestão de pessoas da organização; (e) ou simplesmente as pessoas compartilham o conhecimento por que está preconizado pela organização, tal como uma norma a seguir.

Além dessas possíveis perguntas, pode-se questionar os possíveis motivos que levem os indivíduos ao estabelecimento das suas redes de colaboração no ambiente de trabalho: (a) existe 
a possibilidade de que o indivíduo tenha interesse apenas em identificar os experts no contexto organizacional; (b) por outro lado, o estabelecimento da interação social pode estar relacionado a uma eventual disputa futura, na qual será decisivo estabelecer contato com os detentores do conhecimento, afinal de contas "conhecimento é poder"; (c) a associação a outros indivíduos pode estar ligado a algum sentimento de insegurança, e a proximidade dos detentores do conhecimento pode fazer a diferença pela sobrevivência no ambiente organizacional; e (d) a inserção de indivíduos recém-chegados na organização pode influenciar em alguma medida o compartilhamento do conhecimento entre os sujeitos, tendo em vista a possibilidade de que estes se apresentem mais motivados e dispostos a adotar um comportamento colaborativo ou, ao contrário, se comportem de forma mais tímida influenciando negativamente na ocorrência do fenômeno.

Estas e possíveis outras questões continuam a suscitar reflexões sobre o fenômeno do compartilhamento do conhecimento. Ainda que a análise desta pesquisa não possua a pretensão de generalização, infere-se que além da existência da influência da alta administração por meio de ações que proporcionem a ocorrência do fenômeno, existe a necessidade de que sejam investigadas as próprias razões dos indivíduos que os impulsionam (ou não) ao compartilhamento do conhecimento.

De forma convergente, é importante resgatar as considerações de autores como Edwards e Barry (2010), que ao pontuarem a respeito da necessidade de se dispensar especial atenção ao refinamento e precisão dos métodos de pesquisa empregados, enfatizam que as abordagens metodológicas admitidas devem proporcionar maior precisão às pesquisas em Administração. Ou seja, tem-se que o retrato da pesquisa sobre a compartilhamento do conhecimento é baseado no autorrelato, tendo em vista a supremacia da utilização de entrevistas individuais e questionários, destacando que a principal deficiência apontada na condução de tais pesquisas se deve ao forte componente do viés associado ao ponto de vista do participante da pesquisa. 
Sugere-se que sejam vislumbradas outras possibilidades de pesquisas que contemplem a análise de variáveis do comportamento organizacional associado ao processo de compartilhamento do conhecimento em vários níveis, ensejando outra frente de pesquisas que trate o fenômeno do compartilhamento conhecimento de forma multinível e em diferentes lapsos temporais, proporcionando uma maior problematização e análise do fenômeno observado.

Em outras palavras, existe uma grande possibilidade para a realização de estudos que proporcionem a análise da relação do compartilhamento do conhecimento com outras variáveis, tais como as características do próprio conhecimento, a capacidade de absorção do conhecimento pelos indivíduos, as lideranças situacionais no ambiente de trabalho, as redes de relacionamento constituídas, hierarquia, afeto, comprometimento, ou ainda, a utilização destas variáveis como moderadoras da própria relação entre os mecanismos de aprendizagem e o compartilhamento do conhecimento.

Estas possibilidades no trato da variável representam uma forma de ampliar o escopo de evidências e a validade das proposições sobre a relação do compartilhamento do conhecimento com outras variáveis do ambiente organizacional, ao mesmo tempo em que produziria novas considerações que poderiam influenciar na compreensão e consolidação teórica do campo.

Ainda como tentativa de expandir a análise a respeito do tema, é de extrema importância que seja dada igual oportunidade para que todos os integrantes da organização expressem sua visão a respeito da criação do conhecimento organizacional. Estudos concentrados em amostras que englobam apenas diretores, gerentes e gestores, captam o ponto de vista das pessoas que, na maioria das vezes, são os responsáveis pela implantação das ações de gestão, não representando o complexo ambiente composto por outros atores, tais como funcionários, estagiários e eventuais colaboradores. 


\subsection{Considerações Finais}

Por fim, ressalta-se o fato de a presente pesquisa possuir como mensagem latente a importância e a necessidade de que sejam descortinadas as nuances que envolvem o compartilhamento do conhecimento no contexto organizacional. A capacidade de predição do compartilhamento do conhecimento em função dos mecanismos de aprendizagem existe.

Porém, com base nos resultados alcançados, e respeitando todas as limitações já abordadas, existem $64,80 \%$ da variância do compartilhamento do conhecimento que ainda necessita ser testada e explicada por meio de múltiplas abordagens metodológicas em outros contextos organizacionais.

Por fim, independente da perspectiva e da inclinação que a discussão assuma, a esperança é que a discussão teórica proporcionada por essa dissertação contribua para o avanço na compreensão do processo de compartilhamento do conhecimento organizacional para além do tecnicismo e do caráter prescritivo, extrapolando o contexto entre muros da organização, contribuindo para os interesses mais amplos da sociedade. 


\section{REFERÊNCIAS}

Aizpurúa, L. I., Saldaña, P. E. Z., \& Saldaña, A. Z. (2011). Learning for sharing: An empirical analysis of organizational learning and knowledge sharing. International Entrepreneurship and Management Journal, 7, 509-518.

Alavi, M. \& Leidner, D. E. (2001). Review: Knowledge Management and Knowledge Management Systems: Conceptual Foundations and Research Issues. MIS Quarterly, 25(1), 107-136.

Alpert, M. I. \& Peterson, R. A. (1972). On the Interpretation of Canonical Analysis. Journal of Marketing Research, 9(2), 187-192.

Alvarenga Neto, R. C. D. (2008). Gestão de Conhecimento em organizações: proposta de mapeamento conceitual integrativo. São Paulo: Saraiva.

Alves, A. \& Barbosa, R. R. (2010). Influências e barreiras ao compartilhamento da informação: uma perspectiva teórica. Ciência da Informação, 39(2), 115-128.

Amayah, A. T. (2013). Determinants of knowledge sharing in a public sector organization. Journal of Knowledge Management, 17(3), 454-471.

Andrade, M. M. (2002). Como preparer trabalhos para cursos de pós-graduação: noções práticas (5a ed.). São Paulo: Atlas.

Andrade, M. T. T., Ferreira, C. V., \& Pereira, H. B. B. (2010). Uma Ontologia para a Gestão do Conhecimento no Processo de Desenvolvimento de Produto. Gestão \& Produção, 17(3), 537-551.

Andreeva, T. \& Ikhilchik, I. (2011). Applicability of the SECI Model of Knowledge Creation in Russian Cultural Context: Theoretical Analysis. Knowledge and Process Management, 18(1), 56-66.

Angeloni, M. T. \& Grotto, D. (2009). A influência da cultura organizacional no compartilhamento do conhecimento. FACES Revista de Administração, 8(2), 76-93. 
Antonello, C. S. \& Godoy, A. S. (2011). Aprendizagem Organizacional no Brasil. Porto Alegre: Bookman.

Ardichvili, A. (2008). Learning and knowledge sharing in virtual communities of practice: motivators, barriers, and enablers. Advances in Developing Human Resources, 10(4), 541-554. Argote, L. \& Ingram, P. (2000). Knowledge Transfer: A Basis for Competitive Advantage in Firms. Organizational Behavior and Human Decision Processes, 82(1), 150-169.

Argote, L. \& Miron-Spektor, E. (2011). Organizational learning: from experience to knowledge. Organization Science, 22(5), 1123-1137.

Assudani, R. H. (2009). Ethnic Entrepreneurship: The Distinct Role of Ties. Journal of Small Business and Entrepreneurship, 22(2), 197-206.

Aurum, A., Daneshgar, F., \& Ward, J. (2008). Investigating Knowledge Management practices in software development organizations - An Australian experience. Information and Software Technology, 50(6), 511-533.

Babbie, E. R. (1990). Survey Research Methods. Belmont, CA: Wadsworth.

Barbosa, J. G. P., Monteiro, L. S. I., \& Freitas, J. A. S. B. (2012). Compartilhamento De Conhecimento: Um Estudo De Caso Em Uma Instituição Financeira. Perspectivas em Gestão \& Conhecimento, 2(1), 137-154.

Barney, J. (1991). Firm resources and sustained competitive advantage. Journal of Management, 77(1), 99-120.

Bartol, K. \& Srivastava, A. (2002). Encouraging knowledge sharing: the role of organizational reward systems. Journal of Leadership \& Organizational Studies, 9(1), 64-76.

Batista, F. F. (2012). Modelo de gestão do conhecimento para a administração pública brasileira: como implementar a gestão do conhecimento para produzir resultados em benefício do cidadão. Brasília: Ipea. 
Becerra-Fernandez, I. (2000). The Role of Artificial Intelligence Technologies in the Implementation of People-Finder Knowledge Management Systems. AAAI Technical Report, SS-00-03.

Bock, G. W., Zmud, R. W., Kim, Y. G., \& Lee, J. N. (2005). Knowledge sharing: examining the roles of extrinsic motivators, social-psychological forces, and organizational climate. MIS Quarterly, 29(1), 87-111.

Boh, W. F. (2007). Mechanisms for sharing knowledge in project-based organizations. Information and Organization, 17, 27-58.

Borgatti, S. P. \& Cross, R. (2003). A Relational View of Information Seeking and Learning in Social Networks. Management Science, 49(4), 432-445.

Bose, R. (2004). Knowledge management metrics. Industrial Management \& Data Systems, 104(6), 457-468.

Brown, T. A. (2006). Confirmatory factor analysis for applied research. New York: The Guilford Press.

Brown. J. S. \& Duguid, P. (2001). Knowledge and Organization: A Social-Practice Perspective. Organization Science, 12(2), 198-213.

Burrel, G. \& Morgan, G. (1979). Sociological paradigms and organizational analysis: elements of the sociology of corporate life. Londres: Heinemann.

Carbone, P. P. (2000). Cultura organizacional do setor público brasileiro: desenvolvendo uma metodologia de gerenciamento da cultura. Revista de Administração Pública, 34(2), 133-144. Cardoso, L. \& Gomes, D. (2011). Knowledge Mangement and Innovation: mapping the use of knowledge in organizations. In: Mesquita, A. Technology for creativity and innovation: tools, techniques and applications (pp. 237-266). Hershey: IGI Global.

Carmeli, A. \& Waldman, D. A. (2009). Leadership, behavioral context, and the performance of work groups in a knowledge-intensive setting. Journal of Technology Transfer, 35, 384-400. 
Carmeli, A., Gelbard, R., \& Reiter-Palmon, R. (2013). Leadership, creative problem-solving capacity, and reactive performance: the importance of knowledge sharing. Human Resource Management, 52(1), 95-122.

Castells, M. (2004). A galáxia da internet: reflexões sobre internet, negócios e sociedade. Lisboa: Fundação Calouste Gulbenkian.

Chiu, C. M., Hsu, M. H., \& Wang, E. T. G. (2006). Understanding knowledge sharing in virtual communities: an integration of social capital and social cognitive theories. Decision Support Systems, 42(3), 1872-1888.

Chiva, R. \& Alegre, J. (2005). Organizational learning and organizational knowledge: towards the integration of two approaches. Management Learning, 36(1), 49-68.

Choo, C. W. (2003). A Organização do Conhecimento. São Paulo: Editora Senac.

Coff, R. W., Coff, D. C., \& Eastvold, R. (2006). The Knowledge-Leveraging Paradox: How to Achieve Scale without Making Knowledge Imitable. Academy of Management Review, 31(2), $452-465$.

Cohen, J. (1988). Statistical Power Analysis for the Behavioral Sciences. Hillsdale, NJ: Erlbaum.

Comrey, A. L. \& Lee, H. B. (1992). A first course in factor analysis. (2nd ed.). Hillsdale, New Jersey: Lawrence Erlbaum Associates.

Consentino, H. M., Vidal, P. G., \& Virgillito, S. B. (2011). Gestão de Conhecimento e Competitividade nas Empresas de Pequeno Porte do Setor de Comércio Exterior de Autopeças: Um Estudo Exploratório. Revista de Administração e Inovação, 8(3), 100-119.

Creswell, J. W. (2010). Projeto de Pesquisa: Métodos Qualitativo, Quantitativo e Misto. (3a ed.). Porto Alegre: Artmed.

Crossan, M. M., Lane, H. W., \& White, R. E. (1999). An Organizational Learning Framework: from Intuition to Institution. Academy of Management Review, 24(3), 522-537. 
Damásio, B. F. (2012). Uso da análise fatorial exploratória em psicologia. Avaliação Psicológica,11(2), 213-228.

Davenport, T. H. \& Prusak, L. (1998) Conhecimento empresarial: Como as organizações gerenciam o seu capital intelectual. Rio de Janeiro: Editora Campus.

Dean, G. \& Gottschalk, P. (2007). Knowledge Management in Policing and Law enforcement: Foundations, Structures and applications. Oxford: Oxford University Press.

Dillon, W. R. \& Goldstein, M. (1984). Multivariate Analysis: Methods and Applications. New York: Wiley.

Dodgson, M. (1993). Organizational learning: a review of some literatures. Organization Studies, 14, 375-394.

Donaldson, S. I. \& Grant-Valone, E. J. (2002). Understanding self-report in Organizational Behavior research. Journal of Business and Psychology, 17(2), 245-260.

Edwards, J. R. \& Barry, J. W. (2010). The presence of something or the absence of nothing: increasing theoretical precision in management research. Organization Research Methods, 13(4), 668-689.

Evans, M. M. \& Alleyne, J. (2009). The Concept of Knowledge in KM: A Knowledge Domain Process Model Applied to Inter-Professional Care. Knowledge and Process Management, 16(4), 147-161.

Faoro, R. R. \& Oliveira, M. (2014). Compartilhamento do Conhecimento Intraorganizacional e Interorganizacional: Empresas do Setor de Fruticultura. Perspectiva em Gestão \& Conhecimento, 4(1), 98-18.

Fávero, L. P. L. (2005). O mercado imobiliário residencial da região metropolitana de São Paulo: uma aplicação de modelos de comercialização hedônica de regressão e correlação canônica (Tese de Doutorado). Universidade de São Paulo, São Paulo, SP, Brasil.

Field, A. (2009). Discovering Statistics Using SPSS. (3rd ed.). London: SAGE Publications. 
Foray, D. (2004). The Economics of Knowledge. Cambridge: MIT Press.

Freitas, H., Oliveira, M., Saccol, A. Z., \& Moscarolla, J. (2000). O Método de Pesquisa Survey. Revista de Administração, 35(3), 105-112.

Frost, T. S., Birkinshaw, J. M., \& Ensign, P. C. (2002). Centers of excellence in multinational corporations. Strategic Management Journal, 23, 997-1018.

Gelis Filho, A. (2006). Análise Comparativa do Desenho Normativo de Instituições Reguladoras do Presente e do Passado. Revista de Administração Pública, 40(4), 589-613.

Gherardi, S. (2009). Introduction: The Critical Power of the 'Practice Lens'. Mangement Learning, 40(2), 115-128.

Gherardi, S. \& Nicolini, D. (2000). To transfer is to transform: the circulation of safety knowledge. Organization, 7(2), 329-348.

Godoi, C. K., Bandeira-de-Mello, R., \& Silva, A. B. (2010). Pesquisa qualitativa em estudos organizacionais: paradigmas, estratégias e métodos. (2a ed.). São Paulo: Saraiva.

Gourlay, S. \& Nurse, A. (2005). Flaws in the "engine" of knowledge creation: A critique of Nonaka's theory. Issues in Knowledge Management. Greenwich: IAP Press.

Gourlay, S. (2006). Conceptualizing knowledge creation: A critique of Nonaka's theory. Journal of Management Studies, 43(7), 1415-1436.

Guba, E. G. (1990). The paradigm dialog. Newbury Park: Sage.

Gunther, H. (1999). Como elaborar um questionário. In: Pasquali, L. (Org.). Instrumentos Psicológicos: Manual Prático de Elaboração. Brasília: LabPALM, pp. 231-258.

Hair, J. F., Babin, B., Money, A. H., \& Samouel, P. (2005). Fundamentos de métodos de pesquisa administração. Porto Alegre: Bookman.

Hair, J. F., Black, W. C., Babin, B. J., Anderson, R. E., \& Tatham, R. L. (2010). Análise Multivariada de Dados. (7a ed.). Porto Alegre: Bookman. 
Hamel, G. (2009). Moon Shots for Management. Harvard Business Review, Reprint R0902H, $1-10$.

Hansen, M. T. \& Nohria, N. (1999). What's your strategy for managing knowledge? Harvard Business Review, Mar-Apr, 106-116.

Hartung, K. \& Oliveira, M. (2013). Communities of practice: creating and sharing knowledge. Revista de Gestão, 20(3), 407-422.

Hatch, M. J. (1997). Organization theory. Oxford: University Press.

Hayes, N. \& Walsham, G. (2001). Participation in groupware-mediated communities of practice: a socio-economic analysis of knowledge working. Information and Organization, 11(4), 263-288.

He, H., Baruch, Y., \& Lin, C. P. (2014). Modeling team knowledge sharing and team flexibility: the role of within-team competition. Human Relations, 67(8), 947-978.

Heisig, P. (2009). Harmonisation of knowledge management - comparing $160 \mathrm{KM}$ frameworks around the globe. Journal of Knowledge Management, 13(4), 4-31.

Hendriks, P. (1999). Why Share Knowledge? The Influence of ICT on the Motivation for Knowledge Sharing. Knowledge and Process Management, 6(2), 91-100.

Hong, J. F. L. (2011). Glocalizing Nonaka's knowledge creation model: Issues and challenges. Management Learning, 43(2), 199 -215.

Hotelling, H. (1936). Relations between Two Sets of Variates. Biometrika, 28(3/4), 321-377. Huang, Q., Davison, R. M, \& Gu, J. (2008). Impact of personal and cultural factors on knowledge sharing in China. Asia Pacific Journal of Management, 25, 451-471.

Huang, C. C. (2009). Knowledge sharing and group cohesiveness on performance: An empirical study of technology R\&D teams in Taiwan. Technovation, 29, 786-797.

Huber, G. P. (2001). Transfer of knowledge in knowledge management systems: unexplored issues and suggested studies. European Journal of Information Systems, 10, 72-79. 
Hunter, J. E. \& Schmidt, F. L. (2004). Methods of Meta-Analysis: Correcting Error and Bias in Research Findings. Newbury Park, CA: Sage.

Ipe, M. (2003). Knowledge sharing in organizations: a conceptual framework. Human Resource Development Review, 2(4), 337-359.

Joia, L. A. \& Oliveira, M. F. B. (2007). Personalização ou codificação? Avaliando estratégias de foco em gestão do conhecimento. Organizações \& Sociedade, 14(43), 13-36.

Kaiser, H. F. (1974). An index of factorial simplicity. Psychometrika, 39(1), 31-36.

Kim, Y. G., Yu, S. H., \& Lee, J. H. (2003). Knowledge strategy planning: methodology and case. Expert Systems with Applications, 24, 295-307.

Kogut, B. \& Zander, U. (1992). Knowledge of the Firm, Combinative Capabilities, and the Replication of Technology. Organization Science, 3(3), 383- 397.

Lambert, Z. V. \& Durand, R. M. (1975). Some Precautions in Using Canonical Analysis. Journal of Marketing Research, 12(4), 468-475.

Lane, P. J., Koka, B. R., \& Pathak, S. (2006). The reification of absorptive capacity: a critical review and rejuvenation of the construct. Academy of Management Review, 31(4), 833-863.

Laros J. A. \& Puente-Palacios K. E. (2004). Validação cruzada de uma escala de clima social. Estudos de Psicologia, 9(1), 113-119.

Liepshitz, R. \& Popper, M. (1996). Building learning organizations: the design and implementation of organizational learning mechanism. The Journal of Applied Behavioral Science, 32(3), 292-305.

Liepshitz, R., Popper, M., \& Friedman, V. J. (2002). A Multifacet Model of Organizational Learning. The Journal of Applied Behavioral Science, 38(1), 78-98.

Lim, D. \& Klobas, J. (2000). Knowledge management in small enterprises. The Electronic Library, 18(6), 420-432. 
Lópes, S. P., Léon, J. M. M., \& Ordás, C. J. V. (2005). Organizational Learning as a Determining Factor in Business Performance. The Learning Organization, 12(3), 227-245.

Lucchi, M., Bianco, M. F., \& Lourenção, P. T. M. (2011). Work in Multidisciplinary Teams: a Study about Mobilization of Knowledge and Learning in an Organization of Complex Products. Brazilian Administration Review, 8(3), 305-328.

MacCalum, R. C., Widaman, K. F., Zhang, S., \& Hong, S. (1999). Sample size in factor analysis. Psychological Methods, 4(1), 84-99.

Malecki, E. J. (2010). Everywhere? The geography of knowledge. Journal of Regional Science, 50(1), 493-513.

Martelane, R. (1991). O relacionamento entre os corpos permanentes e não-permanentes na organização pública - um modelo. Anais do Encontro Nacional da Associação Nacional de Pós-Graduação e Pesquisa em Administração, Salvador, BA, Brasil, 15.

Mead, G. H. (1967). Mind, Self, and Society: From the Standpoint of a Social Behaviorist. Chicago: Chicago University Press.

Mezias, J., Grinyer, P., \& Guth, W. D. (2001). Changing collective cognition: a process model for strategic change. Long Range Planning, 34(1), 71-95.

Moresi, E. A. D. \& Mendes, S. P. (2010). Compartilhamento do conhecimento em portais corporativos. Transinformação, 22(1), 19-32.

Nadler, J., Thompson, L., \& L. Van Boven. (2003). Learning negotiation skills: Four models of knowledge creation and transfer. Management Science, 49(4), 529-540.

Nahapiet, J. \& Ghoshal, S. (1998). Social Capital, Intellectual Capital, and the Organizational Advantage. Academy of Management Review, 23(2), 242-266.

Ndlela, L. T. \& du Toit, A. S. A. (2001). Establishing a knowledge management programme for competitive advantage in an enterprise. International Journal of Information Management, $21,151-165$. 
Nelson, R. R. \& Winter, S. G. (1982). An Evolutionary of Economic Change. Cambridge: Harvard University Press Belknap Press.

Nonaka, I. (1994). A dynamic theory of organizational knowledge creation. Organization Science, 5(1), 14-37.

Nonaka, I. \& Konno, N. (1998). The concept of "Ba": Building a Foundation for Knowledge Creation. California Management Review, 40(3), 40-54.

Nonaka, I. \& Takeuchi, H. (1995). The Knowledge-Creating Company: How Japanese Companies Create the Dynamics of Innovation? Oxford: Oxford University Press.

Nonaka, I., Toyama, R., \& Konno, N. (2000). SECI, Ba and leadership: A unified model of dynamic knowledge creation. Long Range Planning, 33(1), 5-34.

Nonaka, I. \& Von Krogh, G. (2009). Tacit Knowledge and Knowledge Conversion: Controversy and Advancement in Organizational Knowledge Creation Theory. Organization Science, 20(3), 635-652.

Oliveira, M., Caldeira, M. \& Romão, M. (2012). Knowledge management implementation: an evolutionary process in organizations. Knowledge and Process Management, 19(1), 17-26.

Oliveira Junior, M. M. (1999). Core Competencies and the Knowledge of the Firm. In: Hitt, M. A., Clifford, P. G., Nixon, R. D., \& Coyne, K. P. (Org.). Dynamic Strategic Resources: Development Diffusion and Integration. Chichester: West Sussex: John Wiley and Sons, 1741.

Özbebek, A. \& Toplu, E. K. (2011). Empowered employees’ knowledge sharing behavior. International Journal of Business and Management Studies, 3,69-76.

Palacios-Marqués, D., Peris-Ortiz, M., \& Merigó, J. M. (2013). The effect of knowledge transfer on firm performance: An empirical study in knowledge-intensive industries. Management Decision, 51, 973-85. 
Panahi, S., Watson, J., \& Partridge, H. (2013). Towards tacit knowledge sharing over social web tools. Journal of Knowledge Management, 17(3), 379-397.

Pasquali, L. (1997). Psicometria: Teorias e Aplicações. Brasília: Universidade de Brasília.

Pasquali, L. (2005). Análise fatorial para pesquisadores. Brasília: LabPAM.

Pasquali, L. (2010). Instrumentos Psicológicos: Fundamentos e Práticas. Porto Alegre: Artmed.

Penrose, E. T. (1959). The Theory of the Growth of the Firm. Nova Iorque: Oxford University Press.

Peteraf, M. A. (1993). The cornerstone of competitive advantage: a resource-based view. Strategic Management Journal, 14, 179-191.

Pires, J. C. S. \& Macêdo, K. B. (2006). Cultura organizacional em organizações públicas no Brasil. Revista de Administração Pública, 40(1), 81-105.

Pokharel, M. P. \& Choi, S. A. (2015). Exploring the relationships between the learning organization and organizational performance. Management Research Review, 38(2), 126-148. Polanyi, M. (1962). The tacit dimension. London: Routdedge \& Kegan Paul.

Porter, M. E. \& Millar, V. E. (1985). How Information Gives You Competitive Advantage. Harvard Business Review, Reprint 85415.9

Prahalad, C. K. \& Hamel, G. (1990). The Core Competence of the Corporation. Havard Business Review, Reprint 90311.

Probst, G., Raub, S., \& Romhardt, K. (2002). Gestão do Conhecimento: Os Elementos Constitutivos do Sucesso. Porto Alegre: Bookman.

Ragab, M. A. F. \& Arisha, A. (2013). Knowledge management and measurement: a critical review. Journal of Knowledge Management, 17(6), 873-901. 
Ramayah, T., Yeap, J. A. L., \& Ignatius, J. (2014). Assessing Knowledge Sharing Among Academics: A Validation of the Knowledge Sharing Behavior Scale (KSBS). Evaluation Review, 38(2), 160-187.

Reed, R. \& DeFillippi, R. J. (1990). Causal ambiguity, barriers to imitation, and sustainable competitive advantage. Academy Management Review, 15(1), 88-102.

Ribeiro, R. \& Collins, H. (2007). The bread-making machine: Tacit knowledge and two types of action. Organization Studies, 28(9), 1417-1433.

Riege, A. \& Lindsay, N. (2006). Knowledge management in the public sector: stakeholder partnerships in the public policy development. Journal of Knowledge Management, 10(3), 2439.

Rozzett, K. \& Demo, G. (2010). Desenvolvimento e Validação Fatorial da Escala de Relacionamento com Clientes (ERC). Revista de Administração de Empresas, 50(4), 383-395. Sá, F. B., Bento, K. G. R., Ziviani, F., \& Ferreira, M. A. T. (2013). Práticas de Gestão do Conhecimento: um Estudo em Organizações Mineiras. Perspectivas em Gestão \& Conhecimento, 3(1), 114-131.

Sabherwal, R. \& Becerra-Fernandez, I. (2003). An Empirical Study of the Effect of Knowledge Management Processes at Individual, Group, and Organizational Levels. Decision Sciences, $34(2), 225-260$.

Saito, A., Umemoto, K., \& Ikeda, M. (2007). A strategy-based ontology of knowledge management technologies. Journal of Knowledge Management, 11(1), 97-114.

Scarbrough, H., Swan, J., Laurent, S., Bresnen, M., Edelman, L., \& Newell, S. (2004). ProjectBased Learning and the Role of Learning Boundaries. Organization Studies, 25(9), 1579-1600. Schall, E. (1997). Public sector succession: a strategic approach to sustaining innovation. Public Administration Review, 57(1), 4-10. 
Schmitt, T. A. \& Sass, D. A. (2011). Rotation criteria and hypothesis testing for exploratory fator analysis: Implications for factor pattern loadings and interfactor correlations. Educational and Psychological Measurement, 71(1), 95-113.

Senge, P. M. (1993). A quinta disciplina: A arte e prática da organização que aprende. Rio de Janeiro: Campus.

Shepherd, G. \& Valencia, S. (1996). Modernizando a administração pública na América Latina: problemas comuns sem soluções fáceis. Revista do Serviço Público, 120(3), 103-128.

Shrivastava, P. (1983). A Typology of Organizational Learning Systems. Journal of Management Studies, 20(1), 7-28.

Isidro-Filho, A. I. (2009). Mecanismos de Aprendizagem em Organizações: Desenvolvimento e Validação de uma Escala de Medida. Revista de Administração Mackenzie, 10(1), 37-57.

Sinkula, J. M. (1994). Market information processing and organizational learning. Journal of Marketing, 58, 35-45.

Siong, C. C., Salleh, K., Syed Noh Syed, A., \& Syed-Ikhsan, S. O. S. (2011). KM implementation in a public sector accounting organization: an empirical investigation. Journal of Knowledge Management, 15(3), 497-512.

Sirmon, D. G., Hitt, M. A., \& Ireland, R. D. (2007). Managing firm resources in dynamic environments to create value: looking inside the black box. Academy of Management Review, 32(1), 273-92.

Slater, S. \& Narver, J. (1995). Market Orientation and the Learning Organization. Journal of Marketing, 59, 63-74.

Song, J. H., Kolb, J. A., Lee, U. H., \& Kim, H. K. (2012). Role of transformational leadership in effective organizational knowledge creation practices: mediating effects of employees' work engagement. Human Resource Development Quarterly, 23(1), 65-101. 
Song, J. H., Yoon, S. W., \& Uhm, D. (2012). Systematic and practical measurement of organizational knowledge creation. Leadership \& Organization Development Journal, 33(7), 616-631.

Souto, P. C. N. (2013). Beyond knowledge, towards knowing: the practice-based approach to support knowledge creation, communication, and use for innovation. Revista de Administração e Inovação, 10(1), 51-78.

Spender, J. C. (1996). Making knowledge the basis of a dynamic theory of the firm. Strategic Management Journal, 17, 45-62.

Stewart, T. A. (1998). Capital Intelectual. Rio de Janeiro: Campus.

Stewart, Douglas, K., \& Love, W. A. J. (1968). A General Can-onical Correlation Index. Psychological Bulletin, 70, 160-3.

Styhre, A., Ollila, S., Roth, J., Williamson, D., \& Berg, L. (2008). Heedful interrelating, knowledge sharing, and new drug development. Journal of Knowledge Management, 12(3), $127-140$.

Sun, P. (2010). Five critical knowledge management organizational themes. Journal of Knowledge Management, 14(4), 507-523.

Sveiby, K. E. (2007). Disabling the context for knowledge work: the role of managers' behaviours. Management Decision, 45(10), 1636-1655.

Szulanski, G. (1996). Exploring Internal Stickiness: Impediments to the Transfer of Best Practice Within the Firm. Strategic Management Journal, 17, 27-43.

Szulanski, G. (2000). The process of knowledge transfer: a diachronic analysis of stickness. Organizational Behavior and Human Decision Processes, 82(1), 9-27.

Tabachnick, B. G. \& Fidell, L. S. (2007). Using Multivariate Statistics. (5th ed.). New York: Harper \& Row Collins College Publishers. 
Teece, D. J. (1982). Towards an economic theory of the multiproduct firm. Journal of Economic Behavior and Organization, 3(1), 39-63.

Teece, D. J., Pisano, G., \& Shuen, A. (1998). Dynamic capabilities and strategic management. Strategic Management Journal, 18(7), 509-533.

Terra, J. C. C. (2001). Gestão do Conhecimento: Aspectos Conceituais e Estudo Exploratório sobre as Práticas de Empresas Brasileiras. In Fleury, M. T. L. \& Oliveira Jr., M. M. (Orgs.). Gestão Estratégica do Conhecimento: Integrando aprendizagem, conhecimento e competências (pp. 212-241). São Paulo: Atlas.

Tonet, H. C. \& Paz, M. G. T. (2006). Um modelo para o compartilhamento do conhecimento no trabalho. Revista de Administração Contemporânea, 10(2), 75-94.

Triviños, A. N. S. (1987). Introdução à pesquisa em ciências sociais: a pesquisa qualitativa em educação. São Paulo: Atlas.

Tseng, S. M. (2008). Knowledge management system performance measure index. Expert Systems with Applications, 34, 734-745.

Tseng, S. M. (2010). The effects of hierarchical culture on knowledge management processes. Management Research Review, 33(8), 827-839.

Tsoukas, H. (2003). Do we really understand tacit knowledge? In Easterby-Smith, M. \& Lyles, M. A. (Eds.). Handbook of Organizational Learning and Knowledge Management (pp. 410427). Oxford: Blackwell Publishing.

Tsoukas, H. (2009). A Dialogical Approach to the Creation of New Knowledge in Organizations. Organization Science, 20(6), 941-957.

van Wijk, R., Jansen, J. J. P., \& Lyles, M. A. (2008). Inter- and Intra-Organizational Knowledge Transfer: A Meta-Analytic Review and Assessment of its Antecedents and Consequences. Journal of Management Studies, 45(4), 830-853. 
Vasconcelos, K. C. A., Merhi, D. Q., Junior, A. S., \& Silva, P. O. M. (2013). Cultura, Liderança

e Compartilhamento do Conhecimento Organizacional. Revista de Administração FACES, 12(1), 13-31.

von Krogh, G., Ichijo, K., \& Nonaka, I. (2000). Enabling Knowledge Creation: How to Unlock the Mystery of Tacit Knowledge and Release the Power of Innovation. Nova Iorque: Oxford University Press.

von Krogh, G., Nonaka, I., \& Rechsteiner, L. (2012). Leadership in Organizational Knowledge Creation: A Review and Framework. Journal of Management Studies, 49 (1), 240-277.

von Hippel, E. (1994). "Sticky Information" and the Locus of Problem Solving: Implications for Innovation. Management Science, 40(4), 429-439.

Wee, J. C. N. \& Chua, A. Y. K. (2013). The peculiarities of knowledge management processes in SMEs: the case of Singapore. Journal of Knowledge Management, 17(6), 958-972.

Wenger, E. C., McDermott, R., \& Snyder, W. C. (2002). Cultivating communities of practice: a guide to managing knowledge. Boston, MA: Harvard Business.

Wiig, K. M. (2002). Knowledge management in public administration. Journal of Knowledge Management, 6(3), 224-239.

Wiig, K. M. \& Jooste, A. (2003). Exploiting knowledge for productivity gains. In Holsapple, C. W. (Ed.). Handbook on Knowledge Management: Volume 2 (pp. 289-308). Berlin: SpringerVerlag.

Williamson, O. E. (1975). Markets and Hierarchies: Analysis and Antitrust Implications. Nova Iorque: The Free Press.

Xavier, L. A O. P., Oliveira, M., \& Teixeira, E. K. (2012). Teorias utilizadas nas investigações sobre gestão do conhecimento. Revista Ibérica de Sistemas e Tecnologia da Informação, 10, 117. 
Xue, Y., Bradley, J., \& Liang, H. (2011). Team climate, empowering leadership, and knowledge sharing. Journal of Knowledge Management, 15(2), 299-312.

Yang, C. \& Chen, L. C. (2007). Can organizational knowledge capabilities affect knowledge sharing behavior? Journal of Information Science, 33 (1), 95-109.

Yi, J. (2009). A measure of knowledge sharing behavior: Scale development and validation. Knowledge Management Research \& Practice, 7, 65-81.

Zahra, S. \& George, G. (2002). Absortive Capacity: A Review, Reconceptualization, and Extension. Academy of Management Review, 27(2), 185-203.

Zander, U. \& Kogut, B. (1995). Knowledge and the Speed of the Transfer and Imitation of Organizational Capabilities: an Empirical Test. Organization Science, 6(1), 76-92.

Zellmer-Bruhn, M. E. (2003). Interruptive Events and Team Knowledge Acquisition. Management Science, 49(4), 514-528. 
ANEXOS

\begin{abstract}
ANEXO A
Escalas de Mecanismos de Aprendizagem e de Compartilhamento do Conhecimento Aplicadas nas Organizações Militares
\end{abstract}

Prezado,

Este questionário é parte da minha pesquisa de dissertação de Mestrado realizada no âmbito do Programa de Pós-Graduação em Administração da Universidade de Brasília (UnB), cujo objetivo é descrever a relação existente entre as condições proporcionadas pela organização para o compartilhamento do conhecimento e o próprio compartilhamento do conhecimento no ambiente organizacional.

O acesso ao questionário será proporcionado por meio de um link do site SurveyMonkey, o qual segue logo abaixo. Todos os itens são analisados em uma escala de cinco pontos, variando de "nunca ocorre" a "sempre ocorre". Além disso, há espaços para captar dados funcionais e biográficos dos respondentes, de modo a verificar possíveis diferenças de respostas em decorrência desses dados. O tempo estimado para preenchimento do questionário é de 15 minutos.

Todos os dados provenientes da pesquisa serão tratados de forma reservada, ou seja, as informações solicitadas não permitirão a identificação dos respondentes, pois os resultados serão processados de maneira global.

A sua participação é essencial para o alcance dos resultados da pesquisa e a conclusão da dissertação. Conto com vossa colaboração, colocando-me à disposição para eventuais esclarecimentos, por meio dos emails fabiosilvaffs@copac.aer.mil.br ou fabiosilvaffs96@gmail.com, ou ainda no telefone (61) 8207-2992.

Desde já agradeço a compreensão! 
PARTE I - Condições Proporcionadas pela Organização.

Esta parte é composta de itens que abrangem condições proporcionadas pela organização para a interação entre os indivíduos no ambiente de trabalho.

Assinale as assertivas, levando em consideração a escala de frequência abaixo.

\begin{tabular}{|c|c|c|c|c|}
\hline 1 & 2 & 3 & 4 & 5 \\
\hline Nunca ocorre & $\begin{array}{c}\text { Poucas vezes } \\
\text { ocorre }\end{array}$ & Às vezes ocorre & $\begin{array}{c}\text { Ocorre muitas } \\
\text { vezes }\end{array}$ & Sempre ocorre \\
\hline
\end{tabular}

\begin{tabular}{|c|c|c|c|c|c|c|}
\hline \multirow{2}{*}{$\mathrm{N}^{\mathrm{o}}$} & \multirow{2}{*}{ Assertiva } & \multicolumn{5}{|c|}{ Opções de Resposta } \\
\hline & & 1 & 2 & 3 & 4 & 5 \\
\hline 1 & $\begin{array}{l}\text { A organização incentiva seus integrantes a participar de grupos } \\
\text { externos e redes de pessoas. }\end{array}$ & & & & & \\
\hline 2 & $\begin{array}{l}\text { A organização promove parcerias com outras organizações, tais } \\
\text { como universidades, empresas privadas e ONG. }\end{array}$ & & & & & \\
\hline 3 & $\begin{array}{l}\text { A organização mantém contatos com profissionais e especialistas } \\
\text { externos. }\end{array}$ & & & & & \\
\hline 4 & $\begin{array}{l}\text { A organização incentiva que os indivíduos proponham novas } \\
\text { ideias em relação aos assuntos de trabalho. }\end{array}$ & & & & & \\
\hline 5 & $\begin{array}{l}\text { A organização oferece oportunidades de aprendizagem, tais como } \\
\text { programas internos de capacitação, visitas técnicas a outros } \\
\text { departamentos. }\end{array}$ & & & & & \\
\hline 6 & $\begin{array}{l}\text { A organização identifica indivíduos da própria organização com } \\
\text { expertise em assuntos específicos, por meio de catálogos ou } \\
\text { quaisquer outras formas de registro. }\end{array}$ & & & & & \\
\hline 7 & $\begin{array}{l}\text { A organização proporciona meios para que seus integrantes } \\
\text { participem de eventos externos (ex.: congressos, feiras e } \\
\text { simpósios). }\end{array}$ & & & & & \\
\hline 8 & $\begin{array}{l}\text { A organização proporciona ao público interno a consulta às bases } \\
\text { de dados ou repositório de documentos por meio de algum tipo de } \\
\text { rede interna (ex.: intranet). }\end{array}$ & & & & & \\
\hline 9 & $\begin{array}{l}\text { A organização propicia ambientes informais para que os } \\
\text { indivíduos compartilhem conhecimentos e experiências entre } \\
\text { colegas de trabalho. }\end{array}$ & & & & & \\
\hline 10 & $\begin{array}{l}\text { A organização incentiva que os indivíduos compartilhem } \\
\text { sugestões no ambiente de trabalho. }\end{array}$ & & & & & \\
\hline 11 & A organização fomenta o trabalho em equipe. & & & & & \\
\hline 12 & $\begin{array}{l}\text { A organização incentiva que novas ideias e abordagens sobre } \\
\text { desempenho no trabalho sejam aplicadas no dia-a-dia. }\end{array}$ & & & & & \\
\hline 13 & $\begin{array}{lll}\text { A organização proporciona encontros para informar aos } \\
\text { indivíduos a respeito de inovações em suas atividades. }\end{array}$ & & & & & \\
\hline 14 & $\begin{array}{l}\text { A organização realiza mudanças de profissionais entre } \\
\text { departamentos e funções, proporcionando a participação do } \\
\text { indivíduo em outras equipes. }\end{array}$ & & & & & \\
\hline 15 & $\begin{array}{l}\text { A organização incentiva o rodízio de tarefas entre os profissionais } \\
\text { da organização. }\end{array}$ & & & & & \\
\hline 16 & $\begin{array}{l}\text { A organização informa seus integrantes a respeito de } \\
\text { responsabilidades de outros colegas de trabalho e departamentos. }\end{array}$ & & & & & \\
\hline
\end{tabular}




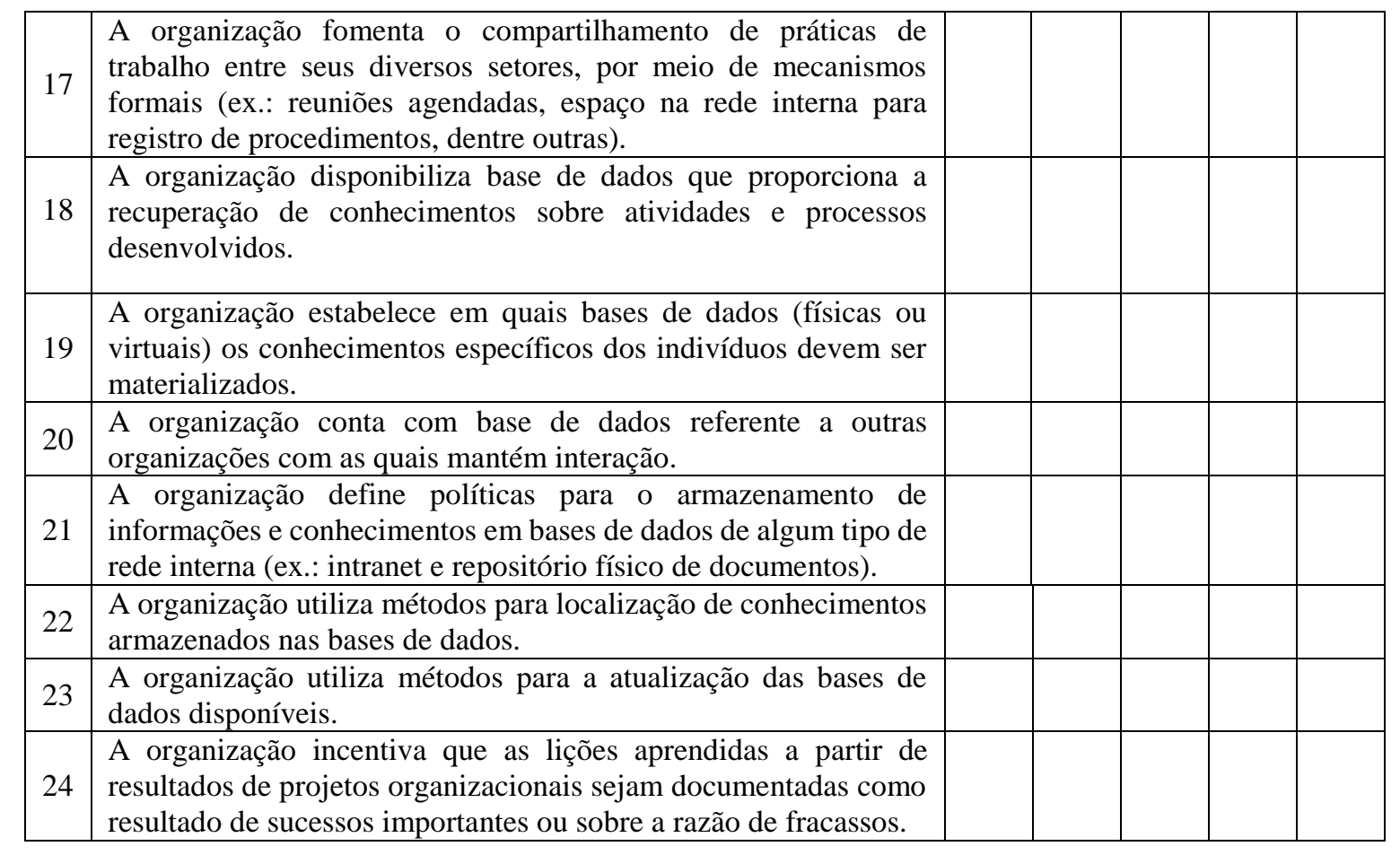

\section{PARTE II - AÇÃO DE INTERAÇÃO COM FONTES DE CONHECIMENTO}

Esta parte é composta por itens que abordam a sua interação com diferentes fontes de conhecimento da organização.

Assinale as assertivas, levando-se em consideração a escala de frequência abaixo.

\begin{tabular}{|c|c|c|c|c|}
\hline 1 & 2 & 3 & 4 & 5 \\
\hline Nunca ocorre & $\begin{array}{c}\text { Poucas vezes } \\
\text { ocorre }\end{array}$ & Às vezes ocorre & $\begin{array}{c}\text { Ocorre muitas } \\
\text { vezes }\end{array}$ & Sempre ocorre \\
\hline
\end{tabular}

\begin{tabular}{|c|l|l|c|c|c|}
\hline \multirow{2}{*}{$\mathrm{N}^{\mathbf{0}}$} & \multicolumn{1}{|c|}{ Assertiva } & \multicolumn{3}{|c|}{ Opções de Resposta } \\
\cline { 2 - 5 } 25 & $\begin{array}{l}\text { Mantenho interação com grupos ou redes de pessoas na } \\
\text { organização. }\end{array}$ & & & & \\
\hline 26 & $\begin{array}{l}\text { Participo de grupos ou redes de pessoas externos à organização } \\
\text { que possuem afinidade com a minha atividade profissional. }\end{array}$ & & & & \\
\hline 27 & $\begin{array}{l}\text { Mantenho contato com especialistas da organização com } \\
\text { conhecimento reconhecido em temas específicos. }\end{array}$ & & & & \\
\hline 28 & $\begin{array}{l}\text { Participo de programas de aprendizagem, tais como atividades } \\
\text { internas de capacitação, cursos e visitas técnicas a outras } \\
\text { organizações. }\end{array}$ & & & & \\
\hline 29 & $\begin{array}{l}\text { Utilizo o conhecimento adquirido nas atividades internas, (ex.: } \\
\text { ações de capacitação interna e reuniões de trabalho) para a } \\
\text { consecução de objetivos organizacionais. }\end{array}$ & & & \\
\hline 30 & \begin{tabular}{l} 
Desenvolvo minhas atividades na organização em equipe. \\
\hline
\end{tabular} & & & & \\
\hline
\end{tabular}




\begin{tabular}{|l|l|l|l|l|l|}
\hline 31 & $\begin{array}{l}\text { Converso com outros colegas sobre assuntos relacionados ao } \\
\text { trabalho em encontros casuais (ex.: por exemplo, intervalo do café } \\
\text { e confraternizações da organização). }\end{array}$ & & & & \\
\hline 32 & $\begin{array}{l}\text { Utilizo o conhecimento fruto das conversas com meus colegas da } \\
\text { organização para a resolução de problemas do trabalho. }\end{array}$ & & & \\
\hline 33 & $\begin{array}{l}\text { Compartilho conhecimento relacionado com as atividades que } \\
\text { realizo em reuniões de trabalho. }\end{array}$ & & & \\
\hline 34 & $\begin{array}{l}\text { Utilizo ambientes virtuais (ex.: e-mail, rede intranet e } \\
\text { teleconferência) para interação com colegas de trabalho. }\end{array}$ & & & \\
\hline 35 & $\begin{array}{l}\text { Desenvolvo novas ideias e conceitos por meio de diálogos com } \\
\text { colegas de trabalho. }\end{array}$ & & & \\
\hline 36 & $\begin{array}{l}\text { Assimilo conhecimentos por meio de observações, imitações ou } \\
\text { práticas de colegas de trabalho. }\end{array}$ & & & \\
\hline 37 & $\begin{array}{l}\text { Durante as atividades diárias exponho o meu conhecimento por } \\
\text { meio de analogias e exemplos. }\end{array}$ & & & \\
\hline 38 & $\begin{array}{l}\text { Compartilho conhecimento com colegas de trabalho por meio de } \\
\text { documentos e/ou repositórios virtuais de documentos. }\end{array}$ & & & & \\
\hline 39 & $\begin{array}{l}\text { Utilizo o conhecimento armazenado nas bases de dados físicas e } \\
\text { virtuais da organização. }\end{array}$ & & & & \\
\hline
\end{tabular}

\section{PARTE III - DADOS BIOGRÁFICOS E FUNCIONAIS}

Os próximos campos possuem a finalidade de captar algumas características da amostra de respondentes.

40- Sexo:

( ) Masculino ( ) Feminino

41- Idade:

42- Nível de escolaridade:

( ) Técnico ( ) Graduação ( ) Especialização ( ) Mestrado ( ) Doutorado

43- Tempo no (__ $)$ :

44- Setor de atuação na organização:

45 - Função atual:

46 - Tempo na atual função: 


\begin{abstract}
ANEXO B
Escalas de Mecanismos de Aprendizagem e de Compartilhamento do Conhecimento Aplicadas nos ATPS
\end{abstract}

Prezado,

Este questionário é parte da minha pesquisa de dissertação de Mestrado realizada no âmbito do Programa de Pós-Graduação em Administração da Universidade de Brasília (UnB), sob orientação da Profa. Dra. Catarina Odelius. A pesquisa é para subsidiar a elaboração da dissertação, cujo objetivo é descrever a relação existente entre as condições proporcionadas pela organização para o compartilhamento do conhecimento e o próprio compartilhamento do conhecimento no ambiente organizacional.

O acesso ao questionário será proporcionado por meio de um link do site SurveyMonkey, o qual segue logo abaixo. Todos os itens são analisados em uma escala de cinco pontos, variando de "nunca ocorre" a "sempre ocorre". Além disso, há espaços para captar dados funcionais e biográficos dos respondentes, de modo a verificar possíveis diferenças de respostas em decorrência desses dados. O tempo estimado para preenchimento do questionário é de 10 minutos.

Todos os dados provenientes da pesquisa serão tratados de forma reservada, ou seja, as informações solicitadas não permitirão a identificação dos respondentes, pois os resultados serão processados de maneira global.

A sua participação é essencial para o alcance dos resultados da pesquisa e a conclusão da dissertação. Conto com vossa colaboração, colocando-me à disposição para eventuais esclarecimentos, por meio dos emails fabiosilvaffs@copac.aer.mil.br ou fabiosilvaffs96@gmail.com, ou ainda no telefone (61) 8207-2992.

Desde já agradeço a compreensão! 
PARTE I - Condições Proporcionadas pela Organização.

Esta parte é composta de itens que abrangem condições proporcionadas pela organização para a interação entre os indivíduos no ambiente de trabalho.

Assinale as assertivas, levando em consideração a escala de frequência abaixo.

\begin{tabular}{|c|c|c|c|c|}
\hline 1 & 2 & 3 & 4 & 5 \\
\hline Nunca ocorre & $\begin{array}{c}\text { Poucas vezes } \\
\text { ocorre }\end{array}$ & Às vezes ocorre & $\begin{array}{c}\text { Ocorre muitas } \\
\text { vezes }\end{array}$ & Sempre ocorre \\
\hline
\end{tabular}

\begin{tabular}{|c|c|c|c|c|c|c|}
\hline \multirow{2}{*}{$\mathrm{N}^{\mathrm{o}}$} & \multirow{2}{*}{ Assertiva } & \multicolumn{5}{|c|}{ Opções de Resposta } \\
\hline & & 1 & 2 & 3 & 4 & 5 \\
\hline 1 & $\begin{array}{l}\text { A organização incentiva seus integrantes a participar de grupos } \\
\text { externos e redes de pessoas. }\end{array}$ & & & & & \\
\hline 2 & $\begin{array}{l}\text { A organização promove parcerias com outras organizações, tais } \\
\text { como universidades, empresas privadas e ONG. }\end{array}$ & & & & & \\
\hline 3 & $\begin{array}{l}\text { A organização mantém contatos com profissionais e especialistas } \\
\text { externos. }\end{array}$ & & & & & \\
\hline 4 & $\begin{array}{l}\text { A organização incentiva que os indivíduos proponham novas } \\
\text { ideias em relação aos assuntos de trabalho. }\end{array}$ & & & & & \\
\hline 5 & $\begin{array}{l}\text { A organização oferece oportunidades de aprendizagem, tais como } \\
\text { programas internos de capacitação, visitas técnicas a outros } \\
\text { departamentos. }\end{array}$ & & & & & \\
\hline 6 & $\begin{array}{l}\text { A organização identifica indivíduos da própria organização com } \\
\text { expertise em assuntos específicos, por meio de catálogos ou } \\
\text { quaisquer outras formas de registro. }\end{array}$ & & & & & \\
\hline 7 & $\begin{array}{l}\text { A organização proporciona meios para que seus integrantes } \\
\text { participem de eventos externos (ex.: congressos, feiras e } \\
\text { simpósios). }\end{array}$ & & & & & \\
\hline 8 & $\begin{array}{l}\text { A organização proporciona ao público interno a consulta a bases } \\
\text { de dados ou repositório de documentos por meio de algum tipo de } \\
\text { rede interna (ex.: intranet). }\end{array}$ & & & & & \\
\hline 9 & $\begin{array}{l}\text { A organização propicia ambientes informais para que os } \\
\text { indivíduos compartilhem conhecimentos e experiências entre } \\
\text { colegas de trabalho. }\end{array}$ & & & & & \\
\hline 10 & $\begin{array}{l}\text { A organização incentiva que os indivíduos compartilhem } \\
\text { sugestões no ambiente de trabalho. }\end{array}$ & & & & & \\
\hline 11 & A organização fomenta o trabalho em equipe. & & & & & \\
\hline 12 & $\begin{array}{l}\text { A organização incentiva que novas ideias e abordagens sobre } \\
\text { desempenho no trabalho sejam aplicadas no dia-a-dia. }\end{array}$ & & & & & \\
\hline 13 & $\begin{array}{lll}\text { A organização proporciona encontros para informar aos } \\
\text { indivíduos a respeito de inovações em suas atividades. }\end{array}$ & & & & & \\
\hline 14 & $\begin{array}{l}\text { A organização realiza mudanças de profissionais entre } \\
\text { departamentos e funções, proporcionando a participação do } \\
\text { indivíduo em outras equipes. }\end{array}$ & & & & & \\
\hline 15 & $\begin{array}{l}\text { A organização incentiva o rodízio de tarefas entre os profissionais } \\
\text { da organização. }\end{array}$ & & & & & \\
\hline 16 & $\begin{array}{l}\text { A organização informa seus integrantes a respeito de } \\
\text { responsabilidades de outros colegas de trabalho e departamentos. }\end{array}$ & & & & & \\
\hline
\end{tabular}




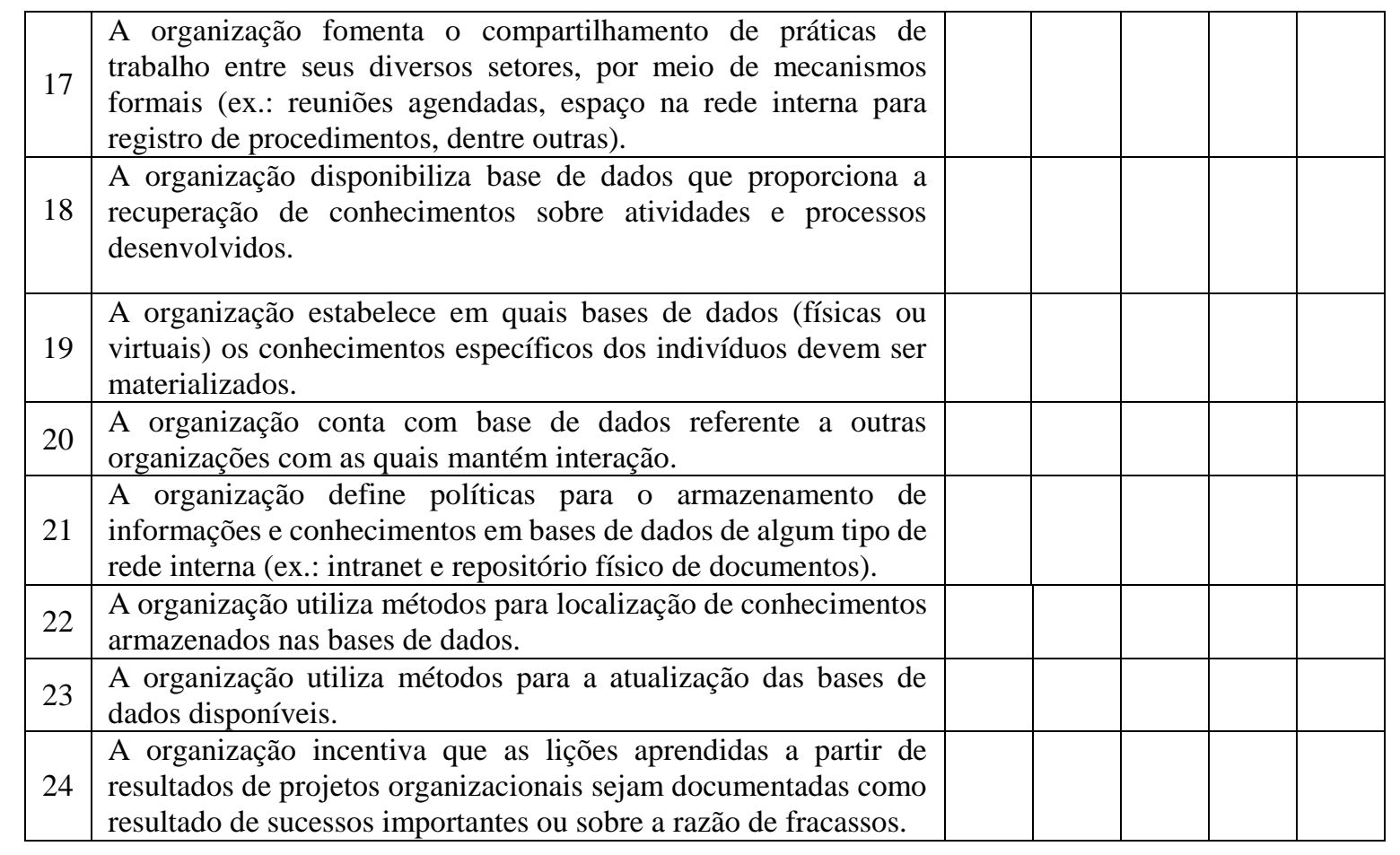

\section{PARTE II - AÇÃO DE INTERAÇÃO COM FONTES DE CONHECIMENTO}

Esta parte é composta por itens que abordam a sua interação com diferentes fontes de conhecimento da organização.

Assinale as assertivas, levando-se em consideração a escala de frequência abaixo.

\begin{tabular}{|c|c|c|c|c|}
\hline 1 & 2 & 3 & 4 & 5 \\
\hline Nunca ocorre & $\begin{array}{c}\text { Poucas vezes } \\
\text { ocorre }\end{array}$ & Às vezes ocorre & $\begin{array}{c}\text { Ocorre muitas } \\
\text { vezes }\end{array}$ & Sempre ocorre \\
\hline
\end{tabular}

\begin{tabular}{|c|l|l|c|c|c|}
\hline \multirow{2}{*}{$\mathrm{N}^{\mathbf{0}}$} & \multicolumn{1}{|c|}{ Assertiva } & \multicolumn{3}{|c|}{ Opções de Resposta } \\
\cline { 2 - 5 } 25 & $\begin{array}{l}\text { Mantenho interação com grupos ou redes de pessoas na } \\
\text { organização. }\end{array}$ & & & & \\
\hline 26 & $\begin{array}{l}\text { Participo de grupos ou redes de pessoas externos à organização } \\
\text { que possuem afinidade com a minha atividade profissional. }\end{array}$ & & & & \\
\hline 27 & $\begin{array}{l}\text { Mantenho contato com especialistas da organização com } \\
\text { conhecimento reconhecido em temas específicos. }\end{array}$ & & & & \\
\hline 28 & $\begin{array}{l}\text { Participo de programas de aprendizagem, tais como atividades } \\
\text { internas de capacitação, cursos e visitas técnicas a outras } \\
\text { organizações. }\end{array}$ & & & & \\
\hline 29 & $\begin{array}{l}\text { Utilizo o conhecimento adquirido nas atividades internas, (ex.: } \\
\text { ações de capacitação interna e reuniões de trabalho) para a } \\
\text { consecução de objetivos organizacionais. }\end{array}$ & & & \\
\hline 30 & \begin{tabular}{l} 
Desenvolvo minhas atividades na organização em equipe. \\
\hline
\end{tabular} & & & & \\
\hline
\end{tabular}




\begin{tabular}{|l|l|l|l|l|l|l|}
\hline 31 & $\begin{array}{l}\text { Converso com outros colegas sobre assuntos relacionados ao } \\
\text { trabalho em encontros casuais (ex.: por exemplo, intervalo do café } \\
\text { e confraternizações da organização). }\end{array}$ & & & & & \\
\hline 32 & $\begin{array}{l}\text { Utilizo o conhecimento fruto das conversas com meus colegas da } \\
\text { organização para a resolução de problemas do trabalho. }\end{array}$ & & & & \\
\hline 33 & $\begin{array}{l}\text { Compartilho conhecimento relacionado com as atividades que } \\
\text { realizo em reuniões de trabalho. }\end{array}$ & & & \\
\hline 34 & $\begin{array}{l}\text { Utilizo ambientes virtuais (ex.: e-mail, rede intranet e } \\
\text { teleconferência) para interação com colegas de trabalho. }\end{array}$ & & & \\
\hline 35 & $\begin{array}{l}\text { Desenvolvo novas ideias e conceitos por meio de diálogos com } \\
\text { colegas de trabalho. }\end{array}$ & & & \\
\hline 36 & $\begin{array}{l}\text { Assimilo conhecimentos por meio de observações, imitações ou } \\
\text { práticas de colegas de trabalho. }\end{array}$ & & & \\
\hline 37 & $\begin{array}{l}\text { Durante as atividades diárias exponho o meu conhecimento por } \\
\text { meio de analogias e exemplos. }\end{array}$ & & & & \\
\hline 38 & $\begin{array}{l}\text { Compartilho conhecimento com colegas de trabalho por meio de } \\
\text { documentos e/ou repositórios virtuais de documentos. }\end{array}$ & & & \\
\hline 39 & $\begin{array}{l}\text { Utilizo o conhecimento armazenado nas bases de dados físicas e } \\
\text { virtuais da organização. }\end{array}$ & & & & \\
\hline
\end{tabular}

\section{PARTE III - DADOS DEMOGRÁFICOS E FUNCIONAIS}

Os próximos campos possuem a finalidade de captar algumas características da amostra de respondentes.

40- Sexo:

( ) Masculino ( ) Feminino

41- Idade:

42- Nível de escolaridade:

( ) Técnico ( ) Graduação ( ) Especialização ( ) Mestrado ( ) Doutorado

43-Ministério:

44- Tempo no Ministério:

45-Secretaria ou Setor no Ministério:

46-Tipo de vínculo com a organização:

( ) Concursado de carreira

( ) Concursado temporário

( ) Contratado 
47-Função atual:

48-Tempo na atual função: 